
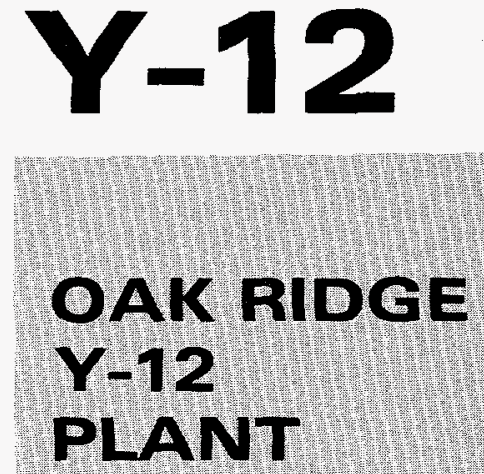

MARTH MARTETRA

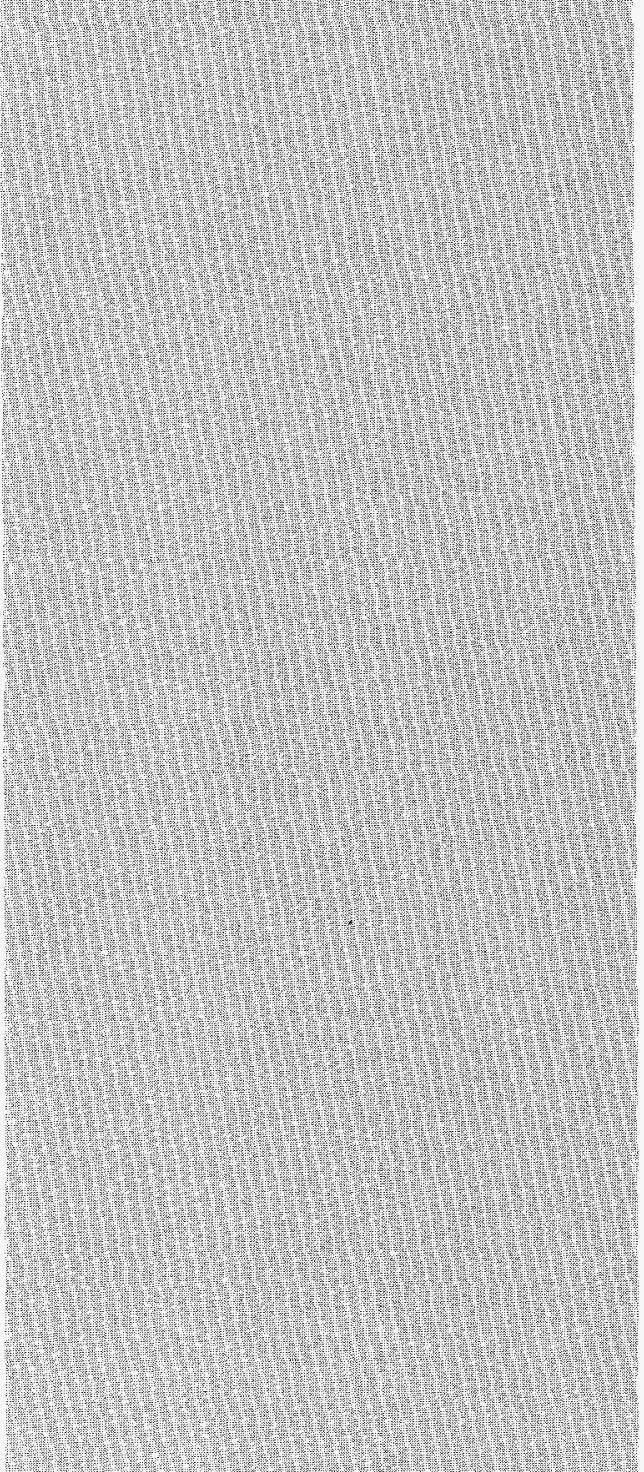

MANAGED BY

MARTIN MARIETTA ENERGY SYSTEMS, INC. FOR THE UNITED STATES DEPARTMENT OF ENERGY
INDEPENDENT REVIEW OF OAK RIDGE HCTW TEST PROGRAM AND DEVELOPMENT OF SEISMIC EVALUATION CRITERIA

May 1995
Prepared for the Center for Natural Phenomena Engineering Oak Ridge Y-12 Plant Oak Ridge, TN 37831-8169 operated by Lockheed Martin Energy Systems, Inc. for the

U. S. Department of Energy under contract DE-AC05-84OR21400 


\section{DISCLAIMER}

This report was prepared as an account of work sponsored by an agency of the United States Government. Neither the United States Government nor any agency thereof, nor any of their employees, makes any warranty, express or implied, or assumes any legal liability or responsibility for the accuracy, completeness, or usefulness of any information, apparatus, product, or process disclosed, or represents that its use would not infringe privately owned rights. Reference herein to any specific commercial product, process, or service by trade name, trademark, manufacturer, or otherwise, does not necessarily constitute or imply its endorsement, recommendation, or favoring by the United States Government or any agency thereof. The views and opinions of authors expressed herein do not necessarily state or reflect those of the United States Government or any agency thereof. 


\section{DISCLAMMER}

Portions of this document may be illegible in electronic image products. Images are produced from the best available original document. 


\title{
INDEPENDENT REVIEW OF OAK RIDGE HCTW TEST PROGRAM AND \\ DEVELOPMENT OF SEISMIC EVALUATION CRITERIA
}

May 1995

\author{
Prepared by \\ EQE International, Inc. \\ 18101 Von Karman Ave., Suite 400 \\ Irvine, CA 92715 \\ and \\ RPK Structural Mechanics Consulting \\ 18971 Villa Terrace \\ Yorba Linda, CA 92686
}

Prepared for the

Center for Natural Phenomena Engineering

Oak Ridge Y-12 Plant

Oak Ridge, TN 37831-8169

operated by

Lockheed Martin Energy Systems, Inc.

for the

U. S. Department of Energy

under contract DE-AC05-84OR21400 



\section{TABLE OF CONTENTS}

TABLE OF CONTENTS $\ldots \ldots \ldots \ldots \ldots \ldots \ldots \ldots \ldots \ldots \ldots$

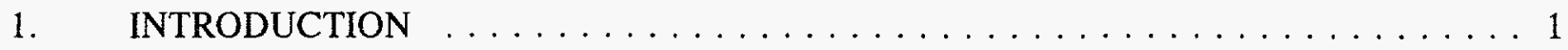

2. RECOMMENDED SEISMIC EVALUATION FOR UNREINFORCED HOLLOW CLAY TILE INFILL WALL CONSTRUCTION FOR OAK RIDGE Y-12 BUILDINGS . . . . . 3

2.1 EVALUATION OF DEMAND FOR HCTW BUILDINGS $\ldots \ldots \ldots \ldots \ldots$

2.1.1 Evaluation of Overall Seismic Response . . . . . . . . . . . . 3

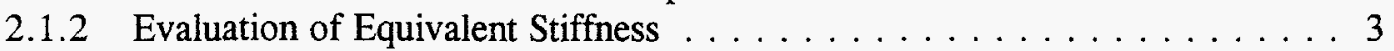

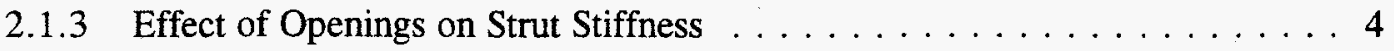

2.1.4 Evaluation of Out-of-Plane Demand on Infill Walls . . . . . . . . . . . 5

2.2 EVALUATION OF CAPACITIES FOR HCTW BUILDINGS . . . . . . . . 5

3. HCTW TEST PROGRAM ASSESSMENT $\ldots \ldots \ldots \ldots \ldots \ldots \ldots \ldots$

3.1 OAK RIDGE Y-12 BUILDING CONSTRUCTION (Y-12 BLDG. . . . . . . . 11

3.2 HCTW TEST PROGRAM $\ldots \ldots \ldots \ldots \ldots \ldots \ldots \ldots \ldots \ldots$

3.2.1 "Macro" Wall Tests (University of Tennessee) $\ldots \ldots \ldots \ldots \ldots \ldots$

3.2.1.1 In-Plane Testing $\ldots \ldots \ldots \ldots \ldots \ldots$

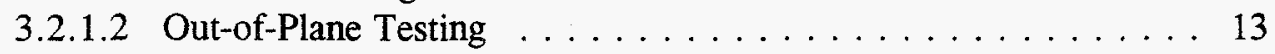

3.2 .2 "Full Scale" Wall Tests (Iowa State University) . . . . . . . . . . . . 13

3.2.2.1 In-Plane Testing $\ldots \ldots \ldots \ldots \ldots \ldots \ldots$

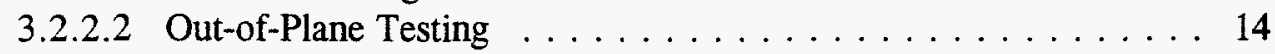

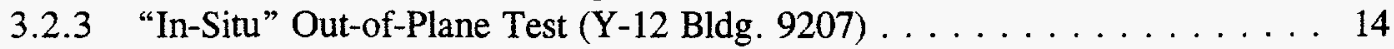

3.2 .4 Shake Table Test $($ CERL $) \ldots \ldots \ldots \ldots \ldots \ldots \ldots$

3.2.5 Masonry Component Tests (NIST, University of Tennessee, MMES) . . . 15

3.3 COMPARISON OF TEST WALL CONSTRUCTION AND Y-12 WALL

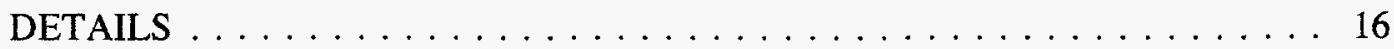

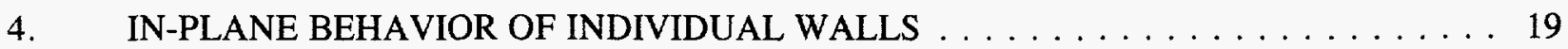

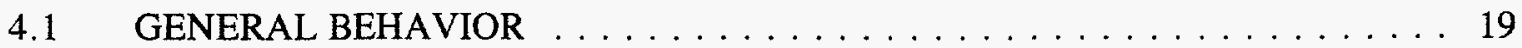

4.2 EVALUATION OF WALL LOAD CAPACITY AND ASSOCIATED LIMITING

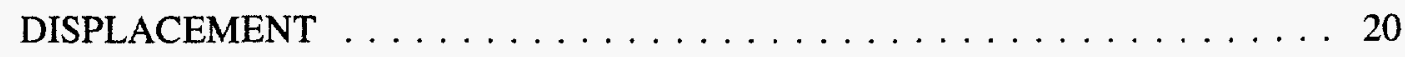

4.3 EQUIVALENT STRUT MODEL OF WALL STIFFNESS . . . . . . . . 21

4.4 EVALUATION OF FRAME MEMBERS AND CONNECTIONS $\ldots \ldots \ldots \ldots$

4.5 EQUIVALENT DAMPING FROM WALL LOAD-DISPLACEMENT

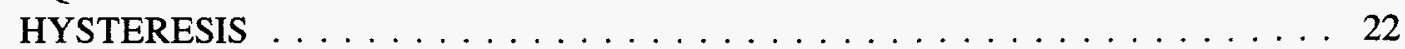

4.6 EFFECT OF OUT-OF-PLANE LOADS ON IN-PLANE WALL CAPACITY _ . 22

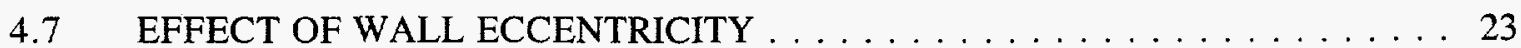

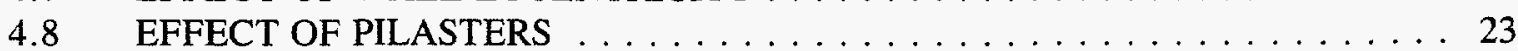

4.9 EFFECT OF COLUMN-WALL AND BEAM-WALL GAPS $\ldots \ldots \ldots \ldots$

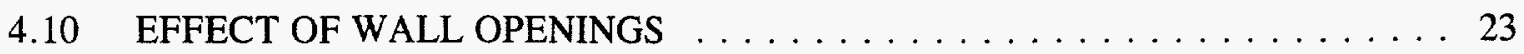

4.11 EFFECTS OF FRAME BEAM-COLUMN AND COLUMN BASE CONNECTION

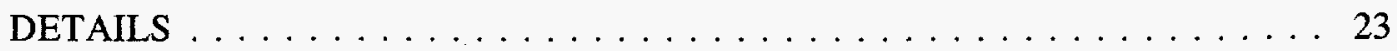

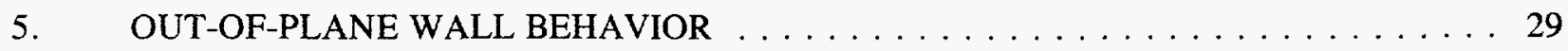

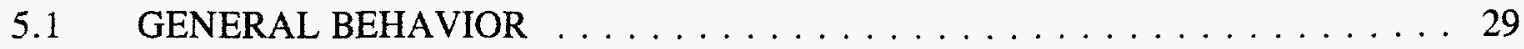

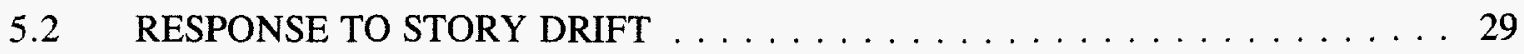

5.3 RESPONSE TO LATERAL OUT-OF-PLANE INERTIA LOADS . . . . . . . . . 29 
5.4 EVALUATION OF FRAME MEMBERS AND CONNECTIONS $\ldots \ldots \ldots \ldots$

5.5 EFFECT OF IN-PLANE LOADING ON OUT-OF-PLANE CAPACITY $\ldots \ldots$

6. EVALUATION OF DEMAND FOR HCTW BUILDINGS $\ldots \ldots \ldots \ldots \ldots \ldots$

6.1 GENERAL CONSIDERATIONS $\ldots \ldots \ldots \ldots \ldots \ldots \ldots \ldots \ldots \ldots$

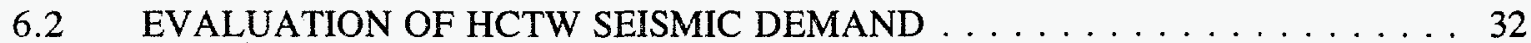

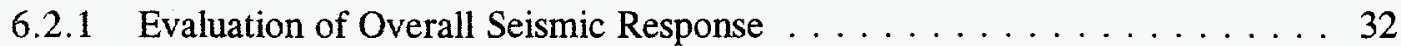

6.2 .2 Strut Properties . . . . . . . . . . . . . . . . . . . . 33

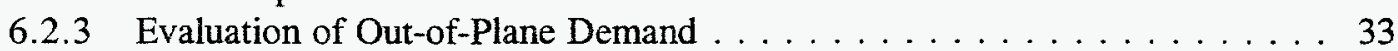

6.3 SEISMIC DEMAND OF HCTW INFILL WITH OPENINGS $\ldots \ldots \ldots \ldots \ldots$

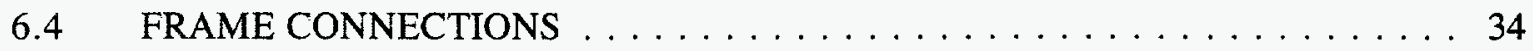

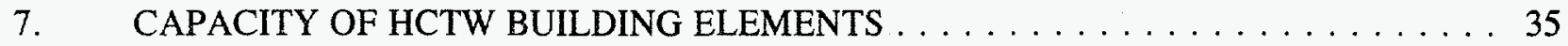

7.1 DOE SEISMIC CRITERIA BASED ON TARGET PERFORMANCE GOALS . . 35

7.2 IN-PLANE HCTW PANEL CAPACITY $\ldots \ldots \ldots \ldots \ldots \ldots \ldots$

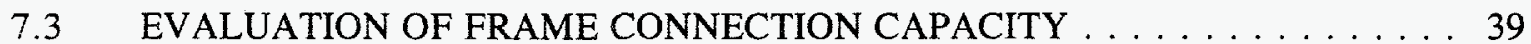

7.4 IN-PLANE HCTW LIMIT DISPLACEMENTS . . . . . . . . . . . . . . . . 39

7.5 OUT-OF-PLANE HCTW INERTIA CAPACITY \& LIMIT DISPLACEMENTS . 40

7.5 .1 Response to Out-of-Plane Inertia Loads . . . . . . . . . . . . . . . . 40

7.5.2 Out-of-Plane Response to Story Drift . . . . . . . . . . . . . . 41

7.6 IN-PLANE AND OUT-OF-PLANE INTERACTION $\ldots \ldots \ldots \ldots \ldots$

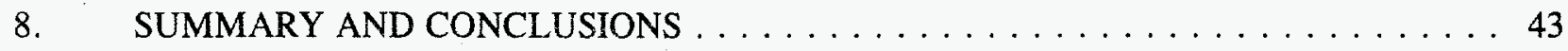

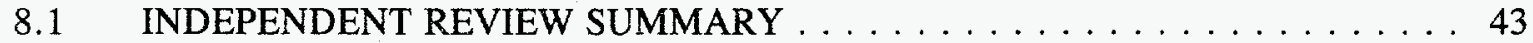

8.2 ASSESSMENT OF OAK RIDGE HCTW TEST PROGRAM $\ldots \ldots \ldots \ldots$

8.3 SUMMARY OF IN-PLANE TESTS AND EVALUATION $\ldots \ldots \ldots \ldots$

8.4 SUMMARY OF OUT-OF-PLANE TESTS AND EVALUATION $\ldots \ldots \ldots$

8.5 SEISMIC EVALUATION CRITERIA FOR HCTW BUILDINGS $\ldots \ldots \ldots$

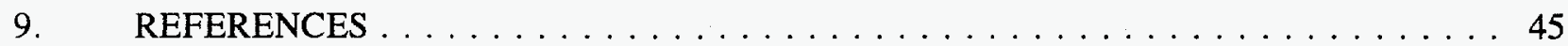

APPENDIX A: $\quad$ DETERMINATION OF MAXIMUM TEST DISPLACEMENT

ASSOCIATED WITH MAXIMUM LOADING . . . . . . . . . . . A A.1

APPENDIX B: $\quad$ EVALUATION OF EQUIVALENT VISCOUS DAMPING FOR

HYSTERETIC BEHAVIOR . . . . . . . . . . . . . . . B.1

APPENDIX C: $\quad$ EVALUATION OF OUT-OF-PLANE TEST CAPACITY $\ldots \ldots \ldots$ C.1 


\section{FIGURES}

2.1 Equivalent Diagonal Strut Representation of an Infill Wall $\ldots \ldots \ldots \ldots \ldots \ldots$

$2.2 \mathrm{HCTW} \quad$ Opening Cases $\ldots \ldots \ldots \ldots \ldots \ldots \ldots \ldots$

\section{TABLES}

2.1 Values for $\mathrm{C}$ for Simulating Nonlinear Wall Behavior $\ldots \ldots \ldots \ldots \ldots$

3.1 Summary of Masonry Prism Strength, $\mathrm{F}_{\mathrm{m}}^{\prime}$, Test Results $\ldots \ldots \ldots \ldots$

3.2 Summary of Masonry Prism Modulus, $E_{m}$, Test Results $\ldots \ldots \ldots \ldots$

4.1 In-Plane Net Horizontal Panel Test Capacities and Displacements . . . . . . . . . . 25

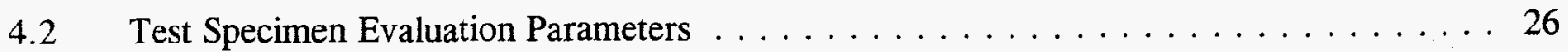

$4.3 \quad$ Regression of $\lambda$ vs. Test Capacity $/\left(\mathrm{t}_{\mathrm{x}} \mathrm{f}_{\mathrm{m}-\mathrm{eff}}\right) \ldots \ldots \ldots \ldots \ldots \ldots \ldots \ldots$

4.4 Comparison of Predicted Horizontal In-Plane Capacities with Test Results . . . . . . . 28 


\section{INTRODUCTION}

Many of the existing buildings at the Oak Ridge Y-12 Plant are steel frame construction with unreinforced hollow clay tile infill walls (HCTW). The composite action of the frame and HCTW infill provides some level of resistance to lateral loads such as those generated by earthquakes and wind. However, such construction is not permitted by current building codes for withstanding earthquake and wind loads. Therefore, an industry accepted method of evaluation for this type construction does not exist. In order to understand the behavior of HCTW construction at Oak Ridge, a testing and analysis program has been undertaken. An independent review of the testing and analysis program and development of recommended acceptance criteria has been performed and is documented in this report. The results of this effort are recommendations for Oak Ridge HCTW seismic criteria and the basis for the recommendations.

Natural phenomena hazard (NPH) design and evaluation criteria for DOE facilities are provided in DOE-STD-1020-94. In order to comply with the NPH mitigation requirements given in DOE 5480.28, seismic criteria for Oak Ridge HCTW construction must follow the intent and philosophy of DOE-STD1020-94. Elements of DOE-STD-1020-94 seismic criteria include: (1) Specification of earthquake loading; (2) Evaluation of seismic demand; (3) Specification of permissible capacity; (4) Detailing requirements; and (5) Peer review requirements. All of these elements include intentional conservatism based on the target performance goals from DOE 5480.28. Specification of earthquake loading and peer review requirements are common to all DOE facility construction and thus are independent of criteria for HCTW construction. Acceptance criteria for HCTW construction does require specific new requirements to be developed for evaluation of seismic demand, specification of permissible capacity, and detailing. These criteria must be developed with the same level of conservatism used for other types of construction per DOE-STD-1020-94.

Recommended seismic design and evaluation criteria for $\mathrm{Y}-12$ HCTW construction is presented in Section 2. Results of the peer review of the test program and analyses of the test results which provide bases for development of the criteria are presented in the remaining sections of this report. 



\section{RECOMMENDED SEISMIC EVALUATION CRITERIA FOR UNREINFORCED HOLLOW CLAY TILE INFILL WALL CONSTRUCTION FOR OAK RIDGE Y-12 BUILDINGS}

\subsection{EVALUATION OF DEMAND FOR HCTW BUILDINGS}

\subsubsection{Evaluation of Overall Seismic Response}

A dynamic model of the building should be developed for seismic analysis representing all beams and columns as beam elements and all infilled HCT panels as diagonal struts. An equivalent diagonal strut used to represent infill wall panels is illustrated in Figure 2-1. The panels may be represented either as a single strut or as 2 struts in an "X-bracing" configuration with each strut at $1 / 2$ the total wall stiffness in the analytical model. For the types of column base and beam-column connections found in Buildings 9212 and 9207 , assuming the connection to be an effective pin with zero moment capacity is recommended. It should be recognized that the equivalent strut approach has been formulated without consideration of vertical forces. Thus, vertical loads should be omitted during the lateral load analysis and superimposed onto frame members later.

Linear elastic seismic analyses may be performed using the response spectrum modal superposition method. Spectra in compliance with DOE-STD-1020-94 at 10 percent of critical damping should be used for evaluation of buildings where HCT infill walls are the lateral force resisting system.

\subsubsection{Evaluation of Equivalent Stiffness}

HCT walls exhibit nonlinear behavior during large seismic response as wall stiffness decreases with increasing wall displacement. The strut model may be formulated to provide wall stiffness associated with a given level of displacement. By such an approach, the effective strut stiffness, or the product of modulus times area $(E A)_{\text {eff }}$ of the equivalent strut is reduced by a parameter $(4 / C)$ as given by Equation $2-1$. The value of $c$ (minimum $=5$ for near elastic response levels and a maximum of 18 for response associated with the panel capacity) is a function of the secant stiffness from the wall load-deflection curve, as given in table $2-1$.

$$
(\mathrm{Ea})_{\mathrm{eff}}=\mathrm{E}_{\mathrm{m}}(4 / \mathrm{C}) \mathrm{wt}
$$

The width of the equivalent strut is then determined by :

$$
\mathrm{w}=\alpha / \cos \theta
$$

The length of column bearing on the infill is given by:

$$
\alpha=\pi / 4 \lambda
$$


where the parameter, $\lambda$, is given by:

$$
\lambda=\left(E_{m} t \sin 2 \theta /\left(4 E_{s} I_{c o l} h^{\prime}\right)\right)^{1 / 4}
$$

in which $E_{m}$ is the gross elastic modulus of the masonry (ksi); $E_{S} I_{c o l}$ is the flexural rigidity of the column $\left(\mathrm{ksi} \times \mathrm{in}^{4}\right) ; \theta$ is the slope of the infill diagonal to the horizontal; $\mathrm{t}$ is the infill gross thickness (inches); and $h^{\prime}$ is the infill height (inches). The gross elastic modulus of the HCTW, $E_{m}$, may be taken as 350 and 400 ksi for 8" and 13" walls, respectively. Eq. 2-3 is appropriate for frames with type 2 connections (zero moment). The effective length of column bearing contact, $\alpha$, should be limited to no more than 0.2 times wail height, $\mathrm{h}^{\prime}$.

For HCT infills offset from the framing centerline, use the full gross thickness, $t$, if the panel is totally enclosed in the framing. If part of the panel is outside the framing, use the gross thickness of the portion of the panel enclosed in the framing provided that at least one cell is enclosed. In this context, "framing" includes masonry pilasters. These rules for thickness, $t$, apply both to stiffness determination as described above and to capacity evaluation as described in the following section.

Estimates of building deformations are made to establish the secant stiffness for the equivalent strut. The resulting deformations from the response analysis must be compared to the estimated deformations and an iteration may be needed such that calculated and assumed displacements are sufficiently close that the building modal properties are consistent with the response.

\subsubsection{Effect of Openings on Strut Stiffness}

The presence of openings may significantly alter the in-plane stiffness and strength of HCTW panels. Several opening configurations are illustrated in figure 2-2. The approach employed to account for openings is to evaluate the stiffness and capacity of the panel without openings and then apply reduction factors for stiffness and strength as given below:

\begin{tabular}{|c|c|c|}
\hline Panel Case & Stiffness Reduction & Strength Reduction \\
\hline 1 & $100 \%$ & $100 \%$ \\
\hline 2 & $100 \%$ & $100 \%$ \\
\hline 3 & $75 \%$ & $50 \%$ \\
\hline 4 & $75 \%$ & $75 \%$ \\
\hline 5 & $75 \%$ & $50 \%$ \\
\hline 6 & $75 \%$ & $50 \%$ \\
\hline
\end{tabular}


The rules for panel cases 1 and 2 apply if the door openings are approximately in the middle one-third of the panel width. For panel cases 5 and 6 , the strut model should be on a diagonal across the solid portion of the panel (e.g., partial height panel modeled with partial height strut).

\subsubsection{Evaluation of Out of Plane Demand on Infill Walls}

The overall seismic response analysis gives out-of-plane displacements and accelerations at model node points. The out-of-plane displacements may be used to compute story drifts which may be compared to story drift limits. The out-of-plane accelerations may be used to develop seismic inertial loads on the wall by separate calculations. It is recommended that out-of-plane wall demand be determined as the inertial load corresponding to the peak spectral acceleration from the ground response spectrum increased by an amplification factor of 2 . If the demand obtained in this conservative manner, exceeds out-of-plane wall capacity, the demand should be determined in a more realistic manner from floor spectral accelerations at the wall out-of-plane natural frequency.

If the out-of-plane demand is less than $1 / 2$ the out-of-plane capacity, interaction with in-plane behavior need not be considered. Where interaction is considered, a linear interaction relation shall be used. Note that when out-of-plane and in-plane demands are combined, it should be done in a probabilistic manner such as the 100-40-40 rule per ASCE 4-86.

\subsection{EVALUATION OF CAPACITIES FOR HCTW BUILDINGS}

Acceptance criteria for unreinforced infilled HCTW at Oak Ridge have been developed based on the target performance goals of DOE 5480.28. It is recommended that horizontal in-plane HCTW panel capacity be determined from:

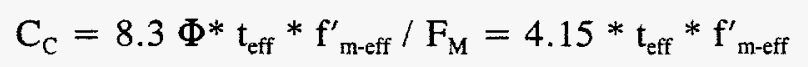

where $\Phi$ is a strength reduction factor equal to $2 / 3, \mathrm{f}^{\prime}$ m-eff is the geometric average of the median masonry strength normal and parallel to the cells in the masonry units, $F_{M}$ is a factor of safety on the median masonry strength equal to $4 / 3$, and $t_{\text {eff }}$ is the thickness of the wall which does not protrude out from the frame members. The value given above is the capacity of the HCTW panel only. For those cases where the frame has moment connections, the capacity of the frame may be computed from its stiffness times the response displacement and added to the above capacity to produce the total capacity of the infill HCTW element. For $\mathrm{Y}-12$ construction, $\mathrm{f}_{\mathrm{m} \text {-eff }}^{\prime}$ values of 647 psi for 8 inch walls and 420 psi for 13 inch walls are recommended. 
Frame connections (column base and beam-column) shall be required to take the full level of force in the strut representing the wall ignoring any friction between the wall and the frame in accordance with DOE-STD-1020-94 for the appropriate materials of construction taking $F_{\mu}$ to be unity.

For Performance Category 3 , in-plane horizontal displacement of walls shall be limited to 0.5 inches to be consistent with the performance goals for this category. For buildings in Performance Category 1 or 2 , in-plane horizontal displacement is permitted out to 0.75 inches provided that maximum load is limited to $75 \%$ of the level given by Equation 2-5. If maximum load per Equation 2-5 is reached in a wall element prior to reaching the maximum limit displacement, it is permissible to reduce the stiffness of that element by some rational approach and re-run the demand calculation allowing redistribution of loads to other elements. The limit state is reached when the element reaches the limit displacement or other elements are not able to resist the increased loads from the redistribution.

The out-of-plane capacity for inertial seismic loads may be estimated from the prediction equation presented in Equation 2-6.

$$
q=0.8 * \Phi *\left(f_{m}^{\prime} / F_{M}\right)^{0.75} * t^{2} * \beta / h^{\prime 2.5} \leq 3 p s i
$$

where $\mathrm{q}$ is the uniform out-of plane pressure capacity in psi of a wall which is primarily acting in one way action spanning vertically, $\Phi=2 / 3, \mathrm{~F}_{\mathrm{M}}=4 / 3, \mathrm{f}_{\mathrm{m}}{ }_{\mathrm{m}}$ is the median masonry prism strength normal to the masonry unit cells in psi, $t$ is the infill gross thickness in inches, $h^{\prime}$ is the infill height in inches, and $\beta$ is a measure of the relative stiffness of the bounding beam. The term for horizontal arching can be used if there is a mechanism to prevent slippage of the wall along the column.

Out-of-plane response to story drift is expected to be governed by the story drift limits from DOESTD-1020-94 for buildings. 
Table 2.1. Values of $\mathbf{C}$ for Simulating Nonlinear Wall Behavior

\begin{tabular}{|c|c|c|}
\hline Displacement (in) & C & Typical Infill Damage \\
\hline $0.0-0.05$ & 5 & None \\
\hline $0.05-0.2$ & 7 & Diagonal Mortar Joint Cracking \\
\hline $0.2-0.4$ & $\begin{array}{l}1 \\
1 \\
\end{array}$ & Off Diagonal Mortar Joint Cracking \\
\hline $0.4-0.6$ & $\begin{array}{l}1 \\
4\end{array}$ & Banded Diagonal Mortar Joint Cracking \\
\hline $0.6-0.8$ & $\begin{array}{l}1 \\
6 \\
\end{array}$ & Corner Mortar Crushing and Tile Cracking \\
\hline $0.8-1.0$ & $\begin{array}{l}1 \\
8\end{array}$ & Tile Faceshell Splitting (Primarily Corner Regions) \\
\hline $\begin{array}{c}\text { 1.5xDisplaceme } \\
\text { nt @ Ultimate }\end{array}$ & & Tile Faceshell Spalling \\
\hline
\end{tabular}




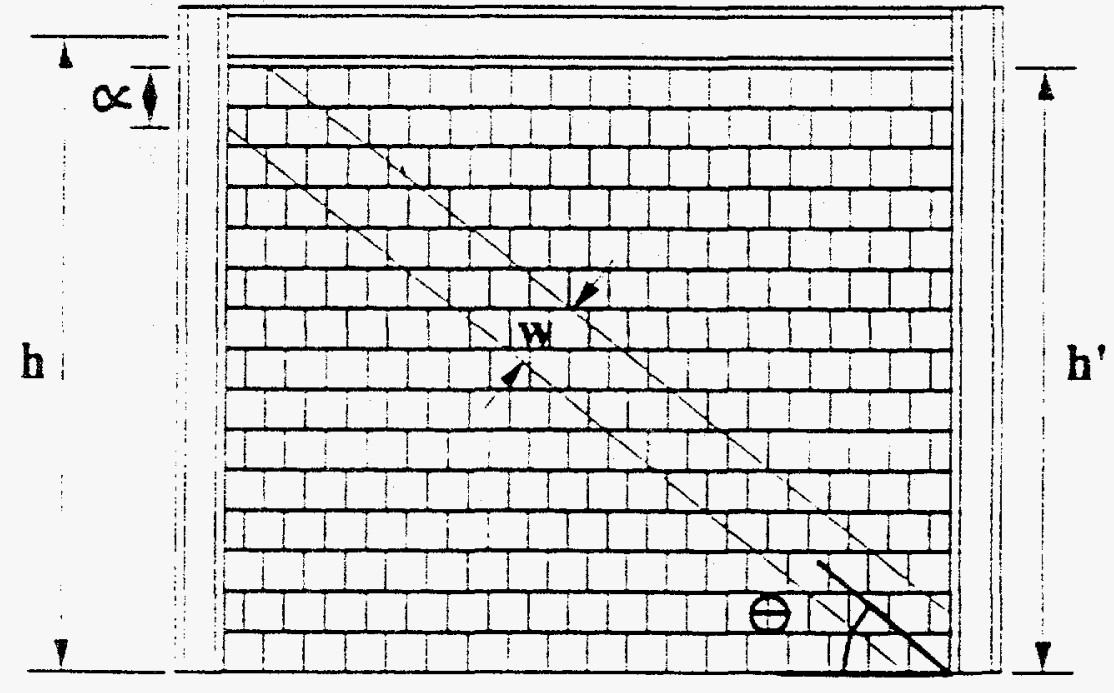

Fig. 2.1. Equivalent diagonal strut representation of an infill wall 

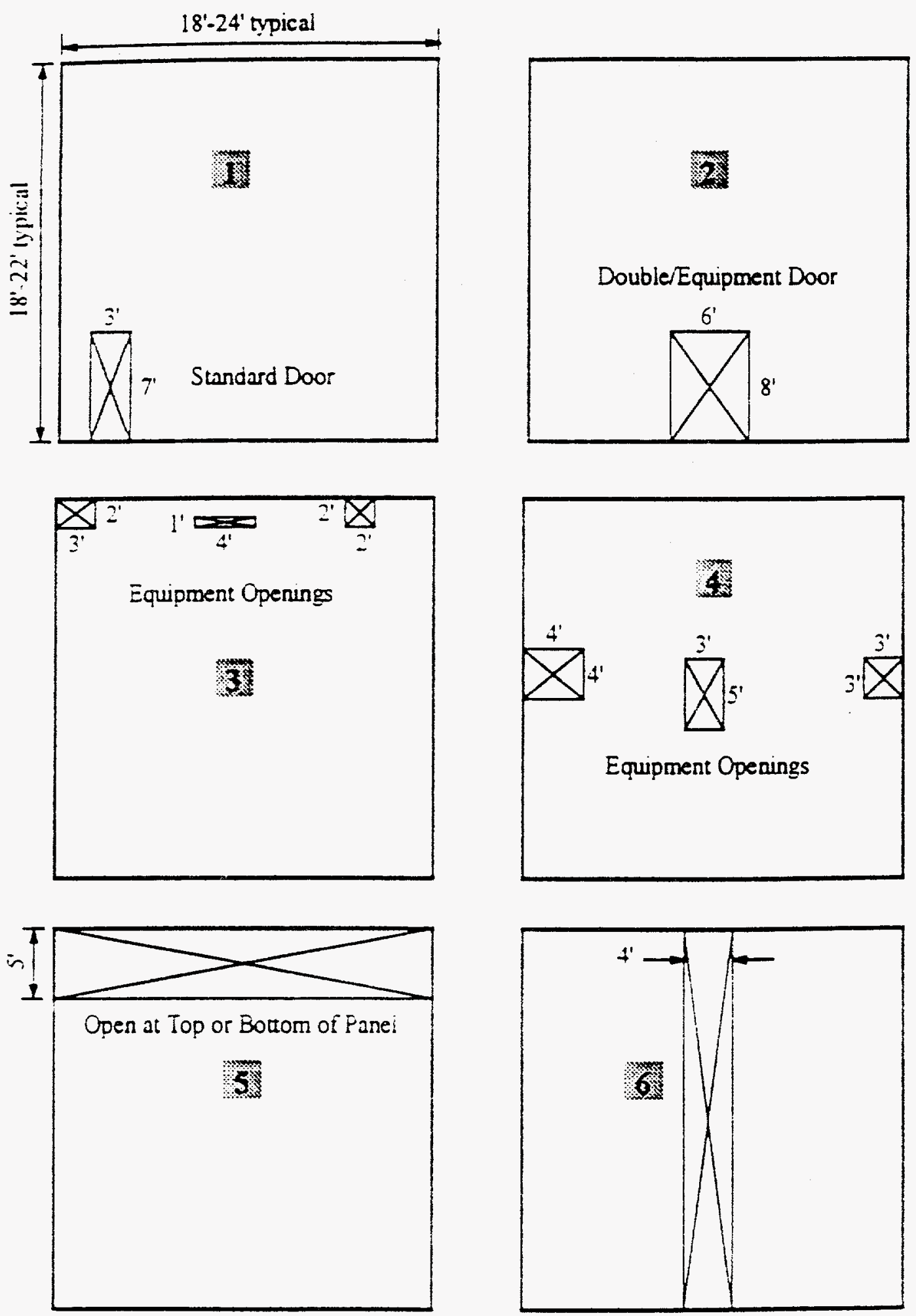

Fig. 2.2. HCTW opening cases 



\section{HCTW TEST PROGRAM ASSESSMENT}

\subsection{OAK RIDGE Y-12 BUILDING CONSTRUCTION (Y-12 BLDG. 9212 \& 9207)}

References $47 \mathrm{a}, 47 \mathrm{~b}$, and 50 were provided for review. These documents provide a general overview of the construction of Buildings 9212 and 9207 . Additional information on wall and frame details was obtained from References 9 and 16. Y-12 buildings were constructed in the late 1940s and early 1950s without explicit seismic design consideration. The 9212 Drawings (Ref. 47b) indicate that a wind loading of 15 psf was considered. These structures are steel frames infilled with HCT walls which are of the sideconstruction type (cells horizontal) using 4 in. and 8 in. HCT units in either single-wythe or double-wythe arrangement. The walls are predominantly 8 and 13 in. nominal thickness. Double-wythe 13 in. walls have a Y-12 specific configuration with the position of the 8 in. and 4 in. HCT units alternating from course to course in a running bond pattern with the headjoints staggered by half of a tile. A continuous bed joint (nominal 1/2 in.) is utilized between each course and a full head joint (nominal 3/8 in.) exists between tiles, however a cavity exists (void collar joint) between wythes which alternates position from course to course. There was no attempt to fill the collar joint with mortar during construction. This unique configuration with discontinuous collar joints is not typical of commercial infill construction used elsewhere during the $1940 \mathrm{~s}$ and $1950 \mathrm{~s}$. Wall-frame interfaces are typically grouted such that the wall is confined by the frame without gaps. Columns are, in some cases, enclosed by masonry and mortar to form pilasters.

Steel frames are A7 steel with riveted joints between the beams and columns. All frame connections are either 1950 s vintage AISC "Series B" standard beam connections or top and seat angle beam seats utilizing $3 / 4$ in. rivets in 13/16 in. holes. In accordance with current AISC guidelines, these framing connections would be denoted as Type 2 connections. Typical column base connections are double clip angles, each riveted to the column web on one leg and attached to a column anchor bolt on the other leg.

\subsection{HCTW TEST PROGRAM}

The initial planning of the HCTW evaluation program is presented in Reference 39. This plan was detailed and complete including the in-plane and out-of-plane testing of "macro" scale and full scale laboratory frames with HCT infill. In-situ testing of actual Y-12 walls was included as well as in-situ material characterization tests to define the condition and strength of existing Y-12 construction. Laboratory testing of masonry components was planned and the full inter-relationship of the various test program elements was outlined for the ultimate goal of developing new and correlating existing predictive 
analysis methods developed for using HCT masonry infill construction as lateral force resisting elements in the seismic evaluation of existing $\mathrm{Y}-12$ buildings. An Expert Review Committee of independent consultants, involved with masonry research and seismic evaluation of existing buildings with masonry construction, was utilized five times during the conduct of the program to review progress and make recommendations (Reference 15) on requested program issues. Test plans were prepared for the conduct of all tests (References 17-38) which included specimen dimensions, construction specifications, location of instrumentation, instrumentation calibration procedures, data acquisition parameters, check and data sheets, and general test procedure to be followed. In general, all LMES QA procedures were satisfied or waivers provided for deviations. The tests were performed according to procedure and the data obtained was of high quality. Test documentation has been, in general, in the form of academic thesis (MS) or dissertations $(\mathrm{PhD})$ prepared by the individuals involved in the program. It should be noted that this form of documentation is automatically peer reviewed by the academic reviewing committee. Tests performed at the Y-12 facility and by other contractors have been completely documented as have several professional papers as LMES reports. All documentation is of high quality.

While all testing has been extensively documented, the program plan was never updated or summarized. Thus, the changes in planning and the cross-referencing of the various final test results of the program are not documented. This has made the peer review somewhat of a forensic exercise to determine what tests were conducted and which report documented the results. Often an applicable report was found by reference in another report under review. In some respects, this report serves as a summary program plan. This criticism is, of course, not technical in nature and should not detract from the high technical quality of the work performed in the program.

\subsection{1 "Macro" Wall Tests (University of Tennessee)}

The test results for this set of tests, conducted on panels limited to a height of $88 \mathrm{in}$., are contained in Reference 46 with supplementary information in Refs. 2, 6, 8, and 9. The test setups were sized to be large enough to obtain data on the interaction of framing and full sized masonry units for the purpose of correlation to known predictive relations on masonry behavior. The test specimens are approximately one third to one-half of the height of comparable Y-12 walls. All panels, except one, had columns oriented such that the column web would bear on the masonry wall during in-plane loading (weak axis flexure of the column). The single exception test had the column flange bearing on the masonry wall during in-plane loading (strong axis flexure orientation of the column). All the steel frames were fixed at the base (welded to anchored base plates) and all beam/column connections were double clip angles connecting the beam web to the column web (weak axis flexure) or flange (strong axis flexure). All beam/column connections were bolted and designed as slip-critical (friction) connections using A-325 bolts. 


\subsubsection{In-Plane Testing}

Eleven steel frames infilled with clay tile (side construction only) were tested to failure with inplane loading only. Each specimen had a different geometric or construction parameter varied for the purpose of assessing the sensitivity of the particular parameter on structural behavior. Two walls were repaired and retested for a total of thirteen tests with in-plane loading only.

The in-plane loading was applied under displacement control. During each loading step, the displacement of the frame/wall was increased in increments and then reverse cycled for two or three cycles at the new constant displacement. Data for all instrumentation was continuously acquired during the conduct of a test. The bare frame was tested after wall failure at the maximum displacement associated with the peak frame/wall loading to establish the "frame only" load.

Four additional tests were conducted with out-of-plane loading prior to in-plane testing. Two of these tests considered out-of-plane drift (imposed displacement only) prior to in-plane loading and two tests walls to out-of-plane lateral loading (air bag) prior to in-plane loading. Three of these tests are referred to in Ref. 46 as sequential loading tests and the fourth was called a combined load test, however, for the combined load test, the pressure loading was applied while the in-plane loading was maintained, but the pressure load was equal to zero during an incremental increase of in-plane loading.

\subsubsection{Out-of-Plane Testing}

Three steel frames with infills, each with a different wall thickness, were tested to failure with outof-plane pressure (air bag) loading only and a fourth frame/wall was first subjected to in-plane loading and then tested to failure with out-of-plane pressure loading. The pressure loading was applied under load control, with linear increasing pressure and approximately two load-unload cycles at each increment of pressure loading. Test pressure was decreased after the maximum load point was reached and wall displacement was increasing at a higher rate.

\subsection{2 "Full-Scale" Wall Tests (Iowa State University)}

The test results for these tests are contained in Reference 16. Two full-scale frames with 13 in. thick infilled walls, $24 \mathrm{ft}$. wide and $21 \mathrm{ft}$. high (dimensions of wall enclosed within the frame), were constructed to reflect the actual steel framing details and side construction masonry details of the perimeter walls of the Y-12 Building 9212 wings, including pilasters ( $25 \mathrm{in}$.) and wall offset ( 3 in. of the 13 in. wall were not enclosed by the $10 \mathrm{in}$. column). The actual wall test specimens included a $2 \mathrm{ft}$. parapet above the 
confining beam and approximately $1.5 \mathrm{ft}$. additional wall construction (unconfined) outside the pilasters on either side of the test specimen. The column base connection was designed to act as an effective pin and the beam/column connection reflected the eccentricity and details of the actual Building 9212 frame connection, except that A325 bolts were utilized and installed as slip-critical (friction) bolts.

\subsubsection{In-Plane Testing}

Both walls, with identical construction, were subjected to in-plane loading until failure. One wall was subjected to out-of-plane drift loading prior to the in-plane loading and the other wall was unstressed prior to in-plane loading. The in-plane loading was applied under displacement control, with the reverse cycling displacement increasing at a linear rate during the test period.

\subsubsection{Out-of-Plane Testing}

Out-of-plane loading was limited to imposed cyclic drift (simulated diaphragm displacement) only. No lateral pressure loading of the wall was conducted. The bare frame was also tested for this drift loading only.

\subsection{3 "In-Situ" Out-of-Plane Test (Y-12 Bldg. 9207)}

In this test, an actual wall ( 8 in. thick, $28 \mathrm{ft}$. long, and $12 \mathrm{ft}$. high) in the first story of Building 9207 was tested using a lateral loading imposed by an air bag. The test was conducted under load control with the air pressure gradually increasing until the wall displacements continued to increase without a corresponding increase in pressure. This test is completely documented in Reference 50 with supplementary information in Refs. 48 and 49. Reference 51 present an extensive pretest analysis of the wall behavior.

\subsubsection{Shake Table Tests (CERL)}

A $10 \mathrm{ft}$. by $11 \mathrm{ft}$. plan and $8 \mathrm{ft}$. high frame structure with two infill walls $11 \mathrm{ft}$. by $8 \mathrm{ft}$. was constructed on the CERL shake table and subjected to various levels of table motion. It should be noted that the in-plane frame and walls were approximately the same size as used in one of the "macro-wall" tests (Test 17). A $10 \mathrm{ft}$. $\times 11 \mathrm{ft} . \times 8 \mathrm{in}$. concrete slab was attached to the top of the frame (columns) to simulate a roof or floor slab mass. Reference 45 provides a summary overview of the testing conducted. The biaxial CERL table was only driven in the uniaxial horizontal direction during the test program. The input motion was the Oak Ridge site specific earthquake time history (approx. $10 \mathrm{sec}$. strong duration). The structure 
was first tested for table input motion in the out-of-plane direction of the walls and then rotated and subjected to table input motion in the in-plane direction of the walls. In each direction, the structure was progressively subjected to factored input motion with a low level random motion test between each earthquake motion to assess the changes in structure frequency. The maximum out-of-plane input motion was $4 \mathrm{x}$ the reference site specific motion and the maximum in-plane input was $16 \mathrm{x}$ the reference motion. After the conclusion of the earthquake motion tests, the structure was subjected to an in-plane $1.0 \mathrm{~g}$ sine sweep motion from 10 to $20 \mathrm{~Hz}$, followed by a $3.0 \mathrm{~g}$ sine sweep decreasing from $15 \mathrm{~Hz}$. Wall failure occurred at $12.7 \mathrm{~Hz}$ during this $3.0 \mathrm{~g}$ sine sweep.

\subsubsection{Masonry Component Tests (NIST, University of Tennessee, LMES)}

Refs. 7, 41, 44, and 67 contain descriptions of the testing performed on tile masonry units. Ref. 67 also summarizes the characterization of mortar used in Y-12 construction. The ultimate masonry assemblage strength, $\mathrm{f}_{\mathrm{m}}$, for the test walls, as obtained from prism ( $2 \mathrm{ft} . \times 4 \mathrm{ft}$.) tests, are documented in Refs. 63 and 64 with supplementary data in Ref. 8, 9, 16, 44, 45, and 46. Both Refs. 63 (NIST) and 64 (UT/LMES) report the strength of 8 in. and 13 in. wall prisms (side construction) for loading parallel and normal to the HCT cells as summarized in Table 3-1.

The tests performed by NIST (and documented in Ref. 63) can be divided into three subgroups: Task 1, Task 2: Groups 1\&3, and Task 2: Group 2. Task 1 was a set of six preliminary prism tests conducted to check specimen construction and test procedures. Task 2 was a set of 41 additional prisms of which 28 prisms were constructed by NIST personnel (Groups $1 \& 3$ ) and the remainder constructed by an outside mason contractor (Group 2). The tests conducted by UT/LMES (and documented in Ref. 64) consisted of 22 prisms which were constructed by the same masons used to fabricate the macro-wall test specimens at UT.

A statistical evaluation of the entire set of NIST and UT prism tests indicates that the test strength, $\mathrm{f}_{\mathrm{m}}$, for loading parallel to the HCT cells (both 8 " and 13" wall thickness) is characterized by three distinct samples (NIST-Groups 1\&3; NIST-Group 2; and UT) of prism strength. The test strength for loading normal to the HCT cells (both 8 " and 13" wall thickness) is more similar from all tests with the samples from UT being distinct from the NIST test results for all groups. The COV of strength within each sample is within the range $0.02-0.23$, with 0.20 being considered as a representative upper bound to the COV for prism strength. The selection of appropriate values of wall strength to be used in the evaluation of Y-12 facilities is discussed in Section 7.

The prism test programs (NIST and UT) also acquired data to determine the elastic moduli for the wall prisms. Specifically, the median modulus, $\mathrm{E}_{\mathrm{m}}$, defined as the average slope of the prism test stress- 
strain diagram between $5 \%-50 \%$ of ultimate prism strength, was determined for each prism and reported in Refs. 63 and 64. The elastic moduli for loading parallel and normal to the HCT cells is summarized in Table 3-2. The moduli for the 8 " normal loading and both the $13^{\prime \prime}$ parallel and normal loading are characterized by two distinct samples (NIST and UT) of elastic modulus while the moduli for the 8 " parallel loading is represented by three distinct sample samples (NIST-Groups 1\&3; NIST-Group 2; and UT) of elastic modulus. A COV value of 0.30 is considered to be a representative upper bound to COV for elastic modulus.

\subsection{COMPARISON OF TEST WALL CONSTRUCTION AND Y-12 WALL DETAILS}

All of the test wall specimens utilized side construction using 4 in. and 8 in. HCT units with masonry details similar to Y-12 walls. Steel frame details were similar to the flexible Type 2 connections used in Y-12 buildings, however, the test frames used A325 bolts in slip-critical connections while the Y-12 framing has riveted connections. All of the "macro" wall tests, which were conducted for the purpose of assessing infill wall behavior, had wall height that was less than typical Y-12 walls. The full scale wall tests attempted to duplicate an actual Building 9212 wall in all respects including the pilaster detail which effectively embeds the steel column within the wall. 
Table 3.1. Summary of Masonry Prism Strength, $F_{m}^{\prime}$, Test Results

\begin{tabular}{|c|c|c|c|c|}
\hline \multirow{2}{*}{$\begin{array}{l}\text { Test } \\
\text { Group }\end{array}$} & \multicolumn{2}{|c|}{ 8" Thick Prisms } & \multicolumn{2}{|c|}{$13^{n}$ Thick Prisms } \\
\hline & Parallel & Normal & Parallel & Normal \\
\hline UT & 436 & 810 & 372 & 332 \\
\hline (mason familiar with $\mathrm{Y}-12$ ) & $(0.18)$ & $(0.09)$ & $(0.20)$ & $(0.23)$ \\
\hline NIST Task 1 & 799 & 1099 & 730 & 401 \\
\hline $\begin{array}{l}\text { NIST-Group } 1 \& 3 \\
\text { (constructed by NIST personnel) }\end{array}$ & 765 & 1073 & 897 & 452 \\
\hline NIST-Group 2 & 512 & 957 & 591 & 400 \\
\hline (constructed by outside mason) & $(0.08)$ & $(0.12)$ & $(0.16)$ & $(0.02)$ \\
\hline All NIST & 722 & 1017 & 793 & 435 \\
\hline NIST-Group 2 and UT & 474 & 883 & 481 & 366 \\
\hline & $(0.16)$ & $(0.12)$ & $(0.17)$ & $(0.18)$ \\
\hline
\end{tabular}

Values of ${f^{\prime}}_{m}$ are given in psi. The coefficient of variation is given in parentheses. 
Table 3-2. Summary of Masonry Prism Modulus, $\mathrm{E}_{\mathrm{m}}$, Test Results

\begin{tabular}{|c|c|c|c|c|}
\hline Test & $8^{\mathrm{N} T} \mathrm{~T}$ & isms & $13^{\prime \prime}$ & ms \\
\hline Group & Parallel & Normal & Parallel & Normal \\
\hline $\begin{array}{c}\text { UT } \\
\text { (mason familiar with } \mathrm{Y}-12 \text { ) }\end{array}$ & 329 & 768 & 410 & 730 \\
\hline $\begin{array}{c}\text { NIST-Group } 1 \& 3 \\
\text { (constructed by NIST } \\
\text { personnel) }\end{array}$ & 576 & 909 & 614 & 1045 \\
\hline $\begin{array}{c}\text { NIST-Group } 2 \\
\text { (constructed by outside mason) }\end{array}$ & 283 & 830 & 763 & 1135 \\
\hline All NIST & 531 & 866 & 660 & 1036 \\
\hline
\end{tabular}

Values of $E_{m}$ are given in ksi. 


\section{IN-PLANE BEHAVIOR OF INDIVIDUAL WALLS}

\subsection{GENERAL BEHAVIOR}

Holmes (Ref. 54) quotes J. R. Benjamin's observation (1957) on testing of infilled frames as, "Numerous studies were made involving exact mathematical procedures. The results were in no way better or more reliable than the most elementary procedures of strength of materials." Holmes then proposes the use of an equivalent compression strut to assess the behavior of masonry infilled frames. Stafford-Smith (Ref. 58) further develops this concept and then with Carter (Ref. 60) details a simple model based on a beam on an elastic foundation to represent the contact between the wall and the column. References 16 and 46 consider other approaches (Refs. $56 \& 60$ ) to assess the capacity of an infilled wall, however, Ref. 46 concludes that a modification of the Holmes and Stafford-Smith \& Carter approach provides a reasonable estimate of infilled frame stiffness and capacity when compared to the test data for HCT infilled frames. This method focuses on the interaction between the wall and the column as the infilled frame is loaded by a horizontal load applied at the top of the frame (simulating the lateral seismic in-plane load transferred by the floor or roof diaphragm to the infilled frame. The contact length for a semi-infinite beam (the column) on an elastic foundation (the masonry infill ) with a concentrated end loading, is used to define a bearing area (contact length $\mathrm{x}$ wall thickness) over which the horizontal average thrust component of the wall is distributed. The maximum lateral load is then the effective bearing area times the compressive strength of the masonry. Considering this horizontal capacity as a component of the diagonal reaction force imposed on the frame by the wall, the concept of an effective diagonal strut may be invoked as illustrated in Figure 2-1. The width of the effective compression strut, $w$, can be defined in terms of the panel geometry and the contact length, $\alpha$. The characteristic parameter for the column bearing on an elastic foundation, $\lambda$, is as given by Stafford-Smith and Carter (Ref. 60):

$$
\lambda=\left(\mathrm{E}_{\mathrm{m}}^{\mathrm{t}} \sin 2 /\left(4 \mathrm{E}_{\mathrm{s}} \mathrm{I}_{\mathrm{co}} \mathrm{h}^{\prime}\right)\right)^{1 / 4}
$$

in which $\mathrm{E}_{\mathrm{m}}$ is the gross elastic modulus of the masonry (ksi); $\mathrm{E}_{\mathrm{S}} \mathrm{I}_{\mathrm{co}} \mathrm{I}$ is the flexural rigidity of the column (ksi $x$ in $^{4}$ ); is the slope of the infill diagonal to the horizontal; $t$ is the infill gross thickness (inches); and $h^{\prime}$ is the infill height (inches).

The length of column bearing on the infill is given by Ref. 46 as

$$
\alpha=\pi / 4 \lambda
$$

It should be noted that Eq. 4-2 differs from the Stafford-Smith and Carter (Ref. 60) presentation which is based on full moment frame continuity. Eq. 4-2 is appropriate for frames with Type 2 connections (zero moment). 
The width of the equivalent strut is then determined by :

$\mathrm{w}=\alpha / \cos$

This equivalent strut formulation, based on elasticity parameters, has been noted by Wood (Ref. 61) to be inconsistent with capacity evaluation since the actual failure modes observed for infills are associated with plastic crushing of the infill in the corner of the frame. Wood does, however, consider the use of the equivalent strut formulation to be appropriate for deflection and stiffness estimates for infill frames.

\subsection{EVALUATION OF WALL LOAD CAPACITY AND ASSOCIATED LIMITING DISPLACEMENT}

As noted in Section 2, nineteen in-plane tests were conducted under the HCTW Program $\{17$ - UT (Ref. 46) and 2 - ISU (Ref. 16)\}. Both Refs. 16 and 46 utilize the maximum load (peak) and associated displacement obtained during cyclic testing of a specimen as the capacity of the specimen. We feel that the average load and displacement (average of push and pull) obtained during the peak loading cycle is the appropriate capacity and associated displacement that should be assigned to a given test (Appendix A). The net horizontal in-plane wall loads (i.e., wall only; the frame test stiffness times displacement has been subtracted from the test loads ) are compared in Table 4-1 for all nineteen tests. The numbered tests are those conducted at UT while the tests denoted W1 \& W2 are the two full-scale ISU tests. The shaded tests represent special boundary conditions or loading combinations (test 10a had an intentional 1 inch gap between the wall and the column; test $10 \mathrm{~b}$ was specimen $10 \mathrm{a}$ with corner damage repaired using concrete masonry; test $21 \mathrm{~b}$ was specimen $21 \mathrm{a}$ repaired after failure with new HCT units in the upper courses; test 24 had an opening in one corner; and test 23 was the "combined" loading test). Table 4-2 provides a tabulation of test specimen evaluation parameters for the fourteen non-shaded tests indicated in Table 4-1 including the $\lambda$ factor given in Eq. 4-1. The values of $E_{m}$ shown in Table 4-2 are prism test values taken from References 63 and 64 . Since the tests indicate that the panel failure mode is crushing of the upper corner HCT units, it is judged that the these corner areas are in a state of biaxial compression due to the resultant diagonal thrust. As noted in Section 2, the prism tests indicate that the compression strength is different for loading parallel to the HCT cells and normal to the HCT cells. In Table 4-2, the effective ultimate compression stress, $\mathrm{f}^{\prime}{ }_{\text {meff }}$, has been taken as the geometric mean of the normal and parallel prism tests. The tabulated $\mathrm{f}_{\mathrm{m} \text {-eff }}^{\prime}$ values in Table 4-2 are determined from the UT prism test results as shown in Table 3-1 for the UT panel tests (Test Nos. 1 through 20) and from the average of all NIST prism tests as shown in Table 3-1 for the ISU panel tests (W1 \& W2). Review of Refs. 46 and 16 indicate that the test walls were constructed with a wide range of mortar strengths. 
If the equivalent strut idealization can be used to represent capacity, then the test loads should be approximately inversely proportional to $\lambda$ and directly proportional to $f^{\prime}{ }_{m-\text { eff }} \times t$. Table $4-3$ provides a regression of $\lambda$ versus test capacity/( $\left(\mathrm{x} \mathrm{f}^{\prime}{ }_{\text {m-eff }}\right)$.

$$
\mathrm{P}=\mathrm{f}_{\mathrm{m} \text {-eff }}^{\prime} \times \mathrm{t} \times 8.3
$$

As can be noted, the comparison of this estimator with the test capacities yields an average ratio of unity and a COV of approximately 0.11 . Equation 4-4 was derived for panel length to height ratios between 1. and 1.5. This equation may be unconservative for length/height significantly below 1.0 and excessively conservative for length to height greater than 1.5.

\subsection{EQUIVALENT STRUT MODEL OF WALL STIFFNESS}

While the characteristic parameter, $\lambda$ did not seem to correlate with the test capacity data as well as the simple expression of Eq. 4-4, we feel that the strut model does provide a reasonable basis for modeling the infill stiffness. The strut model (Eqs. 4-1, 4-2, \& 4-3) may be modified to reflect the wall stiffness associated with a given level of displacement as indicated in Reference 46 (repeated in Ref. 1). By such an approach, the effective strut stiffness, or the product of modulus times area (EA) $)_{\text {eff }}$ of the equivalent strut is reduced by a parameter $(4 / \mathrm{C})$ as shown in Eq. $4-5$, where $\mathrm{C}$ is a function of horizontal wall displacement. It should be noted that this formulation is numerically equivalent to the approach presented in Refs 46 and 1:

$$
(\mathrm{EA})_{\mathrm{eff}}=\mathrm{E}_{\mathrm{m}}(4 / \mathrm{C}) \mathrm{wt}
$$

The value of $\mathrm{C}$ (minimum $=5$ for near elastic response levels and a maximum of 18 for response associated with the panel capacity) is a function of the secant stiffness of the load deflection curve, as given in Table 2-1. The effective length of column bearing contact, should be limited to no more than $0.2 \times$ wall height, h'.

\subsection{EVALUATION OF FRAME MEMBERS AND CONNECTIONS}

It is our opinion that all connections should be evaluated assuming full force transfer (i.e., without friction) of the forces induced by the resultant diagonal thrust (effective compression strut). While the testing (both the HCTW Program and other masonry infill tests) indicate that there is frictional force transfer between the infill and frame, these forces cannot be reliably quantified.

The vertical component of the diagonal strut is resisted by the confining beam of the frame. The beam to column connection should be considered to transfer this entire shear. Further, in a structure, the in-plane horizontal force is applied to the wall by diaphragm or floor slab drag forces along the beam. The beam/column connection should also be considered to transfer this resultant tension (or compression). At 
the base reaction end of the effective strut, column anchors should be considered to transfer both the horizontal thrust and any vertical uplift induced by the adjacent infill panel.

\subsection{EQUIVALENT DAMPING FROM WALL LOAD-DISPLACEMENT HYSTERESIS}

Examination of the hysteresis loops associated with peak loading (Appendix B) indicates that the effective viscous damping represented by the hysteretic energy dissipated per cycle, or the enclosed area of the loop, is approximately $5 \%$ for the macro-walls and $10 \%$ for the full-scale walls. If we view the simple structure (two independent infilled frames). subjected to the shake table testing (Ref. 45) as an approximate SDOF system, then the 5\% damped response spectrum (an assumption; the response spectra given in Ref. 45 are not labeled) for the $16 \mathrm{x}$ reference motion is approximately $10 \mathrm{~g}$. Ref. 45 indicates that the maximum wall loading for this input was approximately 48 kips and that the slab weight was 9.5 kips, thus $48 /(9.5 / 2)=10 \mathrm{~g}$, which indicates that the effective hysteretic damping was approximateiy $5 \%$ during the test.

It should be noted that the above estimates of damping represent the hysteretic energy of an effective element consisting of a single infilled frame bay. NUREG CR-3805 indicates that, for hysteresis loops which have strongly pinched behavior (such as the HCTW load deflection curves, the energy dissipation can be accounted for in a secant model by adding the effective hysteretic damping to the elastic material damping. Elastic material damping for hollow clay tile masonry construction is judged to be on the order of 4 to 7 percent. These are the Response Level 1 and 2 (i.e., elastic behavior) damping values for masonry construction from DOE-STD-1020-94. Hence, the total damping (hysteretic plus elastic material) to be used for response analyses is expected to be between about 10 and $15 \%$.

\subsection{EFFECT OF OUT-OF-PLANE LOADS ON IN-PLANE WALL CAPACITY}

The effect of prior $1 \%$ out-of-plane drift response of the wall did not appear to have a significant effect on in-plane capacity. Likewise, the effect of prior out-of-plane loading did not appreciably affect the in-plane capacity. However, the effect of concurrent lateral loading and in-plane loading did have an affect on in-plane test capacity. The failure mode of the wall was a compression failure at the bottom course of the wall due to the combined vertical compression component of the strut thrust and the compression induced by vertical arching due to the lateral out-of-plane load. Based on these observations, it is concluded that the interaction between in-plane and out-of-plane loads should be considered. 


\subsection{EFFECT OF WALL ECCENTRICITY}

The testing seems to support the contention that only the wall thickness confined within the steel frame is effective for capacity determination or for idealization of an effective compressive strut.

\subsection{EFFECT OF PILASTERS}

Refs. 46 and 16 suggest differing approximations to account for the stiffening effect of the pilaster on column flexure. The value of EI given in Table 4-2 for the two ISU walls includes the mortar confined between the column flanges. However, since the value of $\lambda$ is not overly sensitive to the value of EI, we recommend that only the steel column EI be considered as the effective EI of the pilaster in Eq. 4-1.

\subsection{EFFECT OF COLUMN-WALL AND BEAM-WALL GAPS}

A test with a 1 in. gap between the wall and the column indicated that the cyclic behavior of the wall is similar to a wall without a gap except for the effect of a reduced secant stiffness caused by the additional displacement associated with the gap. The effect appears to be an approximate 10-15\% reduction in capacity.

The HCTW program did not consider the effect of beam/wall gaps. Dawe and Seah (Ref. 52) indicate that there is a $50 \%$ reduction in capacity for concrete masonry infills tested with a $20 \mathrm{~mm}$ gap.

\subsection{EFFECT OF WALL OPENINGS}

The basis of the wall opening criteria given in Reference 1 is not based on the test results of the HCTW program but rather review of Refs. 69 and 70. The only opening considered in the HCTW program was a opening in the corner of the infilled panel. This had a dramatic effect on the behavior of the infill with an approximate $60 \%$ reduction in capacity.

\subsection{EFFECTS OF FRAME BEAM-COLUMN AND COLUMN BASE CONNECTION DETAILS}

All tests specimens (macro, full) utilized slip-critical A325 bolted connections that were overstrength to prevent connection behavior issues. This is reasonable since the focus of the test programs was the strength behavior of the masonry infill and not the strength of the frame. However, the actual Y12 frame are vintage (1950s) riveted connections which are considered as bearing connection and subject 
to slip. The authors of both Ref. 46 and 16 have indicated that although the connections were designed as slip critical, considerable connection slip did actual occur as the test specimens were cycled at load levels approaching capacity leveis. Thus, we conclude that the test capacity levels include the effects of connection slip. 
Table 4.1. In-Plane Net Horizontal Panel Test Capacities and Displacements

\begin{tabular}{|c|c|c|c|c|c|c|c|}
\hline $\begin{array}{l}\text { Test } \\
\text { No. }\end{array}$ & $\begin{array}{l}\text { Test } \\
\text { Load } \\
\end{array}$ & $\begin{array}{l}\text { Panel } \\
\text { Capacity } \\
\text { P-net }(-)\end{array}$ & $\begin{array}{l}\text { Displacement } \\
\mathrm{d}(-) \\
\end{array}$ & $\begin{array}{c}\text { Panel } \\
\text { Capacity } \\
\text { P-net }(+)\end{array}$ & $\begin{array}{l}\text { Displacement } \\
\mathrm{d}(+)\end{array}$ & $\begin{array}{c}\text { Panel } \\
\text { Capacity } \\
\text { P-net (avg) }\end{array}$ & $\begin{array}{l}\text { Displacement } \\
\text { d (avg) }\end{array}$ \\
\hline 1 & \multirow{14}{*}{$\begin{array}{c}\text { In-Plane } \\
\text { Only }\end{array}$} & 27.0 & 1.08 & 36.9 & 0.77 & 32.0 & 0.93 \\
\hline 2 & & 35.2 & 1.10 & 38.9 & 1.08 & 37.1 & 1.09 \\
\hline 3 & & 31.3 & 0.67 & 34.5 & 0.57 & 32.9 & 0.62 \\
\hline 4 & & 48.3 & 0.86 & 31.6 & 0.68 & 40.0 & 0.77 \\
\hline 5 & & 39.5 & 0.62 & 33.4 & 0.57 & 36.5 & 0.60 \\
\hline 7 & & 29.6 & 0.84 & 27.4 & 0.73 & 28.5 & 0.79 \\
\hline 9 & & 40.4 & 0.45 & 38.0 & 0.53 & 39.2 & 0.49 \\
\hline $10 \mathrm{a}$ & & 38.6 . & $0 \% 7$ & 26.3. & $1844 \%$ & 32.5 . & 0919. \\
\hline $10 \mathrm{~b}$ & & 80.3. & 110 & 310 & 090 & 80\%? & $100 \%$ \\
\hline 17 & & 44.9 & 1.22 & 39.9 & 1.62 & 42.4 & 1.42 \\
\hline $21 \mathrm{a}$ & & 35.0 & 1.48 & 41.6 & 1.31 & 38.3 & 1.40 \\
\hline $21 b$ & & 33. & 1.44. & 25.8. & 1.24. & 29.6 & $13.4 \%$ \\
\hline 24 & & 130 & $0.6 \%$ & $27 \%$ & $0 \% 64$ & 27718 & 0.70 \\
\hline W2 & & 60.1 & 0.76 & 50.3 & 1.00 & 55.2 & 0.88 \\
\hline 11 & Out-of-Plane & 32.9 & 0.42 & 32.3 & 0.62 & 32.6 & 0.52 \\
\hline 13 & drift then & 40.2 & 0.75 & 35.9 & 0.66 & 38.1 & 0.71 \\
\hline W1 & In-plane & 58.6 & 0.82 & 40.8 & 1.00 & 49.7 & 0.91 \\
\hline 20 & Out-of-Plane & 39.6 & 0.71 & 29.5 & 0.73 & 34.6 & 0.72 \\
\hline 23 & $\begin{array}{c}\text { pressure } \\
\text { then } \\
\text { In-plane } \\
\end{array}$ & $21.9 \%$ & 0.36 . & $18.2 \%$ & 0.56. & 20.1 & 0.56 \\
\hline
\end{tabular}

Notes:

- Panel capacity is the net panel capacity equal to the test load minus the frame load.

- Capacities and displacements are in the horizontal direction.

- Capacities are kips, displacements are in inches.

- Test 10a has 1 inch column gap such test displacements are reduced by one inch.

- For Tests 24, 11, 13, 20, and 23, the frame stiffness of Test 2 was used.

- For Tests W1 and W2, frame stiffness of $7 \mathrm{kips} /$ inch was used.

- Shaded tests have special boundary conditions or loading combinations. 
Table 4.2. Test Specimen Evaluation Parameters

\begin{tabular}{|c|c|c|c|c|c|c|c|c|c|}
\hline $\begin{array}{c}\text { Test } \\
\text { No. }\end{array}$ & $\begin{array}{c}\text { Panel } \\
\text { width } \\
\text { (inches) }\end{array}$ & $\begin{array}{c}\text { Panel } \\
\text { height } \\
\text { (inches) }\end{array}$ & $\begin{array}{c}\theta \\
\text { (degrees) }\end{array}$ & $\mathbf{C o l u m n}$ & $\begin{array}{c}\mathbf{I}_{\text {col }} \\
\left(\mathbf{i n}^{4}\right)\end{array}$ & $\begin{array}{c}\text { Wall } \\
\text { effective } \\
\text { thickness, }\end{array}$ & $\begin{array}{c}\mathbf{E}_{\mathbf{m}} \\
\text { (psi) }\end{array}$ & $\begin{array}{c}\mathbf{f}_{\text {m-ert }} \\
\text { (psi) }\end{array}$ & $\lambda$ \\
\hline 1 & 88 & 88 & 45.0 & $\mathrm{~W} 10 \times 12$ & 2.2 & 7.67 & 329000 & 594 & 0.1032 \\
\hline 2 & 88 & 88 & 45.0 & $\mathrm{~W} 10 \times 30$ & 16.7 & 7.67 & 329000 & 594 & 0.0620 \\
\hline 3 & 88 & 88 & 45.0 & $\mathrm{~W} 10 \times 45$ & 53.4 & 7.67 & 329000 & 594 & 0.0464 \\
\hline 4 & 88 & 88 & 45.0 & $\mathrm{~W} 16 \times 26$ & 9.6 & 13 & 410000 & 351 & 0.0859 \\
\hline 5 & 88 & 88 & 45.0 & $\mathrm{~W} 16 \times 40$ & 28.9 & 13 & 410000 & 351 & 0.0652 \\
\hline 7 & 88 & 88 & 45.0 & $\mathrm{~W} 10 \times 30$ & 16.7 & 4.67 & 329000 & 594 & 0.0548 \\
\hline 9 & 88 & 88 & 45.0 & $\mathrm{~W} 10 \times 30$ & 170.0 & 7.67 & 329000 & 594 & 0.0347 \\
\hline 17 & 136 & 88 & 32.9 & $\mathrm{~W} 10 \times 30$ & 16.7 & 7.67 & 329000 & 594 & 0.0606 \\
\hline $21 \mathrm{a}$ & 112 & 88 & 38.2 & $\mathrm{~W} 10 \times 30$ & 16.7 & 7.67 & 329000 & 594 & 0.0616 \\
\hline $\mathrm{W} 2$ & 288 & 245 & 40.4 & $\mathrm{~W} 10 \times 33$ & 66.0 & 10 & 660000 & 587 & 0.0432 \\
\hline 11 & 88 & 88 & 45.0 & $\mathrm{~W} 10 \times 30$ & 16.7 & 7.67 & 329000 & 594 & 0.0620 \\
\hline 13 & 88 & 88 & 45.0 & $\mathrm{~W} 10 \times 30$ & 16.7 & 7.67 & 329000 & 594 & 0.0620 \\
\hline $\mathrm{W} 1$ & 288 & 245 & 40.4 & $\mathrm{~W} 10 \times 33$ & 66.0 & 10 & 660000 & 587 & 0.0432 \\
\hline 20 & 88 & 88 & 45.0 & $\mathrm{~W} 10 \times 30$ & 16.7 & 7.67 & 329000 & 594 & 0.0620 \\
\hline
\end{tabular}


Table 4.3. Regression of $\lambda$ vs. Test Capacity $/\left(\mathbf{t} \times \mathbf{f}^{\prime}{ }_{\mathrm{m} \text {-eff }}\right)$

\begin{tabular}{|c|c|c|}
\hline Test No. & $\ln (\lambda)$ & $\ln \left(\right.$ Test Capacity $/\left(\mathrm{t} \times \mathrm{f}_{\mathrm{m} \text {-eff }}^{\prime}\right)$ \\
\hline 1 & -2.271158199 & 1.947731525 \\
\hline 2 & -2.780179159 & 2.095827696 \\
\hline 3 & -3.070779666 & 1.977032002 \\
\hline 4 & -2.454574164 & 2.16964837 \\
\hline 5 & -2.730354341 & 2.077961157 \\
\hline 7 & -2.904218545 & 2.329620975 \\
\hline 9 & -3.360276589 & 2.152236091 \\
\hline 17 & -2.8031545 & 2.230707706 \\
\hline $21 \mathrm{a}$ & -2.787379657 & 2.12900924 \\
\hline W2 & -3.142499019 & 2.241108319 \\
\hline 11 & -2.780179159 & 1.967871633 \\
\hline 13 & -2.780179159 & 2.122460429 \\
\hline W1 & -3.142499019 & 2.136150299 \\
\hline \multirow[t]{4}{*}{20} & -2.780179159 & 2.025966894 \\
\hline & slope, $\mathrm{m}$ & -0.132050162 \\
\hline & intercept, b & 1.739240852 \\
\hline & $e^{b}$ & 5.693019938 \\
\hline
\end{tabular}

Estimated capacity may be determined from the slope and intercept from linear regression analysis of the above data as follows:

$$
\mathrm{P}_{\text {est. capacity }}=\mathrm{f}_{\text {m-eff }}^{\prime} \times \mathrm{t} \times\left(5.693 \times \lambda^{-0.132}\right)
$$

where $5.693 \times \lambda^{-0.132}=7.7$ for $\lambda=0.1032$ (maximum value from Table 4-2)

and $\quad 5.693 \times \lambda^{-0.132}=8.9$ for $\lambda=0.0347$ (minimum value from Table 4-2) 
Table 4.4. Comparison of Predicted Horizontal In-plane Capacitieswith Test Results

\begin{tabular}{|c|c|c|c|c|c|}
\hline $\begin{array}{l}\text { Test } \\
\text { No. }\end{array}$ & $\begin{array}{r}\mathbf{f}_{\text {meff }}^{\prime} \\
\text { (psi) }\end{array}$ & $\begin{array}{c}\text { Effective wall } \\
\text { thickness, } t \\
\text { (inches) }\end{array}$ & $\begin{array}{c}\text { Predicted } \\
\text { Panel } \\
\text { Capacity } \\
\text { (kips) }\end{array}$ & $\begin{array}{l}\text { Test Panel } \\
\text { Capacity } \\
\text { (kips) }\end{array}$ & $\begin{array}{c}\text { Ratio of Test } \\
\text { to Predicted } \\
\text { Capacity }\end{array}$ \\
\hline 1 & 594.0 & 7.67 & 37.81 & 32.0 & 0.84 \\
\hline 2 & 594.0 & 7.67 & 37.81 & 37.1 & 0.98 \\
\hline 3 & 594.0 & 7.67 & 37.81 & 32.9 & 0.87 \\
\hline 4 & 351.0 & 13.00 & 37.87 & 40.0 & 1.05 \\
\hline 5 & 351.0 & 13.00 & 37.87 & 36.5 & 0.96 \\
\hline 7 & 594.0 & 4.67 & 23.02 & 28.5 & 1.24 \\
\hline 9 & 594.0 & 7.67 & 37.81 & 39.2 & 1.04 \\
\hline 17 & 594.0 & 7.67 & 37.81 & 42.4 & 1.12 \\
\hline $21 \mathrm{a}$ & 594.0 & 7.67 & 37.81 & 38.3 & 1.01 \\
\hline W2 & 587.0 & 10.00 & 48.72 & 55.2 & 1.13 \\
\hline 11 & 594.0 & 7.67 & 37.81 & 32.6 & 0.86 \\
\hline 13 & 594.0 & 7.67 & 37.81 & 38.1 & 1.01 \\
\hline W1 & 587.0 & 10.00 & 48.72 & 49.7 & 1.02 \\
\hline 20 & 594.0 & 7.67 & 37.81 & 34.6 & 0.91 \\
\hline & & & \multicolumn{2}{|c|}{ Average } & 1.00 \\
\hline & & & \multicolumn{2}{|c|}{ Standard deviation } & 0.11 \\
\hline & & & \multicolumn{2}{|c|}{ Coefficient of variation } & 0.11 \\
\hline
\end{tabular}

Predicted panel capacity $=\mathrm{f}_{\text {m-eff }}^{\prime} \times \mathrm{t} \times 8.3 / 1000$ 


\section{OUT-OF-PLANE WALL BEHAVIOR}

\subsection{GENERAL BEHAVIOR}

The behavior of walls to imposed out-of-plane drift and the behavior of walls with out-of-plane lateral loading was considered in the test programs reported in Refs. 16,45, 46, and 50. Ref. 16 (full scale wall test) consider out-of-plane drift loading only. Ref. 50 reports the results of an in-situ test on an actual Y-12 Building wall. Ref. 46 reports on three lateral loading tests performed on macro-walls plus one test on a wall with prior in-plane loading. An additional test considered concurrent in-plane and out-of-plane loading. Ref. 45 reports on the shake table testing of macro-walls with out-of-plane base input. However, Ref. 45 does not contain any correlation with expected wall behavior and does not appear to have subjected the walls to out-of-plane motion levels which would cause arching of the walls.

\subsection{RESPONSE TO STORY DRIFT}

The out-of-plane test behavior of walls subjected to drift imposed by either a diaphragm or a floor slab was considered in both Refs. 16 and 46 . Both test programs tested the walls with a cyclic imposed drift ratio of $1 \%$ and concluded that wall capacity was not affected by drifts of this order.

\subsection{RESPONSE TO LATERAL OUT-OF-PLANE INERTIA LOADS}

Refs. 46 and 50 provide the primary data for the behavior of HCT walls subjected to lateral out-ofplane inertia loading as simulated by static air bag loading. Ref. 46 subjected the test walls to cyclic pressure application at each increment of loading while Ref. 50 subjected the test wall to increasing static pressure only. It should be noted that the vertical wall edge conditions were such that horizontal arching was minimal. All of the walls failed by one-way vertical arching between the floor and confining beam.

Ref. 46 (and Ref. 51) used the formulation proposed by Dawe and Seah (Ref. 53) to express wall capacity under arching conditions. The formulation proposed by Dawe and Seah is based on a parametric analytical study without direct comparison to test data. We have checked the formulation for a few of the Dawe and Seah test results as well as the UT tests (Appendix C). The relationship seems to predict the maximum lateral wall test loads with reasonable accuracy.

\subsection{EVALUATION OF FRAME MEMBERS AND CONNECTIONS}

While the behavior of the confining frame was monitored in the out-of-plane tests reported in Refs. 46 and 50, no guidance has been provided concerning the additional loading imposed on confining members and connections due to the vertical arching behavior of wall under lateral out-of-plane loading. 


\subsection{EFFECT OF IN-PLANE LOADING ON OUT-OF-PLANE CAPACITY}

The effect of prior out-of-plane drift response results in cracking at the base course of the wall which did not seem to affect the in-plane capacity of the macro walls tested nor the full scale wall tested. The converse condition of the effect of drift on walls damaged by in-plane loading or out-of-plane lateral loading was not tested.

One out-of-plane pressure test was conducted for a wall with prior in-plane loading which resulted in an approximate $20 \%$ reduction in out-of-plane capacity. The concurrent combined effect of out-of-plane and in-plane loading has been discussed above in Section 4.6. 


\section{EVALUATION OF DEMAND FOR HCTW BUILDINGS}

\subsection{GENERAL CONSIDERATIONS}

- The in-plane stiffness of unreinforced masonry infill walls can be incorporated into seismic response analyses by means of equivalent two-dimensional diagonal strut elements. The equivalent strut element must be developed to exhibit wall stiffness while only acting in compression. Techniques for modeling infills using "equivalent struts" have been published as far back as the early 1960's $[54,60]$.

- Because the in-plane stiffness of HCTW infilled frame degrades with deformation, nonlinear behavior of the wall must be considered. Equivalent linear resistance function models may be developed to simulate this nonlinear behavior. For evaluation of Oak Ridge buildings, an equivalent linear approach using the "secant" stiffness is employed. Response spectrum analysis techniques can be used for HCTW buildings with the secant stiffness based on estimates of response displacements. Obtaining convergence between assumed displacement and response displacement is an iterative process.

- $\quad$ Out-of-plane demand on HCTW infill results from story drifts imposing wall deformation and from seismic inertial loads. Story drifts are determined directly from the overall seismic response analysis. In addition, accelerations at the top and bottom of walls may be determined from the overall seismic response analysis. These values may then be used to assess the out-of-plane wall response to inertia load by separate calculation. Amplification of out-of-plane seismic response must be estimated by considering the relation between the wall out-of-plane natural frequency and the frequency content of the response accelerations.

- Behavior of HCTW construction with openings is not well characterized by the test program. Rules for wall stiffness and strength may be developed from the literature on unreinforced masonry infill or may require more sophisticated analytical techniques.

- In general, HCTW buildings should be analyzed using three-dimensional building analyses to capture the effects of torsional response, particularly in irregularly shaped buildings. 
- Equivalent strut properties should be formulated without considering vertical loads. Consequently, evaluations of the frame should be performed without vertical loads, then superimposing the vertical loads on the frame members by load combination rules.

\subsection{EVALUATION OF HCTW SEISMIC DEMAND}

\subsubsection{Evaluation of Overall Seismic Response}

As discussed in Section 2, the testing to date has addressed steel frames with solid infills. Those tests have established force-deformation curves for panels with different physical characteristics, boundary conditions, and material properties.

A dynamic model of the building can be developed using a linear elastic finite element computer program. Alternately, it is permissible to perform nonlinear seismic analyses. A detailed three dimensional model may be used to establish stiffness properties for use with a simplified model for dynamic analysis. Alternately, the 3-D model may be used for the dynamic seismic response analysis.

All beams and columns into which infill panels are included should be represented as beam elements. For the construction at the Oak Ridge Y-12 plant, pinned connections should be assumed at the base of the columns and at all beam-column connections. All infilled HCT panels should be modeled as diagonal struts. The panels may be represented either as a single strut or as 2 struts in an "X-bracing" configuration with each strut at $1 / 2$ the total wall stiffness in the analytical model. It is our understanding that analyses of buildings at Oak Ridge are performed using a single diagonal strut which is capable of withstanding both tension and compression loads.

Linear elastic seismic analyses may be performed using the response spectrum modal superposition method. The input response spectrum for building analyses should be the median amplification site-specific ground motion for the site at the mean annual probabilities of exceedance for the building performance category in accordance with DOE 5480.28 and DOE-STD-1020-94. Spectra at 10 percent of critical damping may be used for evaluation of buildings where HCT infill walls are the lateral force resisting system. This system damping is a combination of energy dissipated in material damping and in hysteresis loops during cyclic wall response as discussed in Section 4.

Modal properties of HCTW buildings depend on the displacement response levels reached as the stiffness of such walls is a function of the wall deformation. Hence, estimates of building deformations are made to establish wall stiffness properties. The resulting deformations from the response analysis must be compared to the estimated deformations and an iteration may be needed such that calculated and assumed displacements are sufficiently close that the building modal properties are consistent with the response. 


\subsubsection{Strut Properties}

The equivalent strut properties can be modeled using the method introduced by Stafford Smith [60] and modified by Flanagan [2]. The method presented by Flanagan includes the introduction of a " $\mathrm{C}$ " factor utilized for evaluating the wall secant stiffness as a function of wall displacement. Strut stiffness should be determined in accordance with Equation $4-5$ combined with Equations 4-1, 4-2, and 4-3. The gross elastic modulus of the HCTW, $E_{\mathrm{m}}$, may be taken as 350 and $400 \mathrm{ksi}$, as estimated from 8 " and 13" prism tests, respectively. These moduli are representative of masonry stiffness as measured parallel to the unit cells.

The value of $\mathrm{C}$ is a function of the secant stiffness from the load deflection curves which were observed in the HCTW test program. A C value should assumed, then readjusted iteratively to develop the correct stiffness for the panel. As stated earlier, the goal is to assure that the building modal properties are reasonably consistent with the building seismic response. It is not necessary that the calculated and assumed deformations are exactly equal.

HCTW seismic acceptance criteria for in-plane behavior, as presented in the following section, consists of maximum wall forces and maximum wall displacements. If the maximum wall force is reached prior to maximum wall displacement, it is permissible to reduce the stiffness of the wall and allow seismic forces to redistribute to adjacent lateral force resisting elements. A new seismic response analysis is then performed with walls at reduced secant stiffness corresponding to limiting or expected maximum displacement. The $\mathrm{C}$ factor may be used to develop the revised secant stiffness as a function of wall displacement.

\subsubsection{Evaluation of Out-of-Plane Demand}

The overall seismic response analysis gives out-of-plane displacements and accelerations at model node points. The out-of-plane displacements may be used to compute story drifts which may be compared to story drift limits. The out-of-plane accelerations may be used to develop seismic inertial loads on the wall by separate calculations. The demand may be determined from floor spectra at the wall location at the wall natural frequency. Alternately, it may be more practical to assume an amplification of 2 above the peak spectral acceleration from the ground response spectrum to conservatively estimate out-of-plane wall demand without estimating the wall frequency. It is suggested that this latter approach be applied first to see if the demand exceeds the capacity as discussed in the next section. Note that when out-of-plane and in-plane demands are combined, it should be done in a probabilistic manner such as the $100-40-40$ rule per ASCE 4-86. 


\subsection{SEISMIC DEMAND OF HCTW INFILL WITH OPENINGS}

Reference 1 provides a recommended practice to incorporate openings in HCTW for doors, windows, and other penetrations. This practice is to reduce the stiffness and/or capacity of the panels based on the location and size of the openings within the panel cross-section. The basis for these recommendations is from a single test (UT\#24) and from literature on unreinforced masonry infill (Refs. 69 and 70), which is not HCTW construction. Based on the UT\#24 test results, one modification to Ref. 1 has been proposed. For walls with a comer opening, Ref. 74 recommends using a $50 \%$ reduction for strength and a $75 \%$ reduction for stiffness. The recommended reductions for developing in-plane stiffness and capacity appear to be consistent with these data. Recommended criteria for walls with openings is provided in Section 2.

\subsection{FRAME CONNECTIONS}

For Buildings 9212 and 9207 , the column base connection and standard beam (shear) connections are Type 2 flexible connections which can only develop approximately $10 \%$ of section moment capacity. These web (only) connections are commonly considered to be effective pin connections since the flanges are not directly in the connection load path. The top and seat angle connection, however, does provide a load path to the beam flanges. These type of connections are also referred to as Type 2 flexible connections with approximately $50 \%$ section moment capacity. The consideration of the approximate stiffness for the connection is required for including this type of connection in an analysis. Often, the simpler approach of considering this connection as an effective pin is employed. 


\section{CAPACITY OF HCTW BUILDING ELEMENTS}

\subsection{DOE SEISMIC CRITERIA BASED ON TARGET PERFORMANCE GOALS}

Acceptance criteria for unreinforced infilled HCTW at Oak Ridge are presented in this section. These criteria are based on the target performance goals of DOE 5480.28. This section also presents the background and methodology used to establish these criteria.

DOE 5480.28 requires that structures, systems, and components (SSCs) are able to withstand the effects of natural phenomena hazards. For SSCs to comply with the Order, it must be demonstrated that there is a sufficiently low probability of damage/failure of those SSCs consistent with specified target performance goals. These goals are specified in terms of an permissible annual probability of unacceptable performance. Different performance goals are assigned to categories (Performance Categories 0 through 4) of SSCs depending on their required performance as shown below.

\begin{tabular}{|c|l|c|}
\hline $\begin{array}{c}\text { Performance } \\
\text { Category }\end{array}$ & $\begin{array}{c}\text { Description of Performance } \\
\text { Required }\end{array}$ & $\begin{array}{c}\text { Target Seismic } \\
\text { Performance Goal }\end{array}$ \\
\hline PC 0 & No Consideration & N/A \\
\hline PC 1 & Prevent Structural Collapse & $1 \times 10^{-3}$ \\
\hline PC 2 & Maintain Essential Functions & $5 \times 10^{-4}$ \\
\hline PC 3 & $\begin{array}{l}\text { Confinement of Hazardous } \\
\text { Materials }\end{array}$ & $1 \times 10^{-4}$ \\
\hline PC 4 & $\begin{array}{l}\text { Confinement of Hazardous } \\
\text { Materials }\end{array}$ & $1 \times 10^{-5}$ \\
\hline
\end{tabular}

DOE-STD-1020-94 provides design/evaluation criteria based on the target performance goals for new and existing SSCs. However, the deterministic seismic evaluation and acceptance criteria in the standard do not apply to HCTW construction. As a result, new criteria must be developed for use in evaluating the HCTW buildings at Oak Ridge.

The basic intent of the deterministic seismic evaluation and acceptance criteria specified in DOESTD-1020-94 is to achieve less than a $10 \%$ probability of unacceptable performance for an SSC subjected to a scaled design/evaluation basis earthquake (SDBE) defined by:

$$
\mathrm{SDBE}=(1.5 \mathrm{SF}) *(\mathrm{DBE})
$$

where SF is a seismic scale factor depending on the Performance Category of the SSC and DBE is the design/evaluation basis earthquake defined in accordance with the provisions of DOE-STD-1020-94.

SF is unity for Performance Category 3 , which is the category for most Oak Ridge buildings. In other words, by DOE-STD-1020-94 criteria, the 10\% failure capacity must exceed the DBE by a factor of $1.5 \mathrm{SF}$. 
In terms of median capacity and demand, the required factor of safety, $\mathrm{F}_{\text {Srged }}$ is given by (UCRL/CR111478, "Basis for Seismic Provisions of DOE-STD-1020"):

$$
\mathrm{F}_{\mathrm{Srqd}}=1.5 * \mathrm{SF} * \mathrm{e}^{1.282 \beta} \mathrm{FS}
$$

The required factor of safety is the ratio between the median specified capacity and the median specified demand. $\beta_{\mathrm{FS}}$ is the total uncertainty in the factor of safety.

The factor of safety discussed above may be utilized to develop criteria for seismic loading which is based on the target performance goals from DOE 5480.28. In addition, DOE-STD-1020-94 provides criteria for permissible displacements. By these criteria, displacements are to be limited to levels at which there is a $5 \%$ probability of unacceptable performance. Equation 7-2 and the displacement criteria will be used to develop seismic criteria for HCTW construction as discussed in the remainder of this section.

\subsection{IN-PLANE HCTW PANEL CAPACITY}

The median factor of safety, $F_{\mathrm{S} 50}$, is given by the ratio of the median capacity to the median demand as follows:

$$
\mathrm{F}_{\mathrm{SS0}}=\mathrm{C}_{50} * \mathrm{~F}_{\mu 50} / \mathrm{D}_{\mathrm{s} 50}
$$

where $C_{50}, D_{550}$, and $F_{500}$ are median estimates of the capacity, seismic demand and inelastic energy absorption factor. From the HCTW test data, hysteresis loops exhibit strongly pinched behavior such that it is judged that the limited inelastic energy absorption capacity may be accounted for through the use of increased viscous damping as discussed in Section 3 and with an inelastic energy absorption factor of unity. Hence:

$$
\mathrm{F}_{\mathrm{S50}}=\mathrm{C}_{50} / \mathrm{D}_{\mathrm{S50}}
$$

The median capacity and demand are given by:

$$
\begin{aligned}
& \mathrm{C}_{50}=\mathrm{F}_{\mathrm{C}} * \mathrm{C}_{\mathrm{C}} \\
& \mathrm{D}_{\mathrm{S} 50}=\mathrm{D}_{\mathrm{S}} / \mathrm{F}_{\mathrm{R}}
\end{aligned}
$$

where $C_{C}$ is the wall panel capacity evaluated in accordance with the provisions in this section and $D_{S}$ is the seismic demand evaluated in accordance with Section $6 . F_{C}$ and $F_{R}$ are the median factors of safety or conservatism associated with the evaluation of $C_{C}$ and $D_{S}$.

For HCTW walls, in-plane capacity will be determined from the test data using the prediction equation discussed in Section 4. This equation provides an estimate of the median wall capacity, $P_{E Q}=C_{50}$. Conservatism will be introduced through the use of conservative material properties and a strength reduction factor, $\Phi$. Note that the prediction equation has been developed in a manner that $F_{E Q}$ is unity as described in Section 4. Conservatism is needed to account for the uncertainty in hollow clay tile wall material properties and in the prediction of capacity by the equation. Note that $\beta_{\mathrm{EQ}}$ was calculated 
to be 0.11 in Section 4. In addition, there are other sources of uncertainty as discussed later in this section. Hence the factor of safety on capacity, $F_{C}$ is made up of a factor of safety on material strength, $F_{M}$ and the strength reduction factor, $\Phi$, such that:

$$
\begin{aligned}
& \mathrm{F}_{\mathrm{C}}=\mathrm{F}_{\mathrm{M}} / \Phi \\
& \mathrm{C}_{\mathrm{C}}=\Phi \mathrm{P}_{\mathrm{EQ}} / \mathrm{F}_{\mathrm{M}}
\end{aligned}
$$

where $\mathrm{C}_{\mathrm{C}}$ is the horizontal wall panel capacity limit.

By the provisions of the Uniform Building Code (UBC), masonry strength for design and evaluation purposes is taken as 3/4 of the median masonry strength. By DOE-STD-1020-94 provisions, material strengths are to be taken at the $95 \%$ exceedance probability level. The masonry test data discussed earlier in this report indicates that uncertainty in the material strength of hollow clay tile prisms corresponds to $\beta_{\mathrm{M}}$ which is bounded by 0.2 , which corresponds to use of material strength equal to 0.72 of the median strength by the $95 \%$ exceedance probability provision. For HCTW construction, material strengths will be taken as $3 / 4$ of the median strength levels to be consistent to the UBC and to conform closely to DOE-STD-1020-94. Therefore, $F_{M}$ is $4 / 3$ and $\beta_{M}$ for independent prism strength (i.e., either normal or parallel) is 0.2 .

The strength reduction factor is evaluated below based on the target performance goals using Equations 7-2 through 7-6. Combining Equations 7-2, 7-4, 7-5, and 7-6 gives:

$$
\mathrm{F}_{\mathrm{M}} * \mathrm{~F}_{\mathrm{R}} / \Phi *\left(\mathrm{C}_{\mathrm{C}} / \mathrm{D}_{\mathrm{S}}\right)=1.5 * \mathrm{SF}^{*} \mathrm{e}^{1.282 \beta_{\mathrm{FS}}}
$$

At the point where the target performance goals are just met the capacity will equal the demand such that $C_{C} / D_{S}$ will equal unity and Equation 7-7 becomes:

$$
\mathrm{F}_{\mathrm{M}} * \mathrm{~F}_{\mathrm{R}} / \Phi=1.5 * \mathrm{SF}^{*} \mathrm{e}^{1.282}
$$

When $F_{M}, F_{R}$, and $\beta_{F s}$ are known, strength reduction factor, $\Phi$ may be computed by rearranging Equation 7-8 as follows:

$$
\Phi=\left(\mathrm{F}_{\mathrm{M}} * \mathrm{~F}_{\mathrm{R}}\right) /\left(1.5 * \mathrm{SF}^{*} \mathrm{e}^{1.282 \beta}{ }_{\mathrm{FS}}\right)
$$

$\beta_{\mathrm{FS}}$ may be computed from the following equation as a function of the uncertainty in capacity ${ }_{\mathrm{C}} \beta$ and uncertainty in response, $\beta_{R}$.

$$
\beta_{\mathrm{FS}}=\left(\beta_{\mathrm{C}}^{2}+\beta_{\mathrm{R}}^{2}\right)^{1 / 2}
$$

In order to evaluate $F_{R}$ and $\beta_{R}$, consider that by DOE-STD-1020-94, elastic computed seismic demand, $D_{S}$ is to be obtained in accordance with the requirements of ASCE 4-86 except that median input spectral amplifications are to be used instead of median plus one standard deviation amplification factors. UCRL/CR-111478, "Basis for Seismic Provisions of DOE-STD-1020" estimates that evaluation of seismic demand in this manner results in conservatism and uncertainty corresponding to $F_{R}$ of about 1.2 and $\beta_{R}$ of about 0.3 . The prediction equation for horizontal wall panel capacity developed in Section 3 is:

$$
\mathrm{P}_{\mathrm{EQ}}=8.3 * \mathrm{t}_{\mathrm{eff}} * \mathrm{f}_{\mathrm{m} \text {-eff }}^{\prime}
$$


where $\mathrm{f}_{\text {m-eff }}^{\prime}$ is the geometric average of the median masonry strength normal and parallel to the cells in the masonry units and $t_{\mathrm{eff}}$ is the thickness of the wall which does not protrude out from the frame members. This equation resulted in agreement with the test results such that to $F_{\mathrm{EQ}}$ was 1.0 and $\beta_{\mathrm{EQ}}$ was about 0.11 . However, capacity uncertainty, $\beta_{C}$ is a combination of equation uncertainty and material uncertainty. The uncertainty in material prism strengths, estimated to be on the order of $\beta_{\mathrm{M}}$ equal to about 0.2 , is part of the uncertainty in the prediction equation. Since $f^{\prime}{ }_{\text {m-eff }}$ is proportional to the geometric average of prism strengths, the composite uncertainty for material strength as used in the prediction equation may be determined from:

$$
\beta_{\mathrm{M}}=\left(\beta_{\mathrm{M} \text {-nornal }}^{2} / 2+\beta_{\mathrm{M} \text {-parallel }}^{2} / 2\right)^{1 / 2}
$$

Therefore, the composite uncertainty for material strength and prediction equation, $\beta_{\mathrm{m}}$ is expected to be about 0.14 (i.e., $0.2 / \sqrt{ } 2$ ). $\beta_{C}$ can be equal to or greater than the $\beta_{M}$ value of 0.14 . It is judged that $\beta_{\mathrm{c}}$ can be as large as about 0.25 . Therefore, values of $\Phi$ and $\beta_{\mathrm{FS}}$ are evaluated below using composite $\beta_{\mathrm{C}}$ of 0.14 , 0.2 , and 0.25 .

\begin{tabular}{|c|c|c|c|c|c|c|}
\hline $\mathbf{F}_{\mathrm{M}}$ & $\mathbf{F}_{\mathrm{RO}}$ & $\mathbf{F}_{\mathrm{R}}$ & $\beta_{\mathrm{C}}$ & $\boldsymbol{\beta}_{\mathrm{R}}$ & $\boldsymbol{\beta}_{\mathrm{RS}}$ & $\boldsymbol{\Phi}$ \\
\hline $4 / 3$ & 1.0 & 1.2 & 0.14 & 0.3 & 0.33 & 0.70 \\
\hline $4 / 3$ & 1.0 & 1.2 & 0.2 & 0.3 & 0.36 & 0.67 \\
\hline $4 / 3$ & 1.0 & 1.2 & 0.25 & 0.3 & 0.39 & 0.65 \\
\hline
\end{tabular}

The values given above are computed for SF equal to unity which is applicable to Performance Category 3. For other performance categories, the corresponding value of SF should be used from DOE-STD-102094 or the "Basis" document along with the specified value of $F_{M}$ and $\Phi$. Based on the above considerations, a value of $\Phi$ equal to $2 / 3$ is recommended for design and evaluation of HCTW infill walls at Oak Ridge. As a result, horizontal wall panel capacity is given by:

$$
\mathrm{C}_{\mathrm{C}}=8.3 \Phi * \mathrm{t}_{\text {eff }} * \mathrm{f}_{\mathrm{m} \text {-eff }}^{\prime} / \mathrm{F}_{\mathrm{M}}=4.15 * \mathrm{t}_{\mathrm{eff}} * \mathrm{f}_{\mathrm{m} \text {-eff }}^{\prime}
$$

The value given above is the capacity of the HCTW panel only. For those cases where the frame has moment connections, the capacity of the frame may be computed from its stiffness times the response displacement and added to the above capacity to produce the total capacity of the infill HCTW element.

Using the NIST-Group 2 and UT test data for masonry prism strength from References 63 and 64 and as summarized in Table 3-1 gives 647 psi for 8 inch walls and 420 psi for 13 inch walls as the effective prism strength, $\mathrm{f}_{\text {m-eff. }}$ Reference 63 points out that "the workmanship associated with the NIST Group 2 prisms was probably more typical of field construction practices than that associated with Groups 1 and 3." Furthermore, NIST-Group $1 \& 3$ strengths are much larger than other results for parallel loading. For these reasons, it is judged that the NIST-Group 2 and UT test data for masonry prism strength is most representative of $\mathrm{Y}-12$ construction. 
Reference 1 provides a recommended practice to incorporate openings in HCTW for doors, windows, and other penetrations. This practice is to reduce the stiffness and/or capacity of the panels based on the location and size of the openings within the panel cross-section. The basis for these recommendations is from a single test (UT\#24) and from literature on unreinforced masonry infill (Refs. 69 and 70), which is not HCTW construction. The recommended reductions for evaluation of in-plane capacity appear to be consistent with these data. Recommended reductions are presented in Section 2.

\subsection{EVALUATION OF FRAME CONNECTION CAPACITY}

Resistance of seismic-induced lateral forces by frames with hollow clay tile infill wall can produce significant forces on the frame connections. The beam-column connection experiences horizontal and vertical forces depending on the amount of friction between the wall and the column. The column base connection experiences tension and shear forces depending on the amount of friction between the wall and the underlying structure. Examination of test results indicates that it is prudent to ignore any transfer of load by friction such that frame connections take the full level of force in the strut representing the wall. Evaluation of frame connections should be performed in accordance with DOE-STD-1020-94 for the appropriate materials of construction taking $\mathrm{F}_{\mu}$ to be unity.

\subsection{IN-PLANE HCTW LIMIT DISPLACEMENTS}

The displacements associated with peak loading from each of the HCTW in-plane tests were presented in Section 4. These displacement values are repeated below:

\begin{tabular}{|l|l|l|l|l|l|l|l|l|l|l|l|l|l|l|}
\hline Test No. & 1 & 2 & 3 & 4 & 5 & 7 & 9 & 17 & $21 \mathrm{a}$ & W2 & 11 & 13 & W1 & 20 \\
\hline $\begin{array}{l}\text { Disp. } \\
\text { (in.) }\end{array}$ & 0.9 & $\begin{array}{l}1.0 \\
9\end{array}$ & $\begin{array}{l}0.6 \\
2\end{array}$ & $\begin{array}{l}0.7 \\
7\end{array}$ & $\begin{array}{l}0.6 \\
0\end{array}$ & $\begin{array}{l}0.7 \\
9\end{array}$ & $\begin{array}{l}0.4 \\
9\end{array}$ & $\begin{array}{l}1.4 \\
2\end{array}$ & $\begin{array}{l}1.4 \\
0\end{array}$ & $\begin{array}{l}0.8 \\
8\end{array}$ & $\begin{array}{l}0.5 \\
2\end{array}$ & $\begin{array}{l}0.7 \\
1\end{array}$ & $\begin{array}{l}0.9 \\
1\end{array}$ & $\begin{array}{l}0.7 \\
2\end{array}$ \\
\hline
\end{tabular}

As discussed in Section 4, the numbered tests are those conducted on 7.3 foot high walls at the University of Tennessee and the W1 and W2 tests are those conducted on 20 foot high walls at Iowa State University. Limit displacements for all tests are generally in the same range with little correlation to any test parameter. This is reasonable since, at peak loading, wall behavior is governed by crushing of the masonry unit at one corner of the wall independent of other wall parameters. As a result, for the purpose of developing HCTW acceptance criteria, limit in-plane wall displacement will be specified independent of wall geometry, stiffness, or strength parameters.

Displacement criteria from DOE-STD-1020-94 is to limit displacements to levels at which there is a $5 \%$ probability of unacceptable performance. The $5 \%$ failure probability displacement may be 
developed from the test data presented above. The median and lognormal standard deviation of the test displacement values is 0.80 inches and $\beta=0.31$. The $5 \%$ failure probability displacement may then be determined from:

$$
\Delta_{5 \%}=0.80 * \mathrm{e}^{-1.645(0.31)} \approx 0.5 \text { inches }
$$

For Performance Category 3 buildings, limiting displacements to the value at peak capacity is consistent with the behavior goals of this category. Therefore, for Performance Category 3, in-plane horizontal displacement of walls shall be limited to 0.5 inches. It is recognized that HCTW construction has significant capacity beyond the point at which maximum load is reached. However, behavior in this region is only consistent with Performance Category 1 or 2 buildings. For buildings in these lower categories, in-plane horizontal displacement is permitted out to 0.75 inches provided that maximum load is limited to $75 \%$ of the level given by Equation 7-13.

Note that if maximum load per Equation $7-13$ is reached in a wall element prior to reaching the maximum limit displacement, it is permissible to reduce the stiffness of that element by some rational approach and re-run the demand calculation allowing redistribution of loads to other elements. The limit state by these criteria is reached when the element reaches the limit displacement or other elements are not able to resist the increased loads from the redistribution.

\subsection{OUT-OF-PLANE HCTW INERTIA CAPACITY \& LIMIT DISPLACEMENTS}

\subsubsection{Response to Out-of-Plane Inertia Loads}

The out-of-plane capacity for inertial may be estimated from the prediction equation presented in Reference 46.

$$
\mathrm{q}=0.8 * \mathrm{t}^{2} *\left[\alpha\left(\mathrm{f}_{\text {m-paralles }}^{\prime}\right)^{0.75} / 1^{2.5}+\beta\left(\mathrm{f}_{\text {m-normal }}^{\prime}\right)^{0.75} / \mathbf{h}^{\prime 2.5}\right]
$$

where $\mathrm{q}$ is the median uniform out-of plane pressure capacity in psi of a wall which is primarily acting in two way action spanning horizontally and vertically, $\mathrm{f}_{\mathrm{m} \text {-paralle }}$ is the median masonry prism strength parallel to the masonry unit cells in psi, $\mathrm{f}_{\mathrm{m} \text {-normal }}$ is the median masonry prism strength normal to the masonry unit cells in psi, $t$ is the infill gross thickness in inches, $l '$ is the infill width in inches, $h^{\prime}$ is the infill height in inches, and $\alpha$ and $\beta$ are measures of the relative stiffness of the bounding columns and beam, respectively, as defined in Reference 46.

From the HCTW test program, observed behavior corresponded primarily to one-way action spanning vertically due to some slippage along the columns governing the maximum out-of-plane load. As a result, it is recommended that only the $\beta / h^{2.5}$ term be considered unless there is a mechanism to prevent column slippage. 
There is very limited test data for out-of-plane inertial loading such that it is not possible to develop factors of conservatism from the test data as was done for in-plane loading. It is judged that it is reasonable to utilize the same factors of safety for out-of-plane and in-plane loads such that out-of-plane capacity shall be defined by Equation 7-16 with $\Phi=2 / 3$ and $F_{M}=4 / 3$.

$$
\mathrm{q}=0.8 * \Phi *\left(\mathrm{f}_{\mathrm{m}}^{\prime} / \mathrm{F}_{\mathrm{M}}\right)^{0.75 * \mathrm{t}^{2} * \beta / \mathrm{h}^{\prime(2.5)} \leq 3 \mathrm{psi}}
$$

The maximum load capacity of $3 \mathrm{psi}$ is an empirical value to bound test results with low height to thickness ratios. Note that ${\mathrm{f}_{\mathrm{m}}^{\prime}}^{\prime}$ is $\mathrm{f}_{\mathrm{m} \text {-normal }}^{\prime}$ in the above equation.

\subsubsection{Out-of Plane Response to Story Drift}

Story drift limits from DOE-STD-1020-94 for buildings are about the same level as HCTW test displacement amplitude for which little wall distress was observed. It is judged that HCTW have considerable out of plane drift capacity beyond the drift limits from DOE-STD-1020-94.

\subsection{IN-PLANE AND OUT-OF-PLANE INTERACTION}

If the out-of-plane demand is less than $1 / 2$ the out-of-plane capacity, interaction with in-plane behavior need not be considered. Where interaction is considered, a linear interaction relation shall be used. 



\section{SUMMARY AND CONCLUSIONS}

\subsection{INDEPENDENT REVIEW SUMMARY}

Many of the existing buildings at the Oak Ridge Y-12 Plant are steel frame construction with unreinforced hollow clay tile infill walls (HCTW). The HCTW infill is counted on to provide lateral seismic resistance to the design/evaluation basis earthquake for the Oak Ridge site. However, acceptance criteria for this construction must be developed. The basis for the development of seismic criteria is the Oak Ridge HCTW testing and analysis program and the target performance goals of DOE 5480.28 and DOE-STD-1020-94. This report documents an independent review of the testing and analysis program and development of recommended acceptance criteria for Oak Ridge HCTW construction.

\subsection{ASSESSMENT OF OAK RIDGE HCTW TEST PROGRAM}

The HCTW Test Program included: (1) "Macro" Wall In-Plane and Out-of-Plane Tests (University of Tennessee); (2) "Full-Scale" Wall In-Plane and Out-of-Plane Tests (Iowa State University); (3) "In-Situ" Out-of-Plane Test (Y-12 Bldg. 9207); (4) Shake Table Tests (CERL); and (5) Masonry Component Tests (NIST, University of Tennessee, MMES). The tests were performed according to procedure and the data obtained was of high quality. All documentation is of high quality. Tests appear to adequately address inplane behavior of HCTW without openings. There are only very limited tests considering out-of-plane behavior and only one test of a particular opening configuration.

\subsection{SUMMARY OF IN-PLANE TESTS AND EVALUATION}

Based on the test program, an equivalent strut model has been developed to represent the stiffness of the HCTW infill. The strut stiffness is modified to follow the load deflection relation observed in tests through a procedure to evaluate the secant stiffness. Nineteen in-plane tests conducted under the HCTW program were reviewed to establish maximum test capacity and associated displacement using the average load and displacement (average of push and pull) obtained during the peak loading cycle. A prediction equation with parameters of effective masonry strength (geometric average of strength normal and parallel to the HCT cells) and wall thickness closely matches the test data. The behavior at capacity is governed by crushing of the HCT in a corner of the wall.

Equivalent damping from wall load-displacement hysteresis have been estimated to be on the order of $5 \%$ equivalent viscous damping. System damping used for seismic response analyses should be determined by adding the effective hysteretic damping to the elastic material damping. A value of $10 \%$ system damping is reasonable for HCTW buildings. 
The testing seems to support the contention that only the wall thickness contained within the steel frame is effective in creating an effective compressive strut.

It is recommend that only the steel column EI be considered as the effective EI of the pilaster in the evaluation of equivalent strut properties.

\subsection{SUMMARY OF OUT-OF-PLANE TESTS AND EVALUATION}

The behavior of walls to imposed out-of-plane drift and the behavior of walls with out-of-plane lateral loading was considered in the test programs. HCTW walls appear to be able to withstand story drifts on the order of $1 \%$ without any significant distress. A prediction equation from the literature appears to match the limited lateral loading tests performed.

\subsection{SEISMIC EVALUATION CRITERIA FOR HCTW BUILDINGS}

Recommended seismic evaluation criteria for Oak Ridge $Y-12$ buildings are presented in Section 2. 


\section{REFERENCES}

1. “Structural Modeling of HCTW Infills,” Martin Marietta Energy Systems, Inc., Appendix A, March 6, 1995.

2. R.D. Flanagan, M.A. Tenbus, R.M. Bennett, "Numerical Methods for Analysis of Clay Tile Infills," Martin Marietta Energy Systems, Inc., 4th Annual DOE Natural Phenomena Hazards Mitigation Conference, Atlanta, GA., Y/EN-5139, Oct. 19-22, 1993, Oct. 1993.

3. R.D. Flanagan, M.A. Tenbus, R.M. Bennett, "Uniform Lateral Load Capacity of Infilled Frames," Martin Marietta Energy Systems, Inc., ASCE Structures Congress '94, Atlanta, GA., April, 1994, Y/EN-5137, Oct. 1993.

4. R.C. Henderson, W.D. Jones, E.G. Burdette, M.L. Porter, "The Effect of Prior Out-of-Plane Damage on the In-Plane Behavior of Unreinforced Masonry Infilled Frames," Martin Marietta Energy Systems, Inc., 4th Natural Phenomena Hazards Mitigation Conference, Atlanta, GA., Oct. 19-22, Y/EN-5073, 1993, Aug. 25, 1993.

5. R.D. Flanagan, R.M. Bennett, "Large-Scale Testing of Structural Clay Tile Infilled Frames," Martin Marietta Energy Systems, Inc., 1993 Annual Conference of the Canadian Society of Civil Engineers, Fredericton, New Brunswick, Canada, June, 1993, Y/EN-4909, Mar. 18, 1993.

6. R.D. Flanagan, R.M. Bennett, G.A. Barclay, "In-Plane Behavior and Strength of Structural Clay Tile Infilled Frames," Martin Marietta Energy Systems, Inc., 6th Annual North American Masonry Conference, Philadelphia, PA., June, 1993, Y/EN-4857, Feb. 2, 1993.

7. R.D. Flanagan, R.M. Bennett, M.B. Butala, "Properties of Structural Clay Load-Bearing Wall Tile," Martin Marietta Energy Systems, Inc., 6th North American Masonry Conference, Philadelphia, PA., June, 1993, Y/EN-4856, Feb. 2, 1993.

8. R.D. Flanagan, R.M. Bennett, "Inter-Story Drift Effects on the In-Plane Capacity of Infilled Frames," Martin Marietta Energy Systems, Inc., Third International Masonry Conference, London England, October, 1992, Y/EN-4729, Aug. 4, 1992. 
9. R.D. Flanagan, J.E. Beavers, R.E. Bennett, "Seismic Behavior of Unreinforced Hollow Clay Unfilled Tiles," Martin Marietta Energy Systems, Inc., ASTM Symposium on Masonry: From Design and Construction to Problems and Repair, Miami, FL., Dec. 8, 1992, Y/EN-4651, May 4,1992

10. R.C. Henderson, W.D. Jones, M.L. Porter, "Out-of-Plane and In-Plane Testing of Reinforced Masonry Infills," Martin Marietta Energy Systems, Inc., ASCE Structures Congress '93, Irvine, CA., Apr. 12-21, 1993, Y/EN-4616, Sept. 30, 1992.

11. B.D. Jamal, R.M. Bennett, R.D. Flanagan, "Numerical Analysis for In-Plane Behavior of Unfilled Frames, Martin Marietta Energy Systems, Inc., 6th Canadian Masonry Symposium Saskatoon, Saskatchewan, Canada, June 15-17, 1992, Y/EN-4603, Feb. 27, 1992.

12. R.D. Flanagan, R.M. Bennett, G.A. Barclay, "Experimental Testing of Hollow Clay Tile Infilled Frames," Martin Marietta Energy Systems, Inc., 6th Canadian Masonry Symposium Saskatoon, Saskatchewan, Canada, June 15-17, 1992, Y/EN-4372, Feb. 27, 1992.

13. K.E. Fricke, W.D. Jones, "A Test Program to Determine the Structural Properties of Unreinforced Hollow Clay Tile Masonry Walls at the DOE Oak Ridge Plants," Martin Marietta Energy Systems, Inc., The Masonry Society Journal, Vol. 9 No. 2, Feb. 1991, pp. 56-63. (also in 5th North American Masonry Conference Proceedings), K/D-5834 R1, March 1991.

14a. R.M. Bennett, E.G. Burdette, D.W. Goodpasture, "Testing of Clay Tile Infilled Frames," Y/EN4764 (in ES/CNPE-93/1), Unreinforced Hollow Clay Tile Workshop, San Francisco, CA., Sept. 21-22, 1992, Sept. 21, 1992.

14b. R.D. Flanagan, M.A. Tenbus, R.M. Bennett, B.D. Jamal, "Behavior of Infilled Frames," Y/EN4765 (in ES/CNPE-93/1), Unreinforced Hollow Clay Tile Workshop, San Francisco, CA., Sept. 21-22, 1992, Sept. 21, 1992.

15. D.P Abrams, S.A. Adham, J.C. Kariotis, J.L. Noland, “Independent Consultants' Report on Workshop for Review of MM-ES HCTW Testing Program: April 13 \& 14, 1993, Oak Ridge, Tennessee," Atkinson-Noland \& Associates, Inc., Draft, May 19, 1993. 
16. R.C. Henderson, "Experimental \& Analytical Investigation of Infilled and Out-of-Plane Seismic Drift in Unreinforced Masonry Infilled Frames," PhD Dissertation, Aug. 1994.

17. R.M. Bennett, R.D. Flanagan, "Test Procedures for Laboratory Combined Static In-Plane and Out-of-Plane Testing of Full Scale Hollow Clay Tile Infilled Frames: Test Frame Number 1," Martin Marietta Energy Systems, Inc., HCTP-7-1 R/1, Feb. 28, 1992.

18. R.M Bennett, R.D. Flanagan, "Test Procedures for Laboratory Combined Static In-Plane and Outof-Plane Testing of Full-Scale Hollow Clay Tile Infilled Frames: Test Frame Number 5", HCTP7-5 R/2, July 9, 1992.

19. R.M. Bennett, R.D. Flanagan, "Test Procedure for Laboratory Combined Static In-Plane and Outof-Plane Testing of Full Scale Hollow Clay Tile Infilled Frames: Test Frame Number 11," HCTP7-11 R/1, Feb. 28, 1992.

20. R.M. Bennett, R.D. Flanagan, " Test Procedure for Laboratory Combined Static In-Plane and Outof-Plane Testing of Full Scale Hollow Clay Tile Infilled Frames: Test Frame Number 2," HCTP7-2, Jan. 2, 1992.

21. R.M. Bennett, R.D. Flanagan, "Test Procedure for Laboratory Combined Static In-Plane and Outof-Plane Testing of Full Scale Hollow Clay Tile Infilled Frames: Test Frame Number 3," HCTP-73, Dec. 11, 1991.

22. R.M. Bennett, R.D. Flanagan, "Test Procedure for Laboratory Combined Static In-Plane and Outof-Plane Testing of Full Scale Hollow Clay Tile Infilled Frames: Test Frame Number 4," HCTP-74 R/0, July $9,1992$.

23. Same as Number 18

24. R.M. Bennett, R.D. Flanagan, "Test Procedure for Laboratory Combined Static In-Plane and Outof-Plane Testing of Full Scale Hollow Clay Tile Infilled Frames: Test Frame Number 9, " HCTP-79, June 9, 1992. 
25. R.M. Bennett, R.D. Flanagan, "Test Procedure for Laboratory Combined Static In-Plane and Outof-Plane Testing of Full Scale Hollow Clay Tile Infilled Frames: Test Frame Number 10," HCTP7-10 R/1, May 7, 1992.

26. Same as Number 25

27. R.M. Bennett, R.D. Flanagan, "Test Procedure for Laboratory Combined (Static In-Plane and Out-of-Plane Testing of Full Scale Hollow Clay Tile Infilled Frames: Test Frame Number 21," HCTP-7-21 R/1, May 7, 1993.

28. R.M. Bennett, R.D. Flanagan, "Test Procedure for Laboratory Combined Static In-Plane and Outof-Plane Testing of Full Scale Hollow Clay Tile Infilled Frames: Test Frame Number 18," HCTP7-18 R/1, Aug. 19, 1992.

29. R.M. Bennett, R.D. Flanagan, "Test Procedure for Laboratory Combined Static In-Plane and Outof-Plane Testing of Full Scale Hollow Clay Tile Infilled Frames: Test Frame Number 20, " HCTP7-20 R/1, Sept. 29, 1992.

30. R.M. Bennett, R.D. Flanagan, "Test Procedure for Laboratory Combined Static In-Plane and Outof-Plane Testing of Full Scale Hollow Clay Tile Infilled Frames: Test Frame Number 17," HCTP7-17, May 18, 1992.

31. R.M. Bennett, R.D. Flanagan, "Test Procedure for Laboratory Combined Static In-Plane and Outof-Plane Testing of Full Scale Hollow Clay Tile Infilled Frames: Test Frame Number 13," HCTP7-13 R/1, May 18, 1992.

32. R.M. Bennett, R.D. Flanagan, “Test Procedure for Laboratory Combined Static In-Plane and Outof-Plane Testing of Full Scale Hollow Clay Tile Infilled Frames: Test Frame Number 7," HCTP-77 R/1, May 18, 1992.

33. Same as 29 
34. R.M. Bennett, R.D Flanagan, "Test Procedure for Laboratory Combined Static In-Plane and Outof-Plane Testing of Full Scale Hollow Clay Tile Infilled Frames: Test Frame Number 19," HCTP7-19, Sept. 29, 1992.

35. Same as 27

36. R.M. Bennett, R.D. Flanagan, "Test Procedure for Laboratory Combined Static In-Plane and Outof-Plane Testing of Full Scale Hollow Clay Tile Infilled Frames: Test Frame Number 23,” HCTP7-23 R/1, Dec. 12, 1992.

37. R.M. Bennett, R.D Flanagan, "Test Procedure for Laboratory Combined Static In-Plane and Outof-Plane Testing of Full Scale Hollow Clay Tile Infilled Frames: Test Frame Number 22," HCTP$7-22$, Oct. $15,1992$.

38. R.M. Bennett, R.D Flanagan, "Test Procedure for Laboratory Combined Static In-Plane and Outof-Plane Testing of Full Scale Hollow Clay Tile Infilled Frames: Test Frame Number 24," HCTP7-24, July 8, 1993.

39. R.D. Flanagan, R.M. Bennett, "Technical Overview of the Hollow Clay Tile Evaluation Program,” Y/EN-4326 CNPE/HCT-1, Oct. 31, 1991.

40. R.C Henderson, W.D. Jones, M.L. Porter, "Factors Affecting the Ductility of Double-Wythe Masonry Infills Subjected to Seismic Drift," Y/EN-4685, 6th North American Masonry Conference, Philadelphia, PA., June, 1993, Feb. 11, 1993.

41. R.D. Flanagan, R.M. Bennett, "Structural Testing of Hollow Clay Tile Units - Volume 1," Y/EN4536/V1, Aug. 5, 1992.

42. J. Ben-Hassine, E.C. Drumm, "In-Plane Analysis of Hollow Clay Tile Infilled Frames: Effect of Wall-Frame Interface \& Connection Rigidity," Y/EN-4124/P8, Sept., 1990.

43. S.N. Clarke, R.M. Bennett, "Literature Review of Shake Table Testing or Masonry Structures," Y/EN-4600, Sept., 1991. 
44. C.E. Columber, "Structural Clay Tile Component Behavior," Y/EN-5309, Dec. 18, 1994.

45. J.J. Fowler, "Analysis of Dynamic Testing Performed on Structural Clay Tile", Y/EN-5310, Dec., 1994.

46. R.D. Flanagan, "Behavior of Structural Clay Tile Infilled Frames," Y/EN-5110, Dec., 1994.

47. R. Kroon, “9212 Headhouse Area Walkdown," SAIC 93-1002, Apr. 1993 (including 23 Building 9212 Drawings).

48. K.E. Fricke, T.E. Huff, “Test Procedure of the Out-of-Plane Full Scale Air Bag Test of a Hollow Clay Tile Wall Panel at the Y-12 Plant - Building 9207," HCTP-21, Sept. 20, 1991.

49. HCTWP21CHK, "Checklist for Airbag Test."

50. T.E. Huff, K.E. Fricke, W.D. Jones, "Report of the Building 9207 Air Bag Test," Y/EN-4585, Dec., 1992.

51. L.S. Chua, "Out-of-Plane Behavior of Unreinforced Hollow Clay Tile Masonry Infilled Wall Panels”, MS Thesis, The University of Tennessee, Knoxville, Y/EN-4278, June 26, 1991.

52. J.W. Dawe, C.K. Seah, "Behavior of Masonry Infilled Steel Frames," Canadian Journal of Civil Engineering, 16, 865-876, 1989a.

53. J.L. Dawe, C.K. Seah, "Out-of-Plane Resistance of Concrete Masonry Infilled Paneis," Canadian Journal of Civil Engineering, 16, 854-864, $1989 \mathrm{~b}$.

54. M. Holmes, “Steel Frames with Brickwork and Concrete Infilling,' Proceedings of the Institution of Civil Engineers, 19, 473-478, 1961.

55. M. Holmes, "Combined Loading on Infilled Frames," Proceedings of the Institution of Civil Engineers, 25, 31-38, 1963. 
56. T.C. Liauw, K.H. Kwan, "Plastic Theory of Non-Integral Infilled Frames," Proceedings of the Institution of Civil Engineers, 75, 379-396, 1983.

57. B. Stafford-Smith, "Lateral Stiffness of Infilled Frames," Journal of the Structural Division, ASCE, 88 (ST6), 183-199, 1962.

58. B. Stafford-Smith, "Behavior of Square Infilled Frames," Journal of the Structural Division, ASCE, 92 (ST1), 381-403, 1966.

59. B. Stafford-Smith, "Model Tests of Vertical and Horizontal Loading of Infilled Frames," Journal of the American Concrete Institute, 65 (8), 618-624, 1968.

60. B. Stafford-Smith, C. Carter, "A Method for the Analysis of Infilled Frames," Proceedings of the Institution of Civil Engineers, 44, 31-48, 1969.

61. R.H. Wood, "Plasticity, Composite Action and Collapse Design of Unreinforced Shear Wall Panels in Frames," Proceedings of the Institution of Civil Engineers, Part 2, 65, 381-411, 1978.

62. R.D. Flanagan, R.M. Bennett, "Seismic Evaluation of Industrial Facilities with Unreinforced Structural Clay Tile Infills,” Fifth U.S. National Conference on Earthquake Engineering, Chicago, IL., 365-474, 1994a.

63. C.W. Yancey, "Hollow Clay Tile Prism Tests for Martin Marietta Energy Systems - Task 2 Testing," NIST, Y/EN-5083, Oct., 1993.

64. K.A. Boyd, "Compressive Strength and Constitutive Behavior of Clay Tile Prisms," MS Thesis, University of Tennessee, Knoxville, May 1993.

65. H.C. Plummer, "Brick and Tile Engineering," Brick Institute of America, Reston, VA., 1962.

66. “Test Specimen Frame Drawing, Test 9," University of Tennessee, Aug., 1991. 
67. M.B. Butala, W.D. Jones, "Material Properties of Hollow Clay Tile and Existing Mortar Characterization Study," Martin Marietta Energy Systems, Inc., 4th Annual Department of Energy Natural Phenomena Hazards Mitigation Conference, Oct. 1993, Y/EN-4687.

68. D.P. Abrams, "Proceedings from the NCEER Workshop on Seismic Response of Masonry Infills," National Center for Earthquake Research, State University of New York at Buffalo, Mar. $1,1994$.

69. I.M. May, S.Y.A. Ma, "A Rigid Plastic Method for the Determination of Collapse Loads of Infilled Panels with Openings," Journal of Strain Analysis, Vol. 20, No. 1, 1985.

70. K.A. Amos, "The Shear Strength of Masonry Infilled Steel Frames," Thesis, University of New Brunswick, May 1985.

71 J.L. Dawe, A.B. Schriver, C. Sofocleous, "Masonry Infilled Steel Frames Subject to Dynamic Loads," Can. J. Civ. Eng. Vol. 16, 877-885, 1989.

72. C.K Seah, "Out-Of-Plane Behavior of Concrete Masonry Infilled Panels," Thesis, University of New Brunswick Aprii, 1988.

73. K.E. Fricke, R. D. Flanagan, "Compressive Strength of Masonry for the Oak Ridge Y-12 Plant Hollow Clay Tile Walls,” Martin Marietta Energy Systems, Inc., Y/EN-5346, April 17, 1995.

74 R. D. Flanagan, Telephone Communication, March 17, 1995. 


\section{APPENDIX A}

DETERMINATION OF MAXIMUM TEST DISPLACEMENT ASSOCIATED WITH MAXIMUM LOADING 

EQ E INTERNATIONAL

SHEET NO. $1 / 10$

ONO. $\$ 2281.06 \mathrm{HOB}$ HCTW Review BY $K L m$ DATE $3 / 21 / 95$ CALC NO. AREA SUBJECT TEST LOADS T DIsplacementsCHKD DATE

Ref. 16 \& 46 provide complete hysteresis, Pud., for each in-plane test. Both references: resign the peak load reached during the test as the test capacity. Since the reversed cycle capacity should gored under seismic, loading, the average test load obtained during push/ pull cycling of the test specimen in the vicinity of e peak lading and f prow to degrading behavior is, viewed as, the appropriate capacity to be reported. Further, Ls done in Ref the, the pet panel capacity, is the load to be used to evaluate the masonry capacity:

$$
P_{N E T}=P_{\text {TEST }}-\text { P FrAME }
$$

WHERE PFRAUE = KFrame $\delta$

Ref.46 Table 5.1 gives frame obtained from post -test loading $\%$ the bare frame and Ref. $16, F_{19} 103$ indicates that the final stiffness of the Is U wall/frame was approx $7 \mathrm{k} / \mathrm{m}$. This is assumed to be due to frame only,

Based on review of the hysteresis plot of each test, the following table tabulate: the estimated net push (- -1 it Pull panel loads and the associated. Ais placement.

A.1 
in-plane Net Panel Capacities and Limit Displacements

\begin{tabular}{|c|c|c|c|c|c|c|c|}
\hline & & Capacity & Displacement & Capacity & Displacement & Capacity & Displacement \\
\hline & Test No. & P-net (-) & $0(-)$ & $P$-net (t) & $\mathrm{d}(+)$ & P-net (avg) & $d$ (avg) \\
\hline \multirow{14}{*}{$\begin{array}{c}\text { In-Plane } \\
\text { Only }\end{array}$} & 1 & 27.0 & 1.08 & 36.9 & 0.77 & 32.0 & 0.93 \\
\hline & 2 & 35.2 & 1.10 & 38.9 & 108 & 37.1 & 1.09 \\
\hline & 3 & 31.3 & 0.67 & $\overline{34.5}$ & 0.57 & 32.9 & 0.62 \\
\hline & 4 & 48.3 & 0.86 & $\overline{31.6}$ & 0.68 & 40.0 & 0.77 \\
\hline & 5 & 39.5 & 0.62 & 33.4 & 0.57 & 36.5 & 0.60 \\
\hline & 7 & $\underline{29.6}$ & 0.84 & 27.4 & 0.73 & 28.5 & 0.79 \\
\hline & 9 & $\overline{40.4}$ & 0.45 & 38.0 & 0.53 & 39.2 & 0.49 \\
\hline & $10 a$ & 38.6 & 0.97 & 26.3 & 0.84 & 32.5 & 0.91 \\
\hline & $10 \mathrm{~b}$ & $\overline{30.3}$ & 1.10 & 31.0 & 0.90 & 30.7 & 1.00 \\
\hline & 17 & 44.9 & 1.22 & $\overline{39.9}$ & 1.62 & 42.4 & 1.42 \\
\hline & $21 a$ & $\overline{35.0}$ & 1.48 & $\$ 1.6$ & 1.31 & 38.3 & 1.40 \\
\hline & $21 b$ & 33.3 & 1.44 & $\overline{25.8}$ & $\$ 24$ & 29.6 & 1.34 \\
\hline & 24 & 13.0 & 0.76 & 27.7. & 0.64 & $27.7 / 13$ & 0.70 \\
\hline & $w 2$ & 80.1 & 0.76 & 50.3 & 1.00 & 55.2 & 0.88 \\
\hline Out-of-Plane & 11 & 32.9 & 0.42 & 32.3 & 0.62 & 32.6 & 0.52 \\
\hline drift then & 13 & 40.2 & 0.75 & 35.9 & 0.66 & 38.1 & 0.71 \\
\hline In-plane & W1 & 58.6 & 0.82 & 40.8 & 1.00 & 49.7 & 0.91 \\
\hline Out-of-Plane & 20 & 39.6 & 0.71 & 29.5 & 0.73 & 34.6 & 0.72 \\
\hline $\begin{array}{l}\text { pressure then } \\
\text { In-plane }\end{array}$ & 23 & 21.9 & 0.56 & 18.2 & 0.56 & 20.1 & 0.56 \\
\hline
\end{tabular}

Notes:

Test 10a has 1 inch column gap such that test displacements are reduced by 1 inch Underlined capacities match values in table in Flanagan thesis

For Tests $24,11,13,20$, and 23, the frame stiffness of Test 2 was used

For Tests $W 1$ and $W 2$, frame stiffness of 7 kips/inch was used

Capacity is the net panel capacity equal to the test load minus the frame load

Shaded tests not used to develop wall criteria

Capacities are in kips, displacements are in inches 
Summary of In-Plane Capacities

\begin{tabular}{|c|c|c|c|c|c|c|c|c|}
\hline \multirow[t]{2}{*}{ Test } & \multicolumn{3}{|c|}{ Push Capacity } & \multicolumn{3}{|c|}{ Pull Capacity } & \multirow{2}{*}{$\begin{array}{c}\text { Bare Frame } \\
\text { Capacity } \\
\text { (k) }\end{array}$} & \multirow{2}{*}{$\begin{array}{c}\text { Net Panel } \\
\text { Capacity } \\
\text { (k) }\end{array}$} \\
\hline & $\begin{array}{l}\text { Load } \\
\text { (k) }\end{array}$ & $\begin{array}{l}\text { Disp } \\
\text { (in) }\end{array}$ & $\begin{array}{l}\text { Panel } \\
\text { "Strain" }\end{array}$ & $\begin{array}{l}\text { Load } \\
\text { (k) }\end{array}$ & $\begin{array}{l}\text { Disp } \\
\text { (in) }\end{array}$ & $\begin{array}{c}\text { Panel } \\
\text { "Strain" }\end{array}$ & & \\
\hline 1 & 27.4 & 1.08 & 0.0036 & 37.2 & 0.77 & 0.0031 & 0.3 & 36.9 \\
\hline 2 & 37.4 & 1.04 & 0.0024 & 41.2 & 1.08 & 0.0026 & 2.3 & 38.9 \\
\hline 3 & $35.5^{1}$ & $0.62^{1}$ & 0.0017 & $\underline{37.9}$ & 0.50 & 0.0022 & 3.4 & 34.5 \\
\hline 4 & $\underline{51.8}$ & 0.83 & 0.0018 & 34.5 & 0.68 & 0.0010 & 3.5 & 48.3 \\
\hline 5 & 43.7 & 0.53 & 0.0013 & 37.9 & 0.57 & 0.0012 & 4.2 & 39.5 \\
\hline 7 & 31.4 & 0.84 & 0.0014 & 29.0 & 0.73 & 0.0010 & 1.8 & 29.6 \\
\hline 9 & 49.7 & 0.45 & --- & 46.9 & 0.43 & 0.0015 & 9.3 & 40.4 \\
\hline $10 a$ & 45.8 & 1.97 & 0.0035 & 32.5 & 1.84 & 0.0010 & 7.2 & 38.6 \\
\hline $10 \mathrm{~b}$ & 34.1 & 1.10 & 0.0038 & $\underline{34.3}$ & 0.90 & 0.0043 & 3.3 & 31.0 \\
\hline 17 & 48.2 & 1.22 & 0.0015 & 46.7 & 2.52 & 0.0021 & 3.3 & 44.9 \\
\hline $21 a$ & 40.4 & 1.48 & 0.0042 & $\underline{46.4}$ & 1.31 & 0.0031 & 4.8 & 41.6 \\
\hline $21 b$ & 38.6 & 1.44 & 0.0054 & 33.5 & 1.24 & 0.0042 & 5.3 & 33.3 \\
\hline 24 & 15.7 & 0.75 & 0.0010 & $\underline{30.0}$ & 0.64 & 0.0008 & 2.3 & 27.7 \\
\hline
\end{tabular}

$\begin{array}{ll}\pi & \frac{7}{8} \\ 0 & \frac{7}{0} \\ + & \frac{7}{2} \\ 0 & \frac{7}{y} \\ 0 & 7\end{array}$

$\frac{-1}{10}$

2

Peak load of $41.1^{k}$ recorded at 3.26 " during hydraulic control problem 


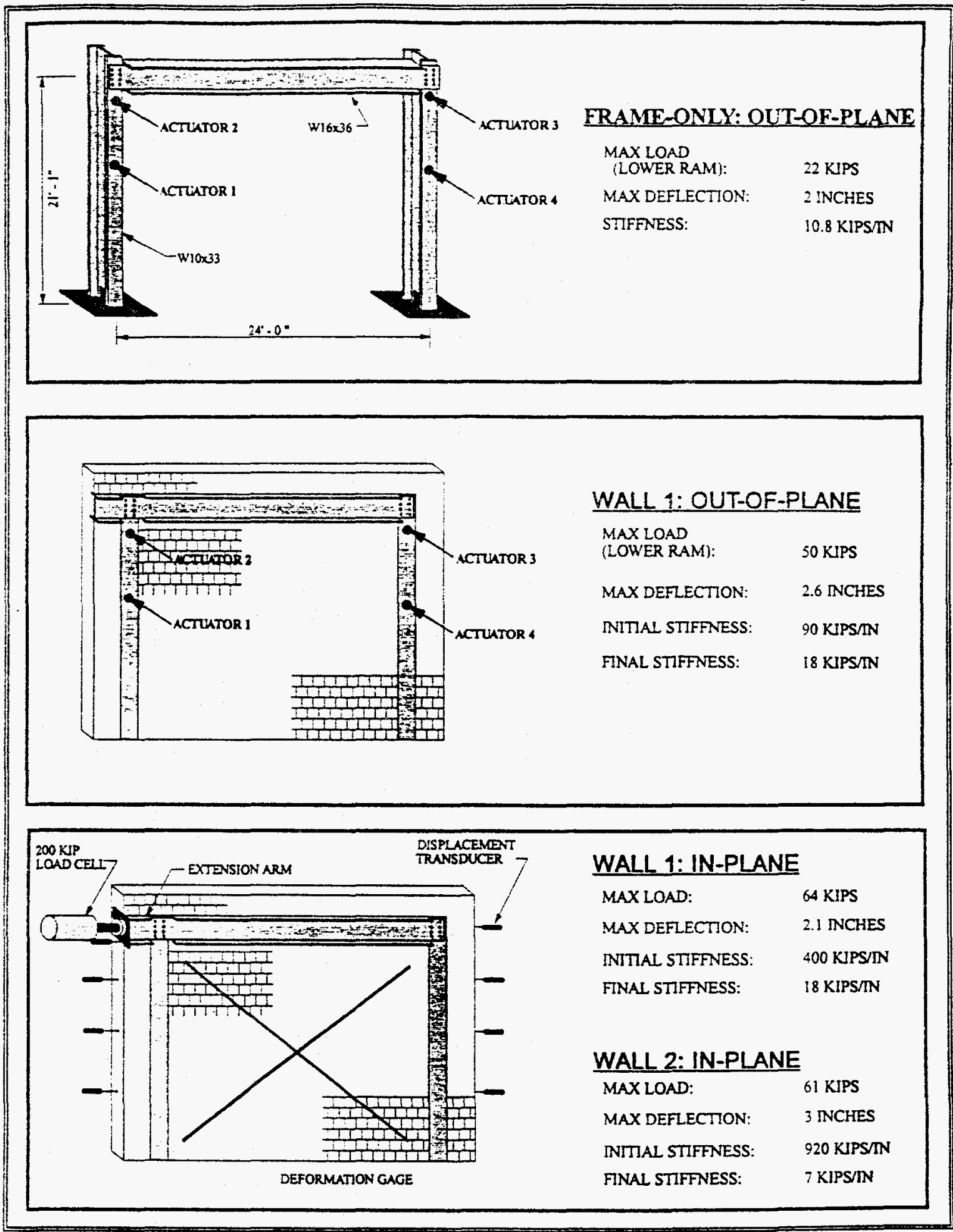

EIGURE 103. SUMMARY OF RESEARCH 
APPENDIX A

Ref. 46
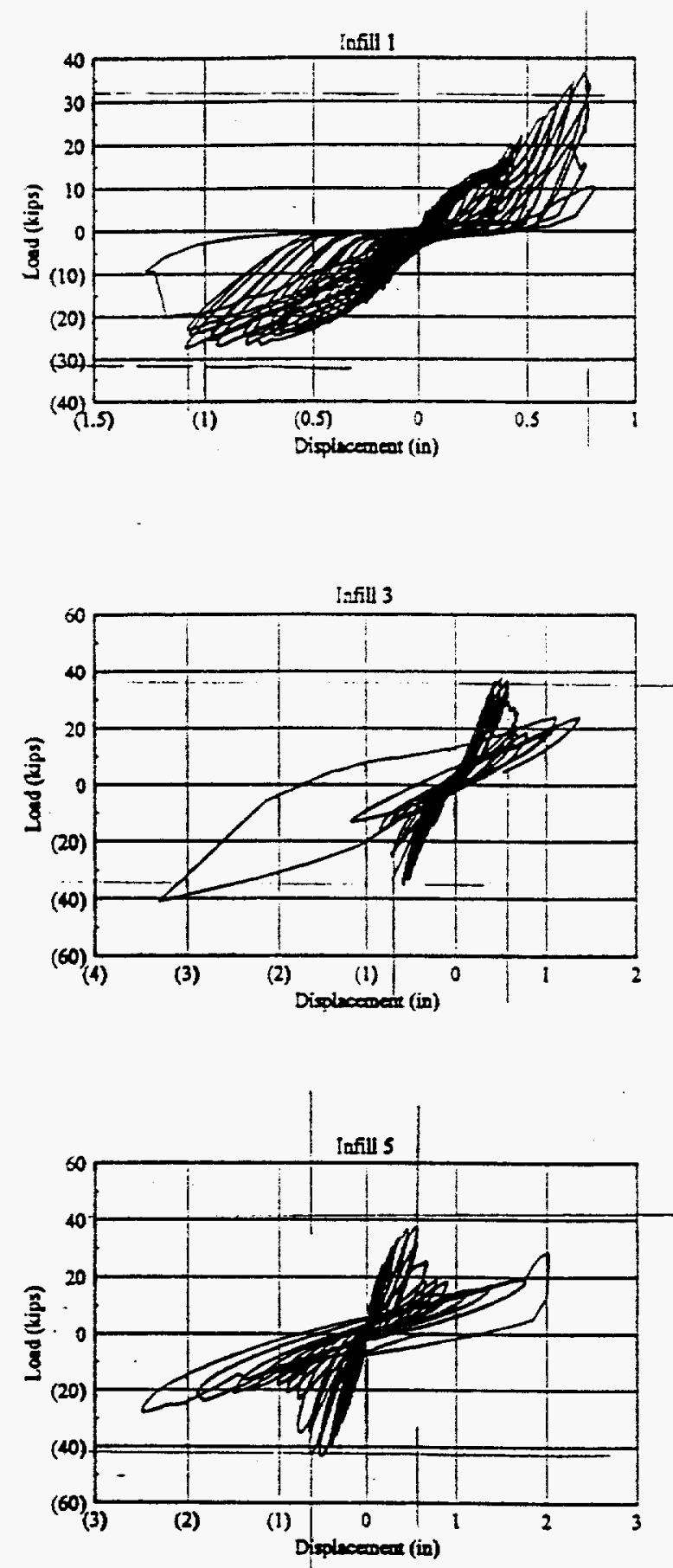

$5 / 10$
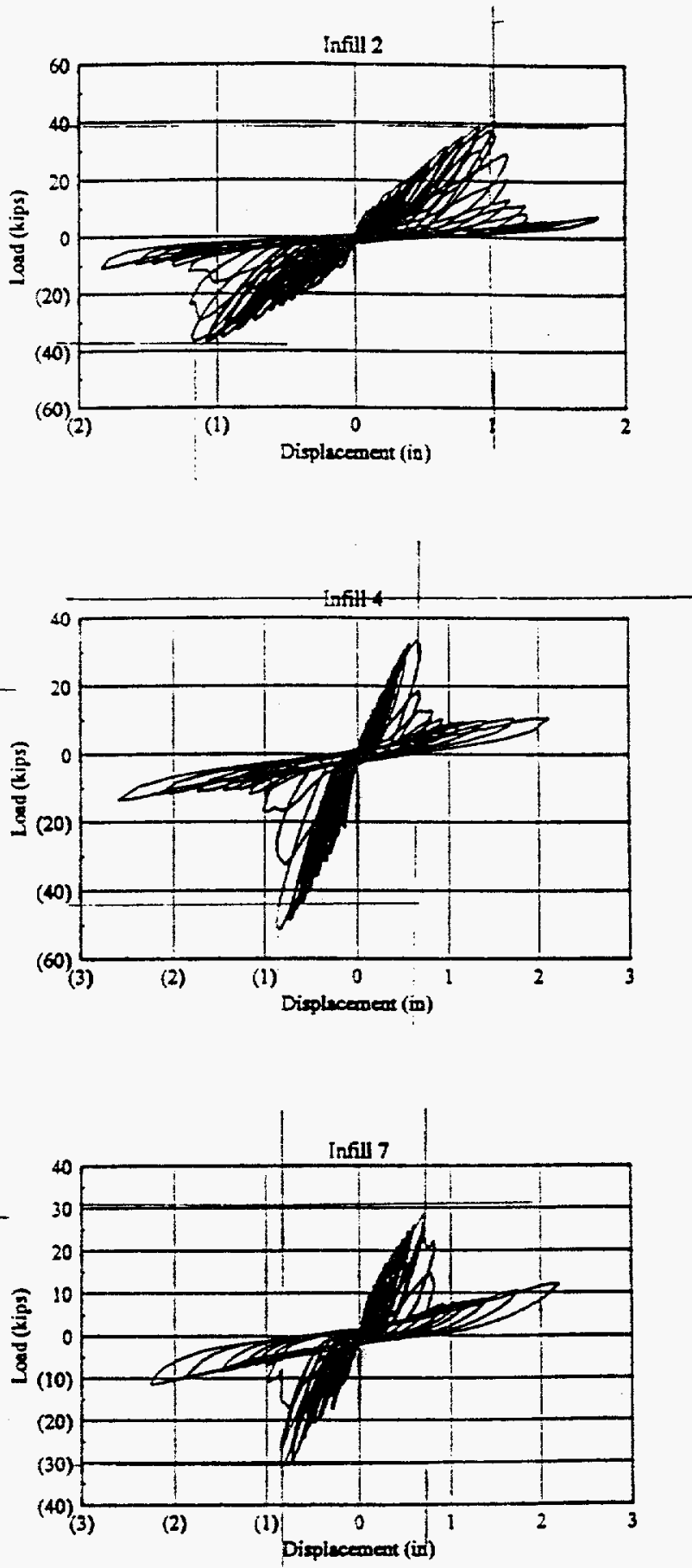

Figure 5.13 Infilled Frame In-Plane Hysteresis 
APPENDIX A

$$
\text { Ref. } 46
$$
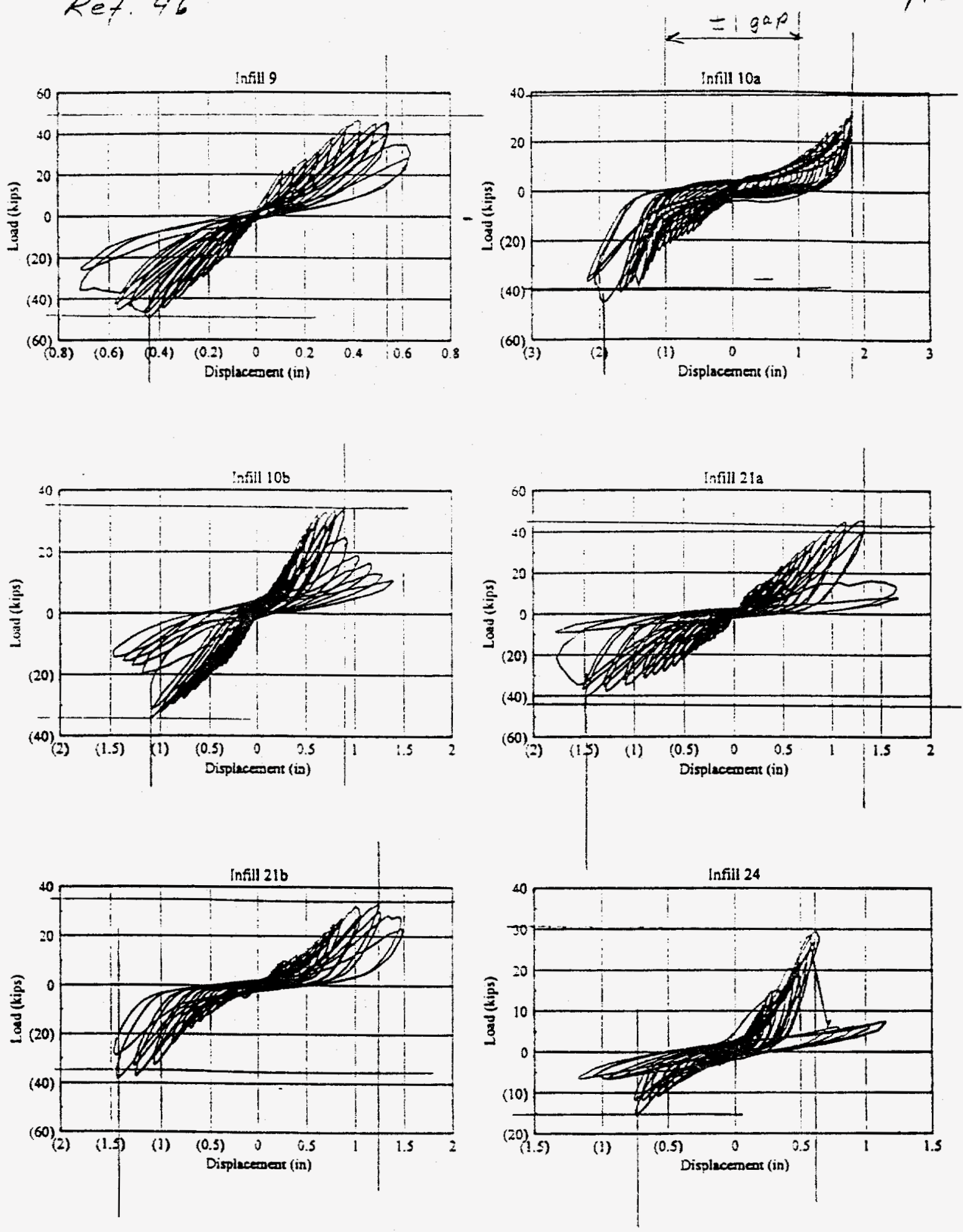

Figure 5.13 Continued 
APPENDIX A

Ref. 46

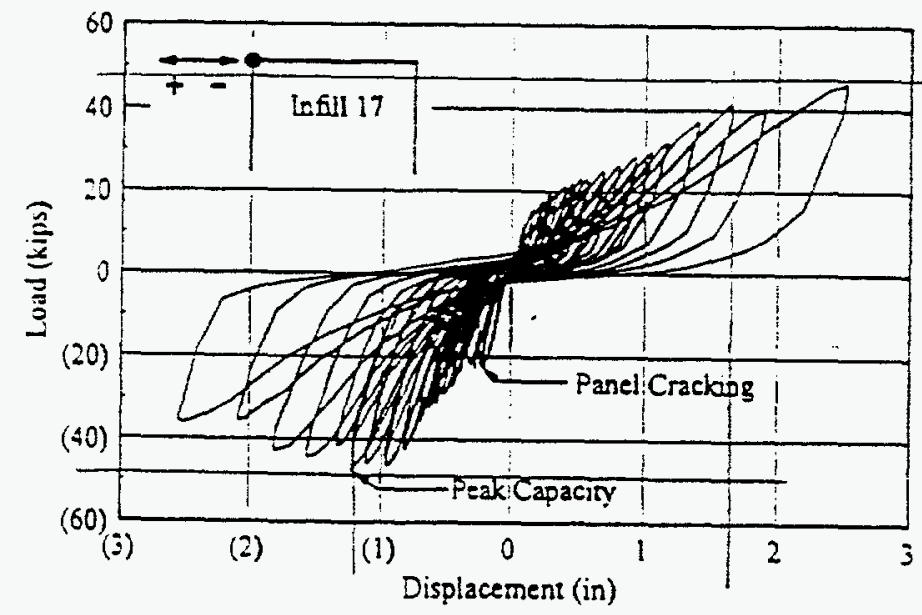

Figure 5.2 Complete Hysteresis of Specimen 17

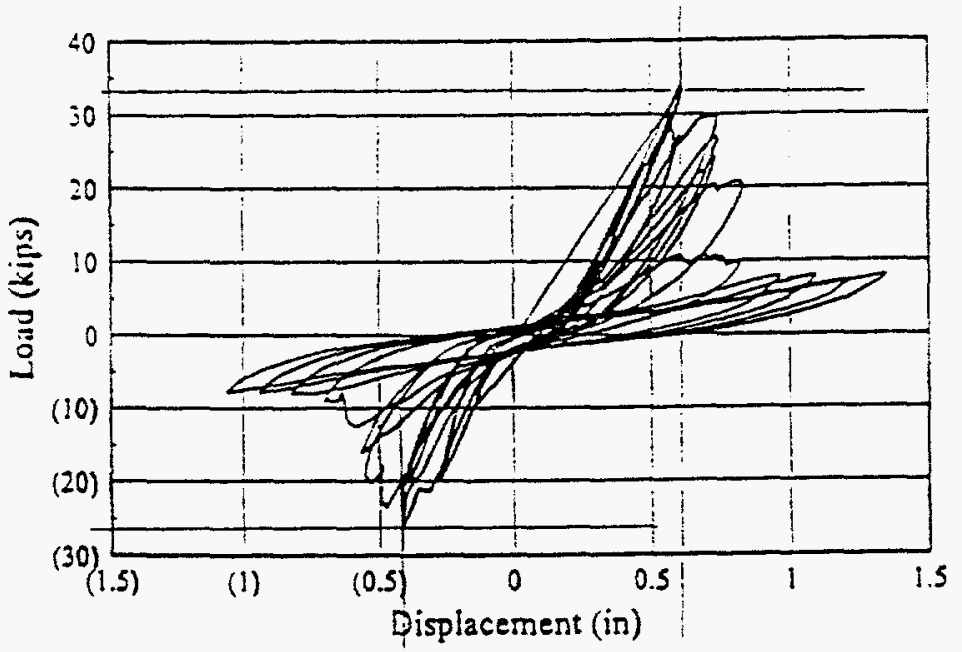

Figure 7.9 Specimen 11 In-Plane Loading

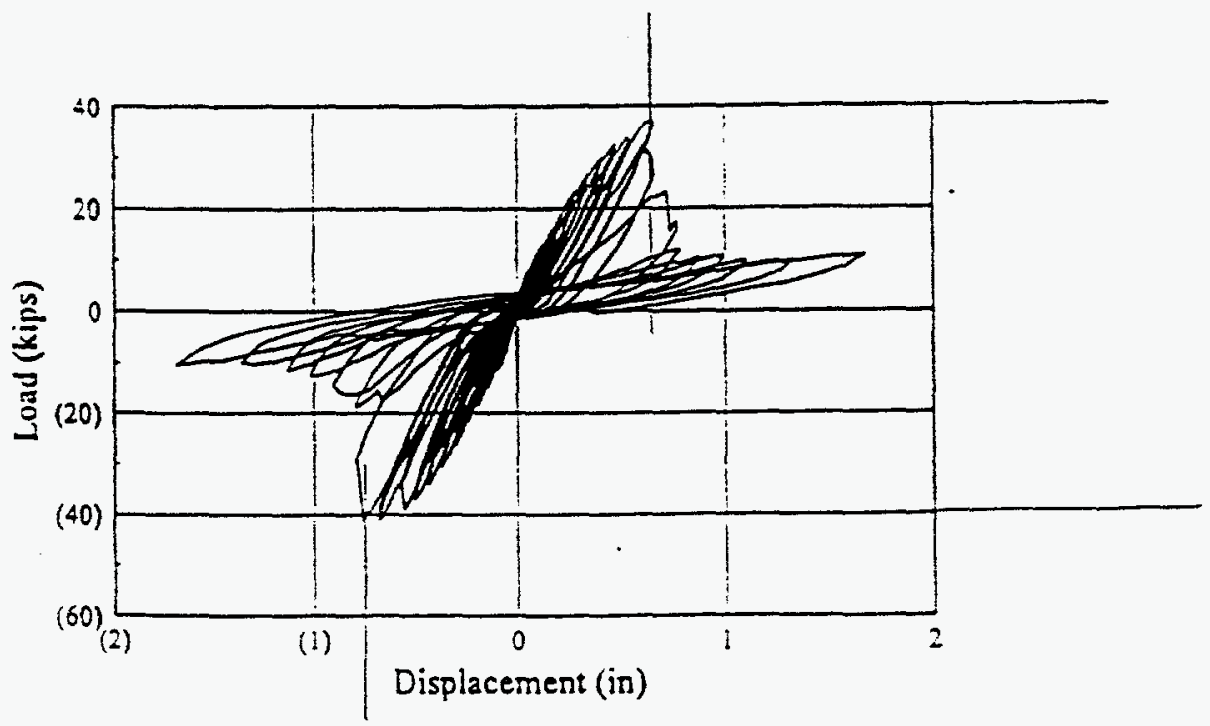

Figure 7.10 Specimen 13 In-Plane Loading 
APPENDIX A

Ret. 46

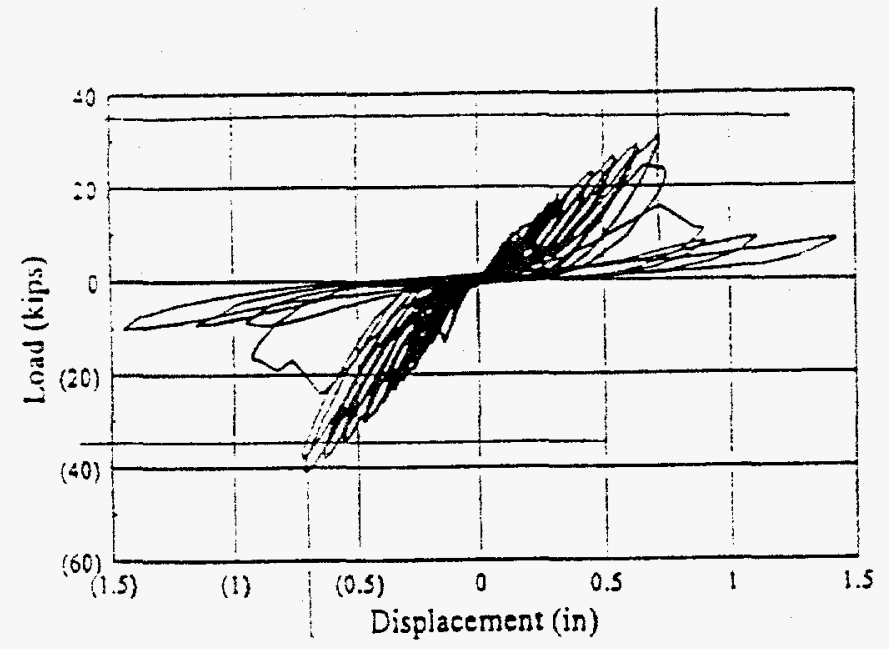

Eigure 7.16 Specimen 20 In-Plane Loading

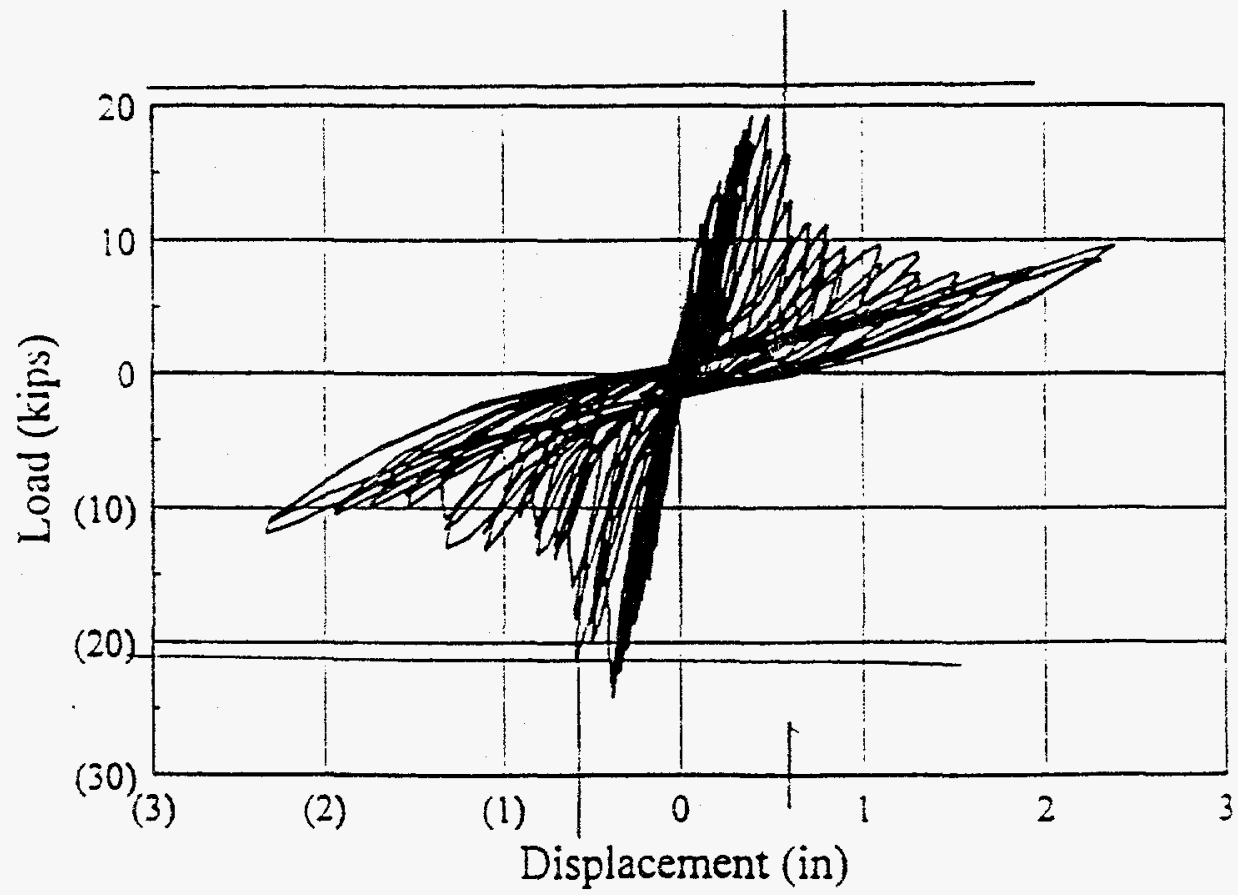

Figure 7.28 Specimen 23 In-Plane Hysteresis

A.8 
APPENDKX $\triangle$

Ref. 16

$9 / 10$

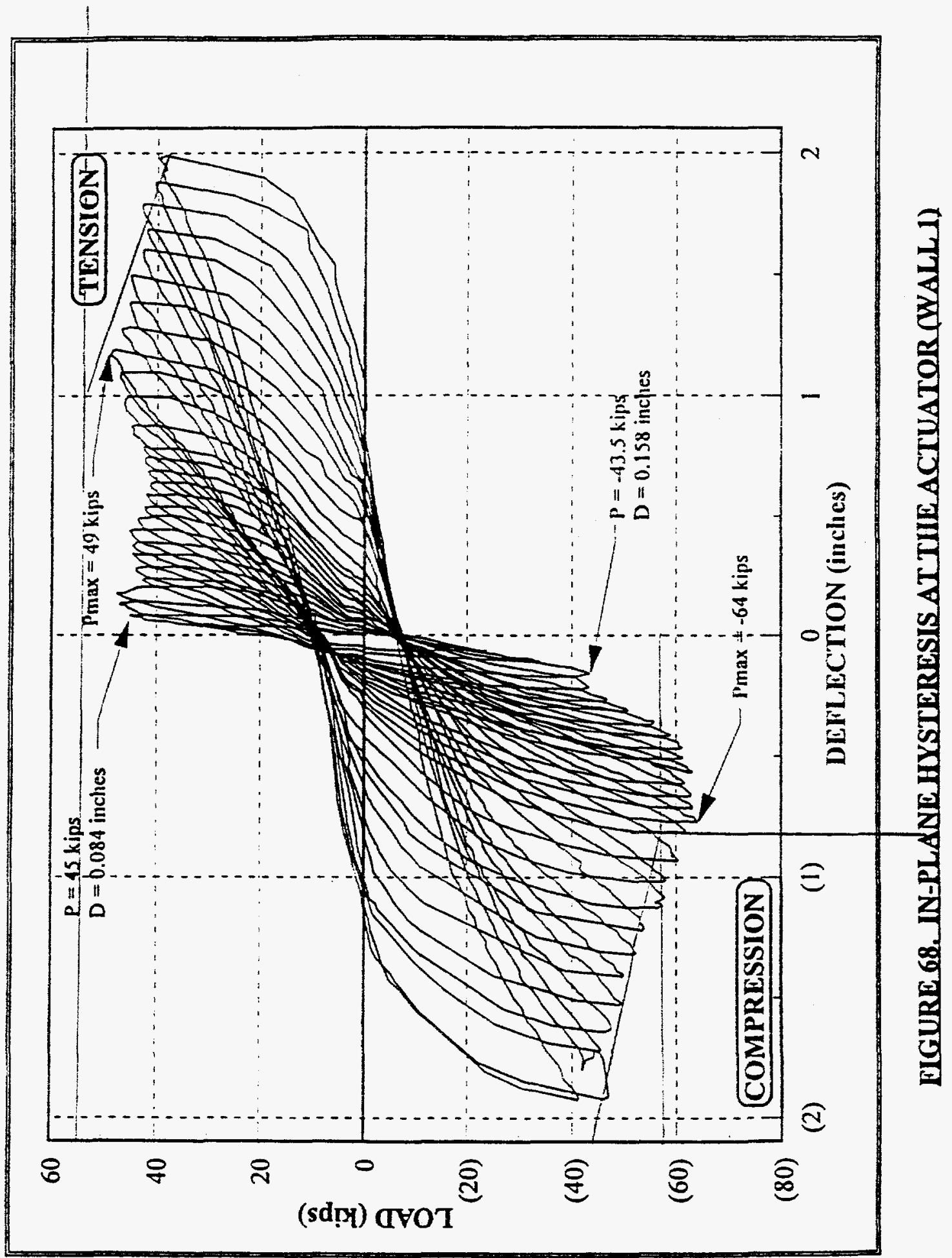


APPENDIX A

Rer. 16

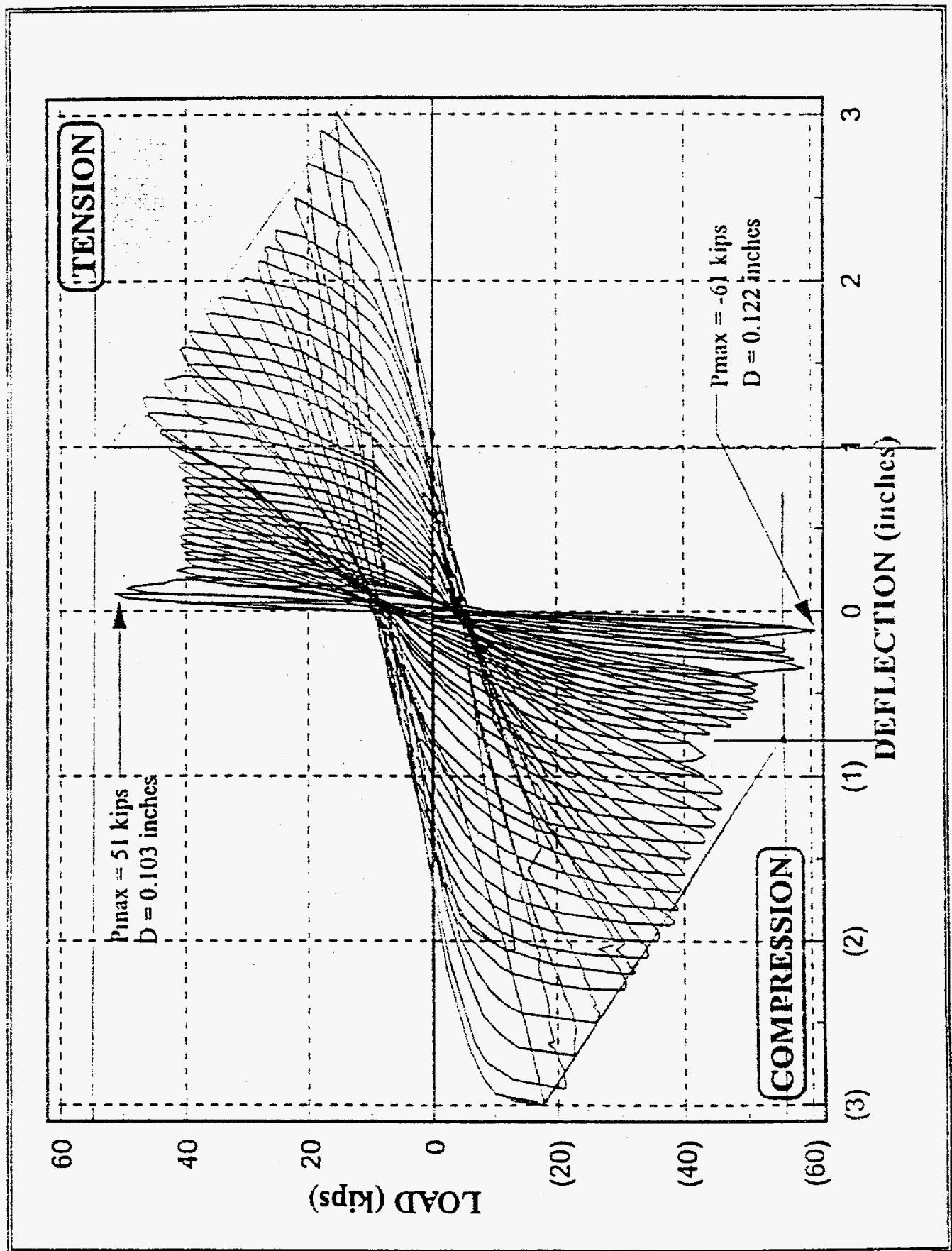

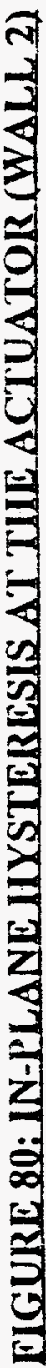


APPENDIX B

EVALUATION OF EQUIVALENT VISCOUS DAMPING FOR HYSTERETIC BEHAVIOR 
JOB NO. 92118.06 JOB

effective

BY $\angle \angle \mu$

SHEET NO. $\frac{1 / 3}{3 / 2 / 45}$

CALC. NO APP I SUBUEC energy disipation

CHK'D

DATE

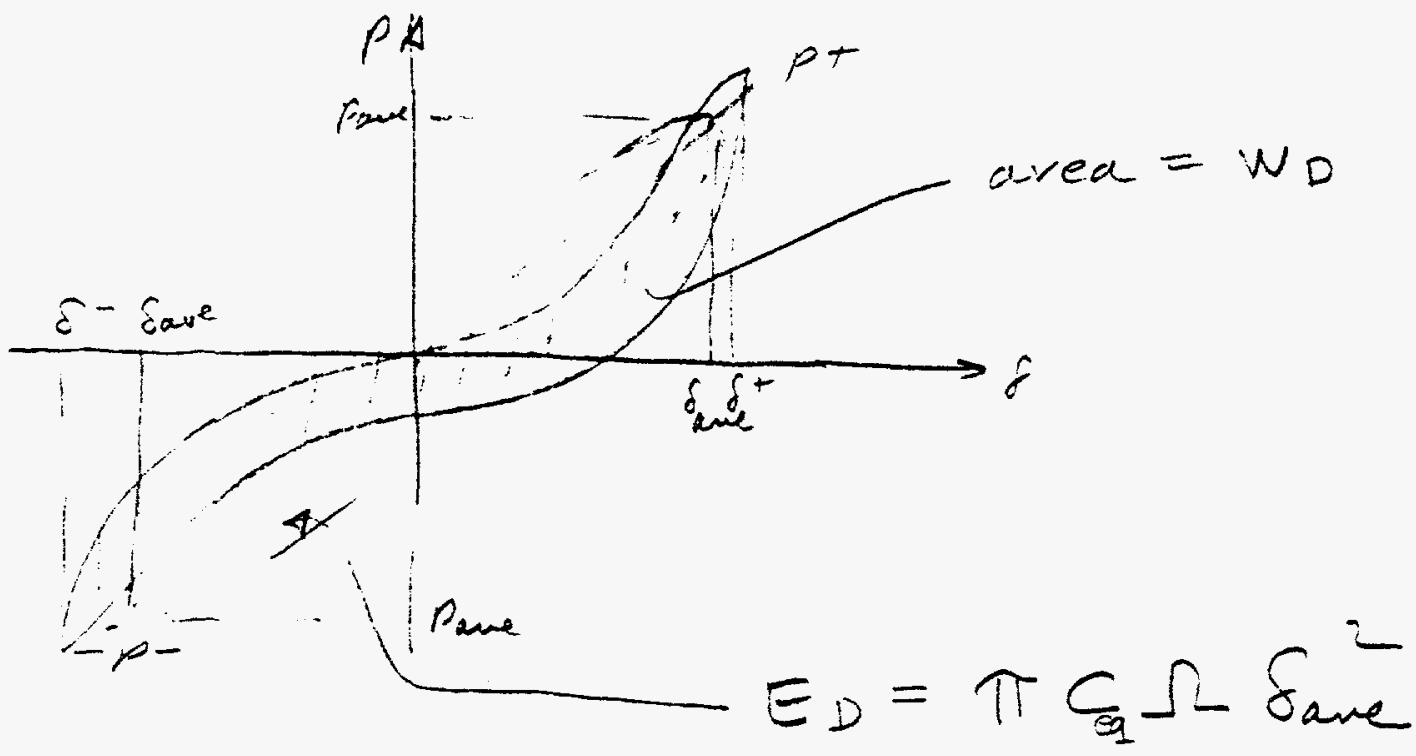

$$
C_{e q}=\frac{E D}{\pi \Omega \delta_{\text {ave }}^{2}}
$$

$\Omega=$ frequency@ which $E_{D}$ is determines

$$
\begin{aligned}
& \frac{c}{m}=2 \xi w_{n} \\
& \frac{k}{m}=w_{n}^{2} \\
& m=k / w_{n}=
\end{aligned}
$$

$\therefore \quad \sum_{\text {ex }}=\frac{c_{e q}}{m 2 w_{n}}=\frac{C_{e q}}{K / w_{n}^{2} w_{n}}$

$=\frac{\operatorname{seg}_{n}}{2 k}=\frac{E_{D}\left(\omega_{n}\right)}{\pi \Omega \delta_{\text {ave }}^{2}(2 k)}$

$E_{s}=\frac{1}{2} k \delta_{\text {are }}^{2}=\frac{1}{2}$ Pave Save

$\therefore \sum_{\text {eq }}=\frac{E_{D}\left\{\frac{w_{n}}{E_{s}\left\{\frac{4 \pi}{4 \pi}\right\}}\right.}{\text { B.1 }}$ 
EOE INTERNATIONAL

SHEET NO. - 2

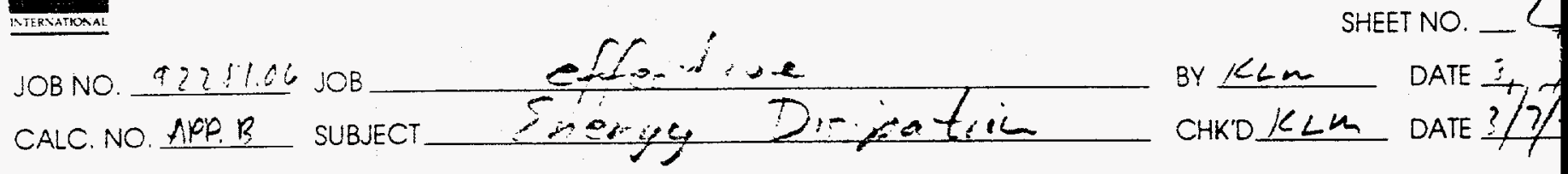

let $\omega_{n}=\Omega$

given for mace Hole REF 46. F165.

$$
\begin{aligned}
& E_{D} \cong 12 \mathrm{k} \cdot \dot{m} @ \delta \text { are }= \pm 1.0 \\
& P_{\text {me }}= \pm 35^{k} \\
& E_{s}=\frac{1}{2} 35 \times 1=17.5 \mathrm{k} \text { i }
\end{aligned}
$$

$$
\sum_{e q}=\frac{12}{17.5} \frac{1}{4 \pi}=.054
$$

for $W_{1}, W_{2}: \operatorname{REF} 16, F_{16} 89$

$$
\begin{aligned}
& E_{D} \simeq 24 @ \delta_{\text {are }}=.75 \mathrm{in} \\
& \text { Pare } \approx 50(5+40 \\
& E_{=}=\frac{i}{2}(50)(75)=18.75 \\
& \Sigma_{e_{1}}=\frac{24}{18.75} \frac{1}{4 \pi}=.102
\end{aligned}
$$

B.2 
APPENDIX $B$

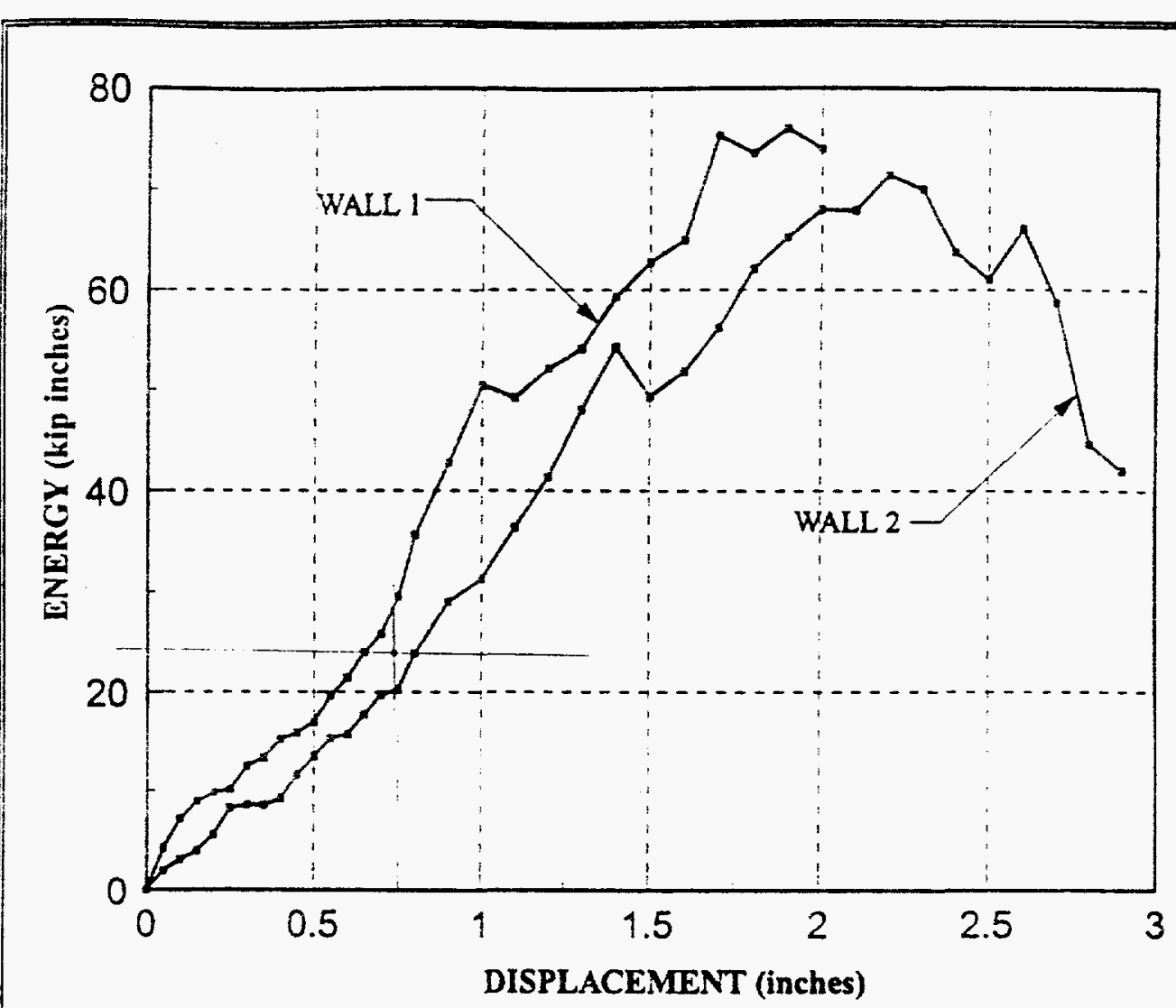

EIGURE 89: ENERGY ABSORBED VS. APPLIED DISPLACEMENT WALLS 1 \& 2)
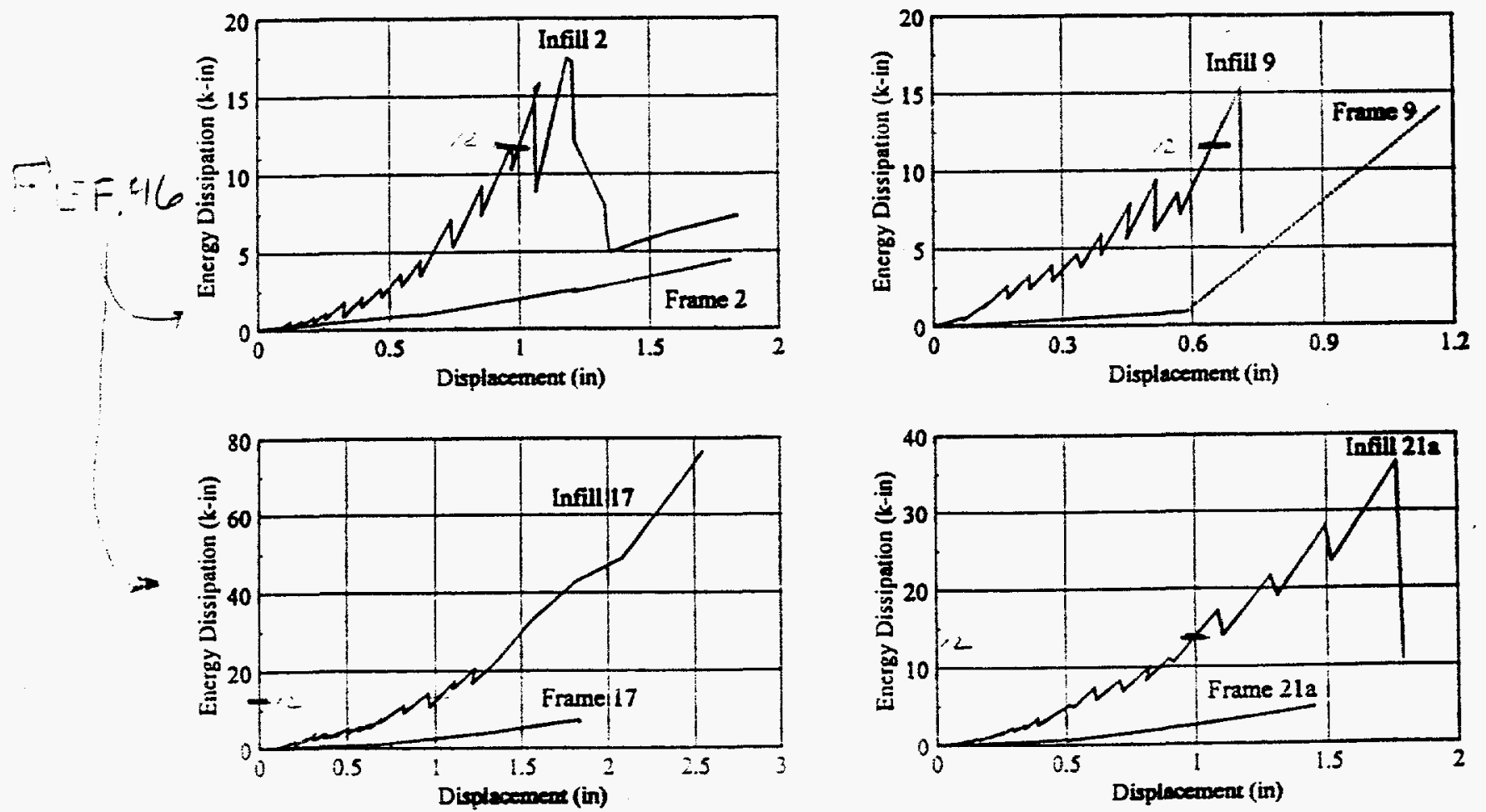

Figure 5.12 Hysteretic Energy Dissipation 
APPENDIX C

EVALUATION OF OUT-OF-PLANE TEST CAPACITY 
EQE INTERNATIONAL

SH

OUT-OE-DLANE BY KLL DATE $2,1 / 9:$ $\mathrm{CHK} \mathrm{D}$ DATE

TEST No

Q/n' motior $\begin{gathered}\text { ifsic } \\ \text { cuber }\end{gathered}$

Ep

f $: 8 \quad 8$

$\therefore \quad 1530$

3.85

0.45

$\begin{array}{llll}1.0 & 1700 & 4.74 & 0.18 \\ 1.0 & 1600 & (5.7) & (2.0) \\ 1.17 & 1.00\end{array}$

"le $\quad z^{\prime \prime}: q^{32.7^{k}=p}$

$1,0 \quad 2: 10 / 2270$

3.15

0.77

$\delta_{2,4}=0.70$

$F_{1} . .231 .2$

in-siter 8"

2.3

$\frac{3.00}{3.25}=.81^{0.6}$

$\frac{z}{201}=04$

$18^{\prime}$ pien $=2428 \quad f_{m}^{\prime}=810 \mathrm{pec}$

$\perp 13$ preen $=1807 \quad f_{n}^{\prime}=332$ peci

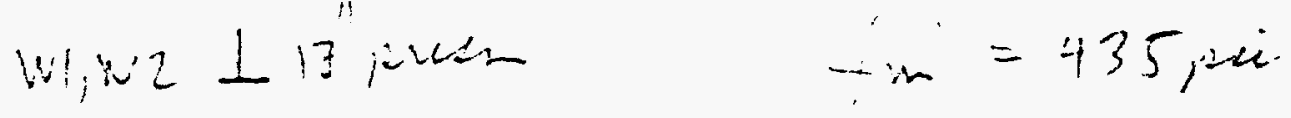

$p+I N$

$\begin{array}{lllll}23 & 1.0 & 1190 & 2.3 & 0.5\end{array}$

$\begin{array}{ccccc}8 & 18 & w 12 \times 35 & 285 & 0.74 \\ 8 & 19 & w / 2 \times 35 & 285 & 0.74 \\ 13 & 22 & w 18 \times 76 & 1330 & 2.83 \\ 4 & 25 & w 12 \times 35 & 285 & 0.74\end{array}$

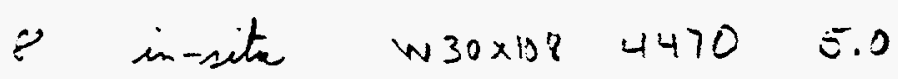

$\begin{array}{lllll}8 & 23 \quad w 12 \times 35 \quad 285 & 0.74\end{array}$

C.1 
SHEET NO. $2 / 5$

JOBNO.922:1.06 JOB OUT-OE-DANE BY 10

DATE ? ? ?

CALI. NO. APP, C SUBLET CHKD DATE

Corder 9207 panel:

$t=7.67(8 \mathrm{nom}) f_{m}^{\prime}=810 \mathrm{pei}$

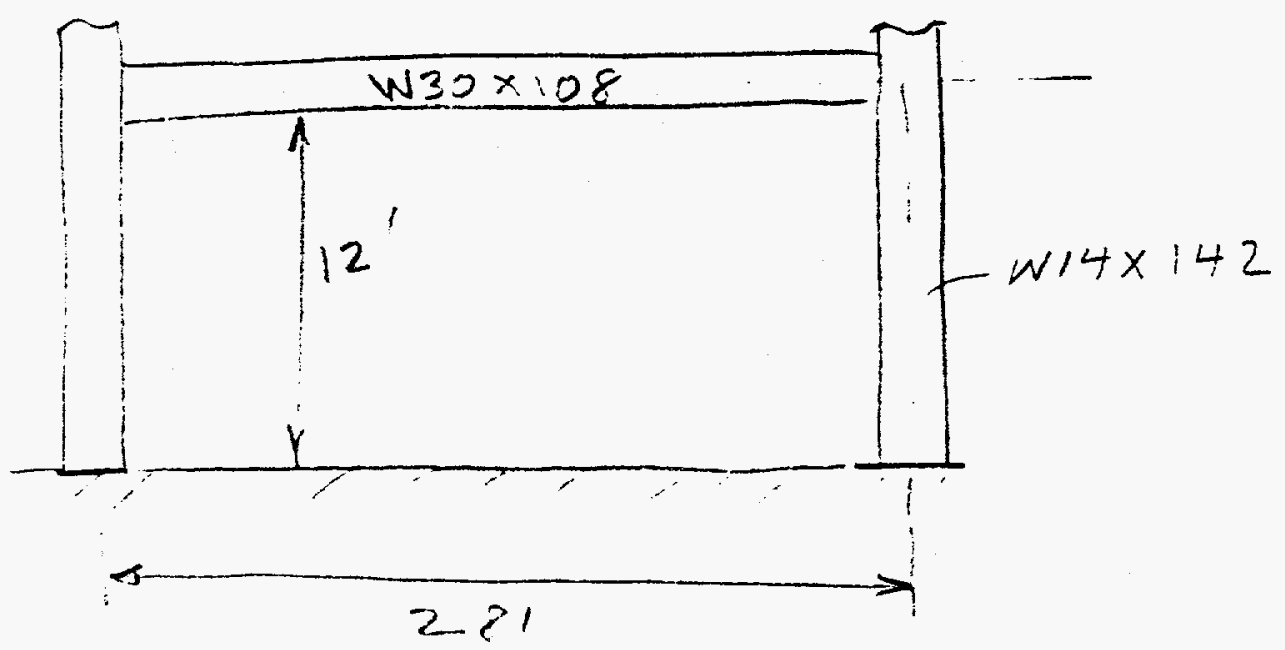

$$
\begin{array}{ll}
1130 \times .02 & E_{0}=E_{x}=4470 \mathrm{in}^{4}, J=5.0 \mathrm{~m}^{4} \\
114 \times 142 & I_{c}=E_{y}=377, \quad J=15.2
\end{array}
$$

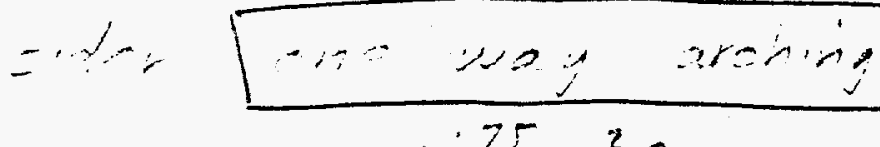

$$
\begin{aligned}
& \begin{array}{l}
q=.8 I_{m} \frac{t^{2} \beta}{h^{\prime 2.5}} \\
e=\frac{1}{l^{\prime}}\left(E I_{b} l^{\prime 2}+G J t l^{\prime}\right)^{\prime / 4}
\end{array} \\
& G=\frac{E}{2.6} \\
& =\frac{1}{28 \times 12}\left(\begin{array}{c}
29 \times 10^{6} \times 4.47 \times 10^{3} \times(28 \times 12)^{2} \\
+\frac{29}{26} \times 10^{6} \times 5 \times 8 \times 28 \times 12
\end{array}\right) \\
& =\frac{1}{2.5 \times 12}\left(14634.71 \times 10^{12}+0.150 \times 10^{12}\right)^{+\frac{29}{2.6} \times 10^{6} \times 5 \times 8 \times 28 \times 12}=\frac{11}{28 \times 12}
\end{aligned}
$$

C. 2 
ERE INTERNATIONAL

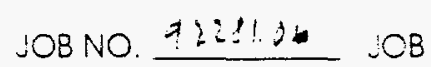

$? \geq 07$

CALC.NO APES SUBJECT

$00 T-0,-0 \angle A N E$
SHEET NO. $\frac{3 / 5}{5}$ BY 1 EL in CHKD

$$
\beta=32.7 \quad-\frac{r}{2}=210
$$

$$
\begin{aligned}
I & =.8(810)^{.75} \frac{8^{2} \times 32.7}{(12 \times 12 ; 2.5} \\
& =.7(151.8) \cdot 00773 \\
& =0.94 \mathrm{puc}
\end{aligned}
$$

TEST LOADING WAS 1.0 PST $=I_{\text {TEST }}$

$$
\frac{Z_{\text {TEST }}}{q}=\frac{1.00}{0.94}=1.00 \quad \frac{h}{t}=\frac{144}{7.67}=18.8
$$

C.3 
JOB NO. $92281.06 \mathrm{JOB}$ OUT-OF-PLANE

CALC. NO APP.C SUBJECT TES $18,19,23$ BY KLH DATE CHK'D DATE

$$
\begin{aligned}
& \text { TEST } 18,19,23 \\
& f_{m}^{\prime}=810 \mathrm{psi} \\
& h^{\prime}=88^{\prime \prime} \\
& l^{\prime}=88^{\prime \prime} \\
& W / 2 \times 35 \quad I_{0}=285 \quad J=0.74
\end{aligned}
$$

consider one-way arching

$$
\begin{aligned}
q & =.8\left(f_{m}^{\prime}\right)^{.75} \frac{t^{2} \beta}{h^{\prime 2.5}} \\
\beta & =\frac{1}{l^{\prime}}\left\{E I_{0} l^{\prime 2}+6 J \pm l^{\prime}\right\}^{1 / 4}, G=\frac{E}{2.6} \\
& =\frac{1}{88}\left\{29 \times 10^{6} \times(88)^{2} \times 285+\frac{29}{2.6} \times 10^{6}(7.67) 88\right\}^{14} \\
& =32.1<\mathrm{K} \\
q & =.8(810)^{.75} \frac{(7.67)^{2}(32.1)}{(88)^{2.5}} \\
& =.8(151.8)(.026) \\
& =3.16 \mathrm{psi}
\end{aligned}
$$

$$
\begin{aligned}
& q_{18}^{\text {TEST }}=3.85 \\
& \frac{q_{\text {EEET.8 }}}{q}=1.22, \quad h_{t}^{\prime}=\frac{88}{7.67}=11.5 \\
& q_{\text {TEST }}=2.3 \\
& \frac{q_{\text {TEST23 }}}{q}=.73 \\
& q_{19}+E S T=3.15 \\
& \frac{q_{T E E T}}{q}=1.0, \quad 1 / t=11.5
\end{aligned}
$$

C. 4 
EOE INTERNATIONAL

SHEET NO. $5 / \sqrt{ }$

JOB NO. 92281.60 JOB OUT-OF-PLANE BY LM DATE $3 / 3 / 45$ CALL. NO SUBJECT TEST 22 CHK'D DATE

$T E S T \quad 22$

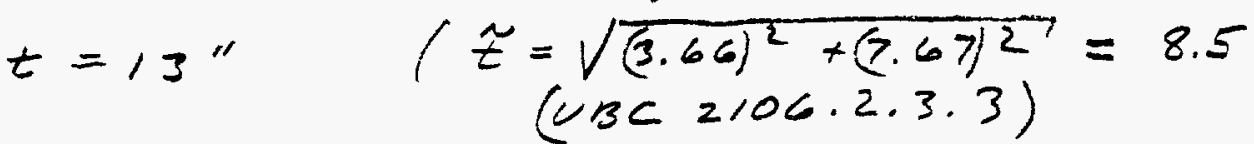

$$
\begin{aligned}
& h^{\prime}=2 l^{\prime \prime} \\
& l^{\prime}=88^{\prime \prime} \\
& I_{b}=1330, \quad J=2.83
\end{aligned}
$$

$$
\begin{aligned}
\beta & =\frac{1}{l^{\prime}}\left\{E I_{0} l^{\prime 2}+G J t l^{\prime}\right\}^{1 / 4}, G=\frac{E}{2.6} \\
& =\frac{1}{88}\left\{29 \times 10^{6} \times(88)^{2} \times 1330+\frac{29}{2.6} \times 10^{6}(13) 88\right\}^{1 / 4} \\
& =47.3>? ?
\end{aligned}
$$

$$
\begin{aligned}
q & =.8\left(\frac{j}{i m}\right)^{.75} \frac{t^{2} \beta}{h^{12.5}} \\
& =.8(332)^{.55} \frac{(13)^{2} 47.3}{(88)^{2.5}} \\
& =.8(77.8)(.110) \\
& =6.85 \text { psi } \\
& =4.74
\end{aligned}
$$

$$
\begin{aligned}
\frac{q_{\text {TEST }}}{q} & =\frac{4.74}{6.85} \\
& =.69 \\
q_{22 \text { TEST }} & =5.7 \\
\frac{q_{\text {TEST }}}{g} & =\frac{5.7}{6.85}=.83
\end{aligned}
$$

C.5 


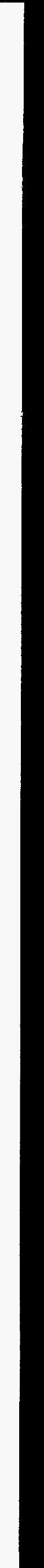


EQE INTERNATIONAL

SHEET NO. $1 / 3$

JOBNO. 92721.06 Tar Taye \& ren BY $1 \mathrm{Ch}$ DATE $3 / 3 / 4 r$ CALC NOAPPC SUBJET Drt-of-plane CHKO DATE

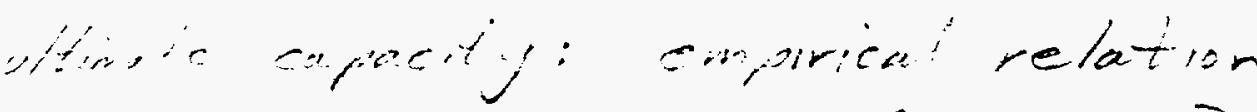

$$
\begin{aligned}
& q_{u, t}=800\left(\frac{1}{\mathrm{~m}}\right)^{0.75} t^{2}\left\{\frac{\alpha}{L^{2.5}}+\frac{\beta}{H^{2.5}}\right\} \\
& \alpha=\frac{i}{H}\left(E I_{C} H^{2}+B T^{2} \pm H\right)^{0.25} \\
& \left.\beta=\frac{1}{L} / E \frac{1}{O} L^{2}+3 \sqrt{B}+L\right)^{0.25} \\
& 2,4 \rightarrow K a \\
& 1 K D_{a}=, 145 \mathrm{pec} \\
& t \rightarrow m \\
& 1 M P a=145 \mathrm{Aec}=.145 \mathrm{ksi} \\
& H, L \rightarrow m m \\
& 16 \mathrm{~Pa}_{a}=145 \times 10^{3} \mathrm{pec} \\
& T_{1} I \rightarrow m m \\
& 29 \times 10^{6} \times \mathrm{He}^{\circ}=29 \times 10^{\circ} \times \frac{M P_{a}}{45} \\
& =200 \times 10^{3} \mathrm{MPa} \\
& N_{m^{2}}=P_{a}
\end{aligned}
$$

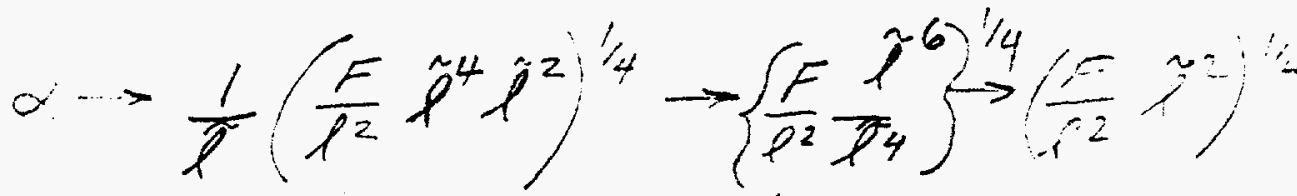

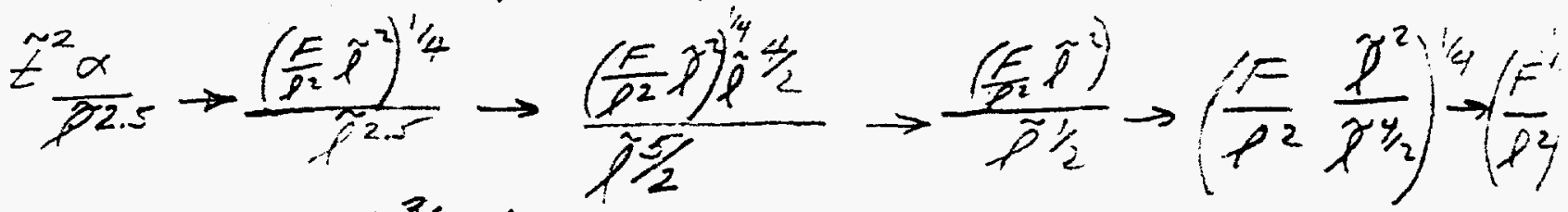

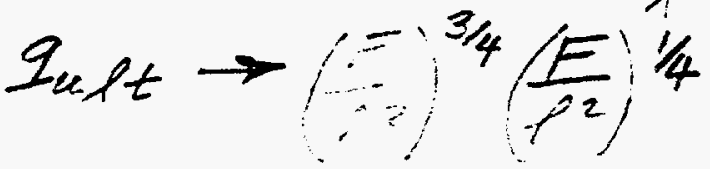

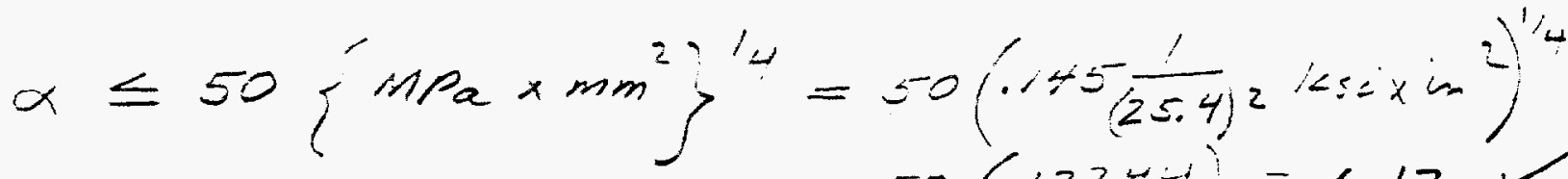

$$
\begin{aligned}
& =50(.22 \cdots)=6.12 \\
& =6.12\left(10^{2} \operatorname{mec} \sin ^{2}\right)^{1 / 4}=34.4
\end{aligned}
$$


EQE INTERNATIONAL

SHEETNO. 2

JOB NO.

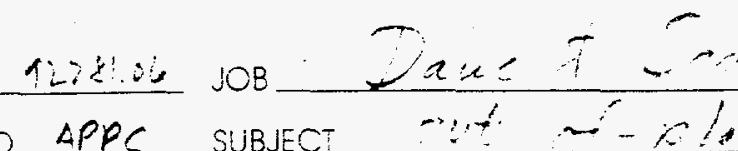

CLn

DATE -

CALC NO. $\triangle P P C$ SUBJEC

CHK'D.

DATE

Example:

$$
\begin{aligned}
& \angle=3600 \\
& \tau=170 \mathrm{~mm} \\
& H=2800
\end{aligned}
$$

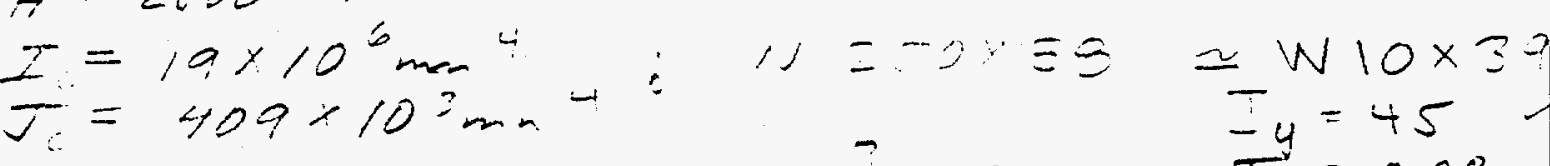

$$
\begin{aligned}
& E=20 \Leftrightarrow 6 P_{a}=200 \% 0^{\circ} \mathrm{APa} \\
& -y=45 \\
& s=77 F_{a}=77 \times 10^{3} \mathrm{Ha}
\end{aligned}
$$

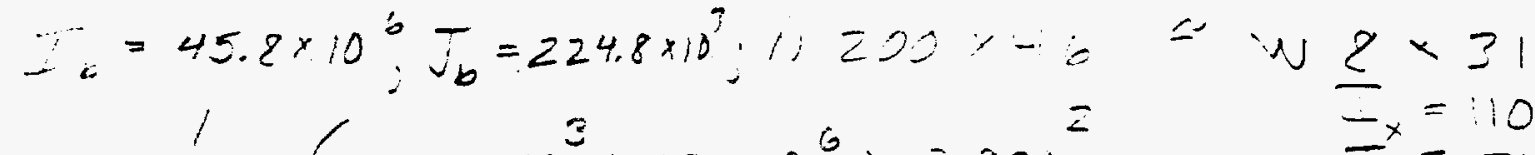

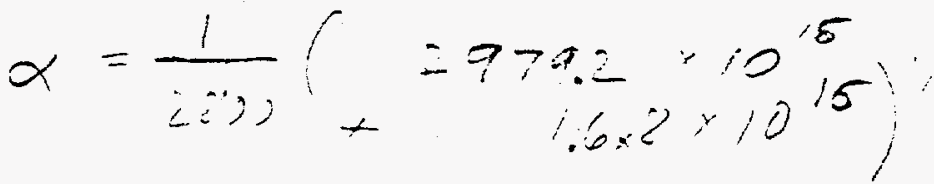

$$
\begin{aligned}
& =26.4 \leq 0 \quad 0<
\end{aligned}
$$

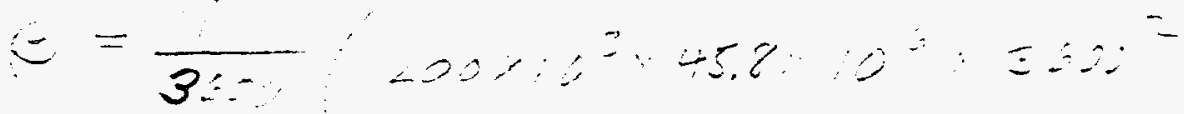

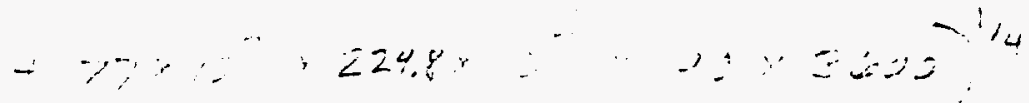

$$
\begin{aligned}
& =\frac{1}{2600}\left(118.71 .4 \times 10^{15}+11 x^{2} \times 10^{16}\right)^{1 / 4} \\
& =29.0 \\
& \begin{aligned}
t^{2}\left(\frac{\alpha}{L^{2.5}}-\frac{\beta}{H^{2.5}}\right) & =(190)^{2}\left(\frac{26.4}{(3600)^{2.5}}+\frac{29.0}{(2800)^{2.5}}\right) \\
& =.00375
\end{aligned}
\end{aligned}
$$

C.8 
EQE INTERNATIONAL

SHEET NO. $3 / 7$

IOBNO. $92281.06 \mathrm{JOB}$

Dawe 7 feas

CALC. NO. APPC SUBJECT
BY $\angle L M$ CHKD

DATE $3 / 3 / 95$ DATE

Example in Dawe Geah poper

is for gap@top.:

$$
\begin{aligned}
q & =800 f_{m}^{\prime 0.75} \frac{t^{2} \alpha}{L^{2.5}} \\
& \frac{t^{2} \alpha}{L^{2.5}}=\frac{(190)^{2} 26.4}{(3600)^{2.5}}=.0012 \\
f_{m}^{\prime} & =\frac{24.3+18.4}{2}=21.4 \mathrm{MPa} \\
q & =9.76 \mathrm{kPa} \sim \text { TEST WEG }_{\text {T }}
\end{aligned}
$$

- if slije@pand columm inteface then one-way arching

$$
\begin{aligned}
& z_{0.1}=800 f_{m}^{1.75} \frac{t^{2} \beta}{H^{2.5}} \\
& =800(21.4 \%(00250)=20.3 \mathrm{kH}
\end{aligned}
$$




\section{INTERNAL DISTRIBUTION}

T. A. Angelelli

D. R. Denton

J. O. Evans

R. D. Flanagan

K. E. Fricke

J. D. Huggins

R. J. Hunt

R. J. Kroon

C. T. McLoughlin

T. L. Ryan

E. G. St. Clair

B. K. Williams

S. R. Wilson

File-KES-RC

Central Files-RC

CNPE Library (10)

EXTERNAL DISTRIBUTION

Office of Scientific and Technical Information (2),

U. S. Department of Energy, Oak Ridge Field Office

Chief of Y-12 ES \& H Branch (3),

U. S. Department of Energy, Oak Ridge Field Office

Gilbert Commonwealth, Inc. (3),

Oak Ridge, Tennessee

M. S. Technology, Inc.,

Oak Ridge, Tennessee 